The Russian Academy of Natural History

Publishing House of the Academy of Natural Sciences

\author{
Amankul Akbasova, Gauhar Sainova
}

\title{
GROWTH STIMULANT AGENTS AND BACTERICIDES
}

Monograph

\author{
Рекомендовано УМО РАЕ \\ по классическому университетскому \\ и техническому образованию в качестве \\ учебного пособия для студентов \\ высших учебных заведений, \\ обучающихся по специальности \\ 030016 - «Экология»
}


UDC 574.5: 502/504(038)

\section{A38}

The monograph was prepared with the financial support of the Ministry of Education and Science of the Republic of Kazakhstan. (Grant projects № 195, № 173).

It is recommended to publish by the decision of the Senate of A. Yasawi International Kazakh-Turkish University (Minutes № 1 dated September 18.2015).

\section{Reviewers:}

Galymzhan Elikbayev - Doctor of Medical Sciences, professor; Esbol Zhamalbekov -Doctor of Agricultural Sciences, professor

A38 Growth stimulant agents and bactericides: monograph / Amankul Akbasova, Gauhar Sainova. - M.: Publishing House of the Academy of Natural Sciences, 2015. - 120 p.

ISBN 978-5-91327-358-1

DOI 10.17513/np.132

The book presents materials on the waste produced in the course of human activities, covering the issues of waste storage, waste formation, treatment and disposal of waste to produce commercial products. Special focus was on the search and expansion of using industrial waste of one production as raw material for another production. Using industrial-related sulfur-containing wastes as raw material, a series of effective environmental technologies was developed by authors for the synthesis of various inorganic ammonium salts (persulfate, hydrosulphate, sulphate, thiosulphate, etc.) and organic heterocyclic compounds (piperidine derivatives). It was obtained previously unexplored bioactive compounds from the utilizing products of industrial waste, namely new disinfectants, growth stimulants and development of vegetable and cereal crops and also the ways of their implementation was established. The book is intended for a wide range of scientific, pedagogical workers, bachelors, masters, doctoral and for farsighted representatives of business.

ISBN 978-5-91327-358-1

(C) Akbasova A., Sainova G., 2015

(C) ИД «Академия Естествознания»

(C) MOO «Академия Естествознания» 


\section{CONTENT}

INTRODUCTION 5

1. PRODUCTION WASTES AS POTENTIAL SOURCE

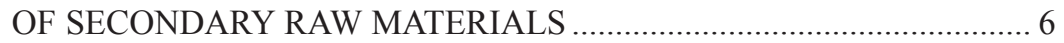

1.1. Characteristics of wastes and field of their use.................................. 6

2. PROCESS METHODS OF UTILIZATION

OF THE OIL AND GAS INDUSTRY SULFUR CONTAINING WASTES WITH PRODUCTION OF BACTERICIDES AND FERTILIZES

2.1. Methods for production of ammonium salts and their properties

2.2. Physical and chemical properties of bactericide synthesized on the basis of ammonium persulfate and bisulfate produced from sulfur containing wastes

2.3. Decontamination of animal residues contaminated by infectious agents

3. PRODUCTION WASTE BIOACTIVE SUBSTANCES AND THEIR USAGE

3.1. Characteristics of growth-stimulating substances, methods of their production

3.2. Sinthesis of biologically active compounds of piperidine series from production wastes and usage of these compounds for environmental improvement.

3.3. Antibacterial activity and toxicity of preparations based on the new piperidine derivatives

4. APPLICATION OF BIOLOGICALLY

PREPARATIONS ALT-6, ALT-7, ALT-S IN AGRICULTURE 73

4.1. Impact of growth stimulants ALT-6, ALT-7, ALT-S on the crop and quality of potatoes

4.2. Piperidine derivatives ALT-6, ALT-7, ALT-S as new growth stimulants and stress protectors for winter wheat. 
4.3. Impact of ALT-6, ALT-7, ALT-S preparations on growth and development of radish.

4.4. Impact of ALT-6, ALT-7, ALT-S preparations on growth and development of beetroot and carrot

4.5. Impact of the growth stimulating piperidine derivatives ALT-6, ALT-7, ALT-S on growth and resistance of corn and mustard to temperature fluctuations and dehydration 101

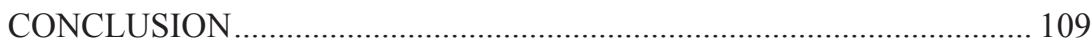

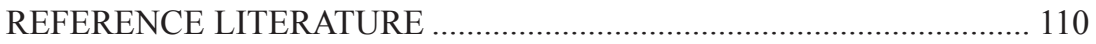




\section{INTRODUCTION}

Environment protection and rational use of natural resources through the development and implementation of resource-saving and low-waste technologies are the priorities of environmental policy today. Therefore in recent years, we have intensified work to develop new technologies to recycle industrial and domestic waste to produce either marketable end product or their transformed form, suitable for use as raw materials for certain manufacturing process of various industries including the chemical industry.

Experience to date has shown that the use of man-made wastes as raw materials is one of the most efficient methods for their recycle. On one side this approach can reduce the impact on the environment, on other side it ensures more sustainable utilization of scarce and non-renewable natural resources replacing primary raw material to the secondary ones.

Research of interest at this time is aimed to develop effective clean technologies for synthesis of new organic and inorganic chemical compounds by using industrial wastes as a raw material.

In this paper, we focus on searching for the most advanced ways to dispose of sulfur-containing waste from the gas industry and aldehyde containing waste from the chemical industry as a secondary raw material. Studies carried out in two ways:

1) synthesis of new biologically active piper dine derivatives which have high growth promoting activity for the growth and development of agricultural crop;

2) preparation of various inorganic sulfur compounds (sulfates, persulfates, thiosulfates, hydrogen, etc.) and develop on this basis new disinfectant formulations for treatment facilities, animal production units with tuberculosis, brucellosis concern and for treating necrobacillosis and other diseases of small ruminants and cattle.

The following resources were used when writing this book: works of foreign and domestic scientists published in various publications and in source book of scientific and technical conference, scientific and technical literature, encyclopedia, Internet resources, public standards, guidelines and standards of international organizations. The main results were published earlier in [1-26]. 


\section{PRODUCTION WASTES AS POTENTIAL SOURCE OF SECONDARY RAW MATERIALS}

\subsection{Characteristics of wastes and field of their use}

Currently, the disposal of waste is among the major problem in all countries. Of 120 billion tons of the substance used in the production and consumption, about 9 billion tons are converted into tangible products and the rest is returned to the environment as waste products [1,27]. In this regard, the amount of harmful substances coming from anthropogenic sources and their concentration exceed safe level. Current situation in many areas is real risk to all biota including public health.

According to global experience, the best solution to the problem of waste management is the rational use of industrial, domestic and other wastes as secondary raw material. Under this approach, it is possible to solve a range of issues against environmental protection, saving primary materials, electricity and releasing manpower.

Most industrial wastes are valuable materials if they are used wisely, which is clearly seen from Table 1.1 .

Table 1.1 clearly shows that many substances and materials related to waste, in actual fact we can re-enable the economic cycle or use them as raw material for other industries, or make useless things useful to meet different needs. Solving waste disposal problem is also gives opportunity to free up a lot of land for agriculture use [28].

With each passing year, due to growth of industrial production, global stocks of raw materials are being sharply reduced. According to scientists estimate, oil and gas reserves at current value will be enough only for 80 170 years, stocks of zink, nickel, copper for 100 years, coal deposits can be developed even 1,700 years. Especially mineral reserves are greatly reduced. Since natural resources are not unlimited, it is necessary to focus on integrated use of them, that is the creation non-waste technologies and increase raw materials base through extensive use of waste in the various sectors of economy. It is mostly extracted only $2-3 \%$ of useful elements from mineral ore In Nonferrous industry and $97-98 \%$ go to waste.

About $80 \%$ of wastes from heat and power, mining, chemical-recovery industries are fit to recycle. In addition, the products produced often exceeds 
in quality than products made from raw materials. Ash and slag represent a significant raw material potential among these wastes. Currently, 20\% of this valuable material is being processed. Mostly ash is used as filler for cement. Thus, for example 1,3 tons of ash from brown coal, captured from smokestack exhaust gases, replace 1 ton of cement. In order to obtain stronger building panels and blocks, it is recommended to use ash from thermal power station as an additive in the production of aerated concrete. A composition of brown coal ash (5-30\% iron oxide, 30\% lime, and appreciable amounts of residual coal coked) shows the possibility of its use in metallurgy industry to produce iron concentrate [29].

Table 1.1

Waste generating sources and their field of use

\begin{tabular}{|c|c|}
\hline Type and composition of waste & Field of use \\
\hline 1 & 2 \\
\hline \multicolumn{2}{|r|}{ Mineral resource industry } \\
\hline \multicolumn{2}{|r|}{ a) coal } \\
\hline $\begin{array}{l}\text { Crushed stone, limestone, } \\
\text { sand, clay, chalk, slag } \\
\text { heaps - mining waste }\end{array}$ & $\begin{array}{l}\text { In the production of building materials } \\
\text { During construction of highway to raise traffic- } \\
\text { bearing surface }\end{array}$ \\
\hline \multicolumn{2}{|r|}{ b) enriching factory } \\
\hline Ash, slag & $\begin{array}{l}\text { In the production of agloporite - porous concrete } \\
\text { aggregate as lightweight concrete aggregate, in the } \\
\text { production of expanded clay as a binder it is added to } \\
\text { plaster and mortar }\end{array}$ \\
\hline \multicolumn{2}{|c|}{ Oil production and oil refining } \\
\hline Hydrogen Sulphide $\mathrm{H}_{2} \mathrm{~S}$ & Sulfur, sulfur-containing compound \\
\hline Sulfur & $\begin{array}{l}\text { For the synthesis of organic and inorganic sulfur- } \\
\text { containing compound, bactericidial and growth } \\
\text { promoting preparations, fertilizers, sulfur concrete, in } \\
\text { the production of rubber }\end{array}$ \\
\hline \multicolumn{2}{|r|}{ Ferrous metal industry } \\
\hline $\begin{array}{l}\mathrm{Slag}-\mathrm{CuO}, \mathrm{SiO}_{2}, \mathrm{Al}_{2} \mathrm{O}_{3}, \\
\mathrm{MgO}, \mathrm{Fe}_{2} \mathrm{O}_{3}, \mathrm{MnO}_{2} \mathrm{TiO}_{2}, \\
\text { sulfides, chromium and ura- } \\
\text { nium compound }\end{array}$ & $\begin{array}{l}\text { For the production of slag glass-ceramic which goes } \\
\text { to manufacture extrastrong and chemically resistant } \\
\text { pipe, panels, electrical insulators and vacuum-tube } \\
\text { devices }\end{array}$ \\
\hline Blast-furnace slag & $\begin{array}{l}\text { In the industry of construction materials - cement, } \\
\text { slag, crushed stone, slag pumice, mineral wool }\end{array}$ \\
\hline
\end{tabular}


Continuation of table table 1.1

\begin{tabular}{|c|c|}
\hline Type and composition of waste & Field of use \\
\hline 1 & 2 \\
\hline Steelmaking slags & $\begin{array}{l}\text { Fertilizer, in the road construction as a substitute for } \\
\text { crushed stone materials, as fluxing agent in blast- } \\
\text { furnace ironmaking and casthouse production }\end{array}$ \\
\hline Blast furnace gas & $\begin{array}{l}\text { For producing of phosphate fertilizers } \\
\text { As fuel (calorific value } 3,0-10,0 \mathrm{MJ} / \mathrm{m}^{3} \text { ) }\end{array}$ \\
\hline Iron-containing wastes & In Ceramic Manufacturing \\
\hline \multicolumn{2}{|r|}{ Nonferrous-metals industry } \\
\hline Pyritic cinders & $\begin{array}{l}\text { To improve roasting process and improving the qual- } \\
\text { ity of cement }\end{array}$ \\
\hline Slag & $\begin{array}{l}\text { Construction industry, producing nanomodifiers of } \\
\text { concrete, cement, abrasive }\end{array}$ \\
\hline Battrery scrap & To produce hard lead \\
\hline Exhausted sour gas & $\begin{array}{l}\text { Sulfuric acid for the synthesis of sulfur-containing } \\
\text { compound }\end{array}$ \\
\hline Cleaning Sulfuric Acid & To produce bactericidal preparation, fertilizers \\
\hline $\begin{array}{l}\text { Titan-magnesuim production } \\
\text { cakes }\end{array}$ & $\begin{array}{l}\text { For production of construction materials - bricks, } \\
\text { wall ceramics. For backfilling of mining excavations }\end{array}$ \\
\hline $\begin{array}{l}\text { Cakes and Chlorine-contain- } \\
\text { ing waste }\end{array}$ & $\begin{array}{l}\text { In the production of portland cement clinker. As } \\
\text { a coagulant for the treatment and dewatering of sew- } \\
\text { age sludge treatment plant }\end{array}$ \\
\hline Magnesium-containing & Production of magnesia cement \\
\hline Arsenic-containing & To produce antisepticpreparation in wood production \\
\hline $\begin{array}{l}\text { Residues from sludge } \\
\text { collector }\end{array}$ & $\begin{array}{l}\text { As an additive for cement-concrete, gypsum concrete } \\
\text { mixture and ceramic materials }\end{array}$ \\
\hline $\begin{array}{l}\text { Liquid organo-mineral } \\
\text { prompt of industrial scrap }\end{array}$ & $\begin{array}{l}\text { In the production of expanded clay gravel for clay } \\
\text { swelling (replacement for diesel) }\end{array}$ \\
\hline Dump sludges & For metal concentrates \\
\hline \multicolumn{2}{|r|}{ Chemical Process Industry } \\
\hline \multicolumn{2}{|r|}{ a) alumina production } \\
\hline $\begin{array}{l}\text { Red mud }-50 \% \mathrm{Fe}_{2} \mathrm{O}_{3} \\
\text { и } \mathrm{SiO}_{2}, \mathrm{Al}_{2} \mathrm{O}_{3}, \mathrm{Na}_{2} \mathrm{O}, \mathrm{CaO} \\
\mathrm{MgO}, \mathrm{TiO}_{2}, \mathrm{~K}_{2} \mathrm{O}\end{array}$ & $\begin{array}{l}\text { Ferrous metal industry, construction materials } \\
\text { industry - as a filler for concrete, bitumen,cement, } \\
\text { for the manufacture of bricks, ceramic materials; for } \\
\text { purification of waste water }\end{array}$ \\
\hline \multicolumn{2}{|r|}{ b) fertilizer manufacturing } \\
\hline $\begin{array}{l}\text { Phosphogypsum } \\
\left(92-96 \% \mathrm{CaSO}_{4}\right)\end{array}$ & $\begin{array}{l}\text { For the production of portland cement; } \\
\text { Activated lime is used for preparing of masonry and } \\
\text { plaster mortar in Paper industry instead of kaolin }\end{array}$ \\
\hline
\end{tabular}


Continuation of table table 1.1

\begin{tabular}{|c|c|}
\hline Type and composition of waste & Field of use \\
\hline 1 & 2 \\
\hline Ffluorine containing - gas & $\begin{array}{l}\text { In agriculture for reclamation of acidic soil; } \\
\text { for the production of sufur acid, lime; for the production } \\
\text { of aluminuim fluoride and other metals, sodium silicon } \\
\text { fluoride and potassium ( } \mathrm{NaF} \text { - antiseptic, } \mathrm{HF}, \mathrm{BaF} 2- \\
\text { insecticide, flourides used in glassmaking,fermentation } \\
\text { process, in the production of enamels) }\end{array}$ \\
\hline \multicolumn{2}{|r|}{ c) phosphorus production } \\
\hline Phosphorus slag & $\begin{array}{l}\text { For the production of slag crushed stone, slag wool, } \\
\text { slag pumice, slag glass-ceramic,finishing materials, } \\
\text { facing tile with glazed surface, slag portland-cement }\end{array}$ \\
\hline \multicolumn{2}{|c|}{ d) Sodium carbonate production } \\
\hline Slag & For the production of binding material \\
\hline Calcium chloride & $\begin{array}{l}\text { For the treatment of pyrite cinder, waste sulfuric acid } \\
\text { production to produce raw material for ferrous and } \\
\text { non-ferrous metallurgy }\end{array}$ \\
\hline \multicolumn{2}{|r|}{ e) coke and by-product process } \\
\hline $\begin{array}{l}\text { Coal-tar asphalt, tar and other } \\
\text { wastes }\end{array}$ & $\begin{array}{l}\text { To produce tar (it is poured to road before asphalt- } \\
\text { ing) and other products used for the production of } \\
\text { synthetic rubber, colorant, plastics. As an anti-corro- } \\
\text { sion inhibitor }\end{array}$ \\
\hline Oil & Benzol, xylene, naphthalene \\
\hline Hydrogen Sulphide $\mathrm{H}_{2} \mathrm{~S}$ & $\begin{array}{l}\text { For the production of sulfide and ammonia polysul- } \\
\text { phide which are insectofungicide }\end{array}$ \\
\hline Coke gas & $\begin{array}{l}\text { As a fuel (calorific value of a combustible } \\
17,2-18,8 \mathrm{~mJ} / \mathrm{m}^{3} \text { ) }\end{array}$ \\
\hline \multicolumn{2}{|c|}{ f) production of capron, foamed polystyrene and other polymers } \\
\hline Wastes & As a rust inhibitor \\
\hline & g) chlorine production \\
\hline $\begin{array}{l}\text { Exaust gases containing } \\
\text { chlorine }\end{array}$ & $\begin{array}{l}\text { Didposing with sulphurous anhydride, produce delute } \\
\text { salt acid }\end{array}$ \\
\hline \multicolumn{2}{|r|}{ TPS, CHP plant } \\
\hline Ash & $\begin{array}{l}\text { For coal pit backfilling to restore the land surface } \\
\text { disturbed by open-pit mining.In Canada industrial } \\
\text { unit was developed for integrated processing of ash } \\
\text { to produce the following products: thin synthetic rub- } \\
\text { ber, colorant, plastics. }\end{array}$ \\
\hline Fuel-oil ash (7-15\% vanadium) & For extraction of vanadium \\
\hline
\end{tabular}


Continuation of table table 1.1

\begin{tabular}{|c|c|}
\hline Type and composition of waste & Field of use \\
\hline 1 & 2 \\
\hline Lumpy slag & $\begin{array}{l}\text { As concrete aggregate in road construction and in fill } \\
\text { insulation }\end{array}$ \\
\hline Ash and slags & $\begin{array}{l}\text { As fine aggregate for the production of reinforced } \\
\text { concrete structure from ceramist }\end{array}$ \\
\hline Slags and loose ashes & $\begin{array}{l}\text { For the production of aerated concrete construction } \\
\text { products (light blocks) autoclaved silicate building } \\
\text { product, fly ash aggregate }\end{array}$ \\
\hline Oil shale ash & $\begin{array}{l}\text { For the production of ground base for auto road and } \\
\text { airfields }\end{array}$ \\
\hline Gold dumps & For sowing forage grasses \\
\hline Ash and slags & $\begin{array}{l}\text { Construction material - azurite (used as a filler for } \\
\text { concrete and as a thermal insulator) }\end{array}$ \\
\hline $\begin{array}{l}\text { Ekibastus coal ash }(55-60 \% \\
\left.\mathrm{SiO}_{2}, 23-25 \% \mathrm{Al}_{2} \mathrm{O}_{3}\right)\end{array}$ & For aluminum production \\
\hline $\begin{array}{l}\text { Brown coal ash }\left(25 \% \mathrm{Al}_{2} \mathrm{O}_{3}\right. \\
\left.40 \% \mathrm{SiO}_{2}, 9 \% \mathrm{Fe}_{2} \mathrm{O}_{3}\right)\end{array}$ & $\begin{array}{l}\text { For the production of calcium monoaluminate by } \\
\text { sintering with limestone }\end{array}$ \\
\hline \multicolumn{2}{|r|}{ Transport Industry } \\
\hline Auto-tyre & $\begin{array}{l}\text { It is added to road surface in a mixture with stone } \\
\text { coal,; in the production of carpeting (covering) for } \\
\text { sport facilities and other rubber products (mats,pedal } \\
\text { covers, car shock absorbers); for the production of } \\
\text { traffic signs (rubber is crushed, then it is mixed with } \\
\text { technical sulfur and then it is heated and pressed, } \\
\text { finally light reflecting symbol is stuck on light, } \\
\text { chemical-resistant mixture produced) }\end{array}$ \\
\hline Old asphalt & $\begin{array}{l}\text { It is regenerated by adding } 30-40 \mathrm{~kg} \text { of bitumen for } \\
150 \mathrm{~kg} \text { of old asphalt concrete. Produced mixture is } \\
\text { used for new roadway covering }\end{array}$ \\
\hline $\begin{array}{l}\text { Salvaged vehicles and ma- } \\
\text { chineries }\end{array}$ & For the production of metals \\
\hline \multicolumn{2}{|r|}{ Woodworking Industry } \\
\hline $\begin{array}{l}\text { Wood chips, sawdust, shav- } \\
\text { ing and other lumber waste, } \\
\text { wood waste }\end{array}$ & $\begin{array}{l}\text { As a fuel in original form and after conversion to } \\
\text { combustible gas in gasification reactor (calorific } \\
\text { value } 1600-1700 \mathrm{Kcal} / \mathrm{m}^{3} \text { ); in the manufacture of } \\
\text { furniture and other extruded products }\end{array}$ \\
\hline
\end{tabular}


Continuation of table table 1.1

\begin{tabular}{|c|c|}
\hline Type and composition of waste & Field of use \\
\hline 1 & 2 \\
\hline Bark & $\begin{array}{l}\text { For the production of compost and others. Ferti- } \\
\text { lizer, insulation and hardboard, various construction } \\
\text { materials }\end{array}$ \\
\hline Untreated bark of conifers & $\begin{array}{l}\text { As an insulation material in the construction of } \\
\text { railways and roads to protect them from freezing (a } \\
\text { layer of bark } 40 \mathrm{~cm} \text { thick has the same insulating } \\
\text { effect as gravel layer thickness of } 1,3 \mathrm{~m} \text { ) }\end{array}$ \\
\hline \multicolumn{2}{|r|}{ Light Industry } \\
\hline Leather waste & For fertilizers, feed additives, leather glue, industrial fat \\
\hline Collagen waste & $\begin{array}{l}\text { In medicine and in veterinary medicine in the form } \\
\text { of films, sponges and ointments for the treatment of } \\
\text { various eye diseases, wounds, burns, as a hemostatic } \\
\text { agent in the food industry for the preparation of fat } \\
\text { substitutes, albumin, sausage casings, as a flocculent } \\
\text { it is added to drinks }\end{array}$ \\
\hline Lanolin (wool grease) & $\begin{array}{l}\text { As a valuable raw material in Medical and Perfume } \\
\text { Industry }\end{array}$ \\
\hline Tannery wastewater & $\begin{array}{l}\text { Produce compost from sludge obtained during } \\
\text { purifying }\end{array}$ \\
\hline \multicolumn{2}{|r|}{ Printing Industry } \\
\hline Paper waste & $\begin{array}{l}\text { For the production of paper and foam tubes, wall } \\
\text { plate materials; printing paper; food packaging paper }\end{array}$ \\
\hline \multicolumn{2}{|r|}{ Public Utilities } \\
\hline Metal scrap & For the production of metal \\
\hline Glass waste & $\begin{array}{l}\text { In the production of glass containers, building ceram- } \\
\text { ics, glass decorative concrete block, porous aggre- } \\
\text { gate, thermal insulation materials }\end{array}$ \\
\hline Solid wastes & $\begin{array}{l}\text { To produce electrical or thermal energy based on } \\
\text { high temperature pyrolysis }\end{array}$ \\
\hline \multicolumn{2}{|r|}{ Agricultural Industry } \\
\hline Cotton stalks, paddy straw & $\begin{array}{l}\text { As a filler in the production of lightweight ceramsite } \\
\text { concrete }\end{array}$ \\
\hline Cotton stalks & $\begin{array}{l}\text { For the production of paper, cardboard, building } \\
\text { boards, fodder yeast, and about } 200 \text { types of chemicals }\end{array}$ \\
\hline $\begin{array}{l}\text { Animal manure and manure } \\
\text { runoff }\end{array}$ & $\begin{array}{l}\text { Recycles into fertilizer, used to produce energy, protein } \\
\text { drug, biogas, hydrogen, motor fuel, carbon dioxide gas }\end{array}$ \\
\hline
\end{tabular}


Continuation of table table 1.1

\begin{tabular}{|l|l|}
\hline Type and composition of waste & \multicolumn{1}{c|}{ Field of use } \\
\hline \multicolumn{1}{|c|}{1} & \multicolumn{1}{c|}{2} \\
\hline Poultry manure & $\begin{array}{l}\text { For the production of combustible gases and liquid } \\
\text { diesel fuel, as fertilizer, feed, adding to a psychotrop- } \\
\text { ic product to produce naswar }\end{array}$ \\
\hline Saccharified residues & $\begin{array}{l}\text { For the production of ethanol as a fertilizer, feed ad- } \\
\text { ditives, sorbents to create geochemical barriers }\end{array}$ \\
\hline
\end{tabular}

Raw materials resource base of Kazakhstan Nonferrous-Metals Industry successfully strengthened through wider use of not only ash, but also use hundreds of millions of tons of slags accumulated over many years, in which a number of metal content is significantly higher than ore mined. Prime cost of metal extracted from slag is several times lower than obtained from the ores, as it does not require geologic exploration, transportation, construction of mines and enriching factory [30].

The exhaust gases from a lot of non-ferrous and ferrous metallurgy used as raw materials for the production of sulfuric acid. The method of utilization is based on acid catalytic oxidation of sulfur oxide in sulfuric acid solution in the presence of a catalyst:

$$
2 \mathrm{SO}_{2}+\mathrm{O}_{2}+2 \mathrm{H}_{2} \mathrm{O} \rightarrow 2 \mathrm{H}_{2} \mathrm{SO}_{4} .
$$

Vanadium oxide $(\mathrm{V})$ or divalent manganese salt is used as a catalyst. Prime cost of acid obtained by utilization of sulfur-containing gases in Iron and Steel Company and also estimated capital investment for 1 ton product is 2 times lower than to produce sulfuric acid from natural raw materials.

In Kazakhstan, on the basis of using metallurgical wastes for the purpose of multiple uses of ore raw materials, there is being developed by the Chemical Industry production of nitrogen, phosphate and other mineral fertilizers. Wastes obtained during production of oxygen in Iron and Steel Company are used for the production of nitrogen fertilizers. Sulfuric acid obtained from flue gases, generated during roasting of sulfide ores is used to produce superphosphate, sulfate, hydrosulfate, persulfate, ammonium thiosulfate and other salts.

The metal scrap is of considerable interest among industrial wastes. The total amount of junk for a portion of metal scrap in bulk, powder form, chips generated during production processes is 67 and $31 \%$ - is dormant scrap, remaining $2 \%$ - is the metals extracted from slag dump [31]. 
The sources of dormant scrap are written off and worn equipment's, tools, products, inventory, etc. For example, average life duration of wagon and rail about 30 years, ships -25 years, brigs -100 years, power lines -50 years, automobiles -10 years [31].

In machine-building enterprises, $55 \%$ of dormant scrap generated during replacement of production accessories and processing tools. Quantity of metal waste in production depends on the amount of metals alloys to be processed. Wastes are generated during rolling, casting and machining process and the main source of waste generation is metalworking [31].

Iron and Steel Companies are not only sources of scrap and waste metal, but also their main customers. For the production of electric steel, it is used up to $940 \mathrm{~kg}$ /ton of junk, upto $500 \mathrm{~kg} /$ ton of Martin steel, from 20 to $700 \mathrm{~kg} / \mathrm{ton}$ of cast iron. The steel produced from metal scrap is $60-70 \%$ cheaper than produced from ores $[31,32]$.

Special attention is paid to the collection and recycling of aluminum and tin cans in many countries. The first product has been subjected to general processing were aluminuim cans in the United States. In 1990, it was produced 88 billion of cans and 55 billion of them recycled ones which is $62,5 \%$. Amount of recycled aluminum and tin cans in the UK is no more than $5 \%$, in Western Europe $-25 \%$. In the future, it is expected to increase the amount of recycled cans, since it is required only to use $1 / 10$ of the energy to obtain aluminum from these wastes which would spent on the production of cans from original raw material, in other words recycling is beneficial economically [30].

Recycling and reuse of plastics and other polymer materials are extremely difficult and at the same time immediate issues. These issues are partly solved, since their processing requires careful preliminary sorting and identification. Then they are crushed, washed, separated and then used to produce a specific product. Mixed plastics which have not exact characteristics are used in the production of low grade materials. Some products made of polyurethane and synthetic fibers are processed very hardly, they are not biodegradable when they are buried and so there is an existing problem with plastic wastes. Annually, around the world more than 80 million tons of plastic, more than $70 \%$ of these materials enter the waste stream in the form of food containers and car batteries.

During the last 15-20 years there has been intensively conducted research works on the creation of the second-generation plastics. Usual cheap plastics made from petroleum are being replaced to biopolymers, which are dissolved to environmentally safe compound under the influence of microorganism. 
These new materials obtained on the base of polymerization of starch and cellulose mixture separated from agricultural plant (corn, potato, solid waste) and polyethylene. Biodegrable synthetic polymers include also polyesters obtained by chemical synthesis and biopolymers, bio saccharides synthesized by microorganisms. They are fully biodegradable in the presence of moisture and are composting under different condition. There have been already received a number of products on the basis of biopolymers: wood wool which previously was made of polystyrene, packing bags, a variety of disposable tableware, containers, etc [33, 34].

Scientific and Manufacturing Association "Norplast" was established in Moscow which is developing new materials based on polymers. In order to to save raw material - oil, portion of polymer is replaced by natural fillers, inorganic compounds or industrial waste such as cotton linters, processed grape wastes, lignine which are easily dyed in any color and metallized. These materials are used for the production of pipe, containers of household chemicals, parts for electrochemical industry and various consumer goods. Garbage bags, household bucket, gaskets are produced from the high-pressure polyethylene waste and plumbing parts, door handles, boxes for plants and others produced from polypropylene waste $[35,36]$.

Plastic wastes are often used without recycling in varous sectors of economy. For example, wastes of synthetic fibre: lavsan, nitrone, nylon and nonwoven materials: polyvinyl chloride, foam urethane is used as absorbent in purification of waste water; bitumen used in road asphalting or in combination with polyolefin to obtain modified coatings.

The most valuable material is wastes from woodworking industries and paper industries. Wood waste (bark, chips, sawdust and etc) is used to produce energy or heat. They burn best if they are mixed with liquid fuel. Sawdust is also used for industrial needs as an additive to raw brick to reduce its drying process [37].

In many countries, much attention is paid to the processing of waste paper for the production of writing, printing paper, non-flammable paper, paper pulp, etc. For example, it is obtained about $44 \%$ of all used paper (collected annually: 2,8 mln.ton) from recycled paper in Germany which saves from cutting $40 \mathrm{mln}$ trees every year. Also, it requires for $60 \%$ less energy for recycling of waste paper than for producing paper from wood. It reduces atmospheric pollution to $85 \%$ and water pollution to $60 \%$ [38].

In wool-washing subsector of light industry, there is formed wool grease (its chemical name is lanolin) during primary processing of wool and which is a valuable raw material in medical and perfume industries. 
Sugar Refinery refers to the non-waste industry which is associated with using their wastes as material for other industries.

The main sugar plants in Kazakhstan are the followings: JSC "Almaty Kanty", Karabulak (independent company JSC "Almaty sugar"), Taldykorgan (independent company JSC "Koksu - Sheker"), JSC “ASIA SUGAR”, LLP "Alakol Sheker", LLP "Alakolsky Sugar Plant”, LLP "Shuchinsk Sugar Plant", LLP "Merke sugar plant" and others work a short distance from sowing (sugar beet). Along with the major product they also obtained various types minor products in these enterprises:

- Various acids, yeast alcohol and syrup used in the food industry;

- Molasses, fodder yeast, pulp, used in livestock for fattening animals and birds;

- Defecate and lime used as a fertilizer to produce high yields of sugar beet and cereals.

By fermenting beet or cane waste produce technical ethyl alcohol.

Currently, rarely used wastes includes: filter cake (defecate) in sugar industry, yeast and alcohol bard, as well as carbon dioxide gas of fermentation and a secondary gas of fermentation in alcohol and brewing industries.

Many countries effectively deal with recycling of glass products. The process of recycling glass containers in 17 countries of Western Europe is controlled and coordinated by the European Container Glass Federation. Colored glass is processed completely in all countries. Special organization is established for collection of glass containers.

Rational use of secondary energy resources has a great national economy importance and it defines energy potential of products, waste, minor and intermediate products which are not used in the production. Secondary energy sources are divided into 3 groups:

1) The fuel $\left(\mathrm{H}_{2}, \mathrm{CH}_{4}, \mathrm{CO}\right.$, kiln gases, oil, resin, cellulose);

2) Heat (flue gases, products, minor products, cooling water, exothermic reactions);

3) The pressure of gases and liquids leaving process vessel.

Secondary energy resources are used in nitric, sulfuric, phosphoric, perchloric, soda and petrochemical industry subsectors. Fuel is used as boiler flue. The heat is used in recycling plants, heat-exchange unit for heating of any substance and by this energy consumption is reduced. Pressure is generated in recovery turbine for the operation of compressors, pumps, blowers, as well as power generation

Disposal of waste energy not only saves fuel and energy, but also helps to protect the environment by reducing the heat emission to the atmosphere. 
All boiler of Cherepovets Steel Mill CHP plant (Severstal) operate on the secondary resources [39].

Poultry farming wastes such as feathers are used as a cheap raw material for the production of high quality feed for livestock, flour with protein content up to $85 \%$. Such production is established in Germany. About 1.2 ton of flour is produced from 3 tons waste.

Manure and manure runoff, poultry droppings formed in livestock enterprises are disposed by anaerobic fermentation in special pressurized reactors (digesters). As a result of activity of methanogenic bacteria in an anoxic environment, the fermentation process takes place in reactor at a temperature from 39 to $55^{\circ} \mathrm{C}$ to produce biogas, and remaining solid residue is also a valuable fertilizer. Along with solid residue after fermentation, there is also forms liquid fraction which is easy digestible by plant and devoided of disease-producing factor. It is highly concentrated liquid organic fertilizer, containing macro and micronutrients, amino acids and phytohormones which stimulate the growth of plants [40].

Each year globally, there is observed expansion of biogas production on producing biogas on the base of methane fermentation due to its economy and efficiency. For example, productivity of bioreactors is about 420-600 liters of gas $(60 \%$ methane and $40 \%$ carbon dioxide) per $1 \mathrm{~kg}$ of organic substance.

As it is known there are about $40 \%$ of analytical constituents in poultry manure in the result of incomplete digesting. There have been developed methods for assimilating a type of yeast called Candida on the basis of fermentation process and with their participation, there will be produced a product that can be used as a feed additive for feeding animals and birds [41].

One of the main methods of agricultural waste recycling is called bioconversion. This ecologically clean method based on fermentation of carbohydrate branch of various agricultural wastes (sawdust, straw and other plant residues) and it is widely used for the production of ethanol with rendement of $65-70 \%$.

There is also known heat treatment method s of livestock waste not only for the production of biocompost or organic fertilizer, but also used for the synthesis of bacterial preparations which have protective effect from phytopathogene and also to produce feed additives for fur and feather animals and others [42].

The problem of waste is inextricably linked to the rational use of what we have. On the face of it, it seems a trifle to collect blown bulbs for the extraction of tungsten from them. One blown light bulb contains about $10 \mathrm{mg}$ of tungsten, in million bulbs about $10 \mathrm{~kg}$. To produce $10 \mathrm{~kg}$ of this valuable and deficient metal in the production, it is required to process tungsten-containing 
minerals (wolframite, scheelite) at least 1 ton and also spend a considerable amount of energy. The total geological reserves and their form in tungsten trioxide $\left(\mathrm{WO}_{3}\right)$ are about 6,8 mln tons. The largest reserves are in China, Kazakhstan, Russia, Canada, USA, Bolivia, South Korea. In 2001 in the world, it was produced 44,2 thousand tons of tungsten (content of it in ore) including (country-thousand ton) China - 37,0, Russia - 3,5, Austria - 1,6, Portugal 0,75 , South Korea $-0,7$. Around the world explored reserves will hold out at an average for 50 years at such rate of production. This information underlines the feasibility of reducing emission of tungsten compound [1, 43].

In Romania, there was developed and implemented a method for processing leather waste into plastic mixture from which produce material with properties no different than natural leather in the Institute of Footwear Industry. It is obtained $0,9 \mathrm{~kg}$ material from $1 \mathrm{~kg}$ of waste [23].

Particular attention and urgency is needed for recycling of household waste as there is a direct relationship between the amount of waste and epidemics of various diseases. Among the various types of wastes, particular risk for environment and mainly for people comes from medical and biological waste, despite the fact that their share in the total amount of municipal solid waste is negligible (around 2\%). Only in Moscow, about 16 million of $\mathrm{m}^{3} \mathrm{mu}-$ nicipal waste is generated for a year, about 0,5 million tons of it are medical wastes and this problem is still has not been solved [1].

The problem of medical waste is extremely acute in the world. The United States has reported cases HIV transmission of children after they played with disposable syringe and blood transfusion set throw on the scrap-heap. We know about incident when the HIV spread to nurse when she pricked herself by needle used.

Medical waste is considered not only as a factor of direct risk, but also indirect risk of communicable and non-communicable diseases among the population, due to possible contamination of hospital environment and almost all elements of surrounding environment like water, air, soil and food. It should be noted that the system of collection, disposal, recycling and disposal of medical waste in our country as well as in other countries is not perfect yet and with each year quantity of them growing intensively. For example, due to lack of regulatory framework, the issue on disposal of medical products, prohibited for use or with an expired term of validity and also adulterate drugs seized by customs has not been solved yet.

As it is well known, layer of waste with thickness of $10 \mathrm{~cm}$ cover about 60 million $\mathrm{m}^{2}$. In big cities of the world, it is generated up to $80-90 \mathrm{~kg}$ of food 
waste per person a year. 1 ton of food waste in its nutritional value equivalent to an average of $250 \mathrm{~kg}$ of coarse grains and it makes possible to obtain about $45 \mathrm{~kg}$ of pork.

Distribution of components in municipal waste on average as follows: $\%$ by weight - paper (30-40), food scraps (30-40) and metals (2-4), wood (1,5-3), textiles (2-4), glass (3-6), the stones (1-2), leather, rubber (1-2), plastic $(1-1,5)$. The main destination of municipal waste is dump pile so far, a small part is recycled or incinerated in a specially organized plants [44].

The first waste incineration plant with capacity of 150 thousand ton per year was built in Moscow in 1975. Generated heat is used for heating of steam boilers and the metal scrap is caught from slag and sent to iron and steel plants. Slag is used for the production of building materials. Except for elimination of waste, the plant produces heat, metal, slags which are raw materials for other industries [1].

The waste treatment plant began its operation in the town of Gorelovo outside St. Petersburg in 1972 and the main product of which is compost (manure), but $30 \%$ of raw materials consist plastic, rubber, leather, wood, metals are not recycled there [1].

In Tashkent (Uzbekistan), there is a plant has been operating since 1975 with capacity of 110 thousand tons per year. Annually up to 400 tons of ferrous and 5 tons of non-ferrous metal are extracted from household waste and 20 thousand tons of compost is produced in this plant. However, the method of producing compost is not suitable to all kinds of waste. It depends on composition of wastes. If the proportion of food waste in trash is less than $20 \%$, then it is not possible to produce compost. The content of food waste in household waste is seasonal and characterized by its increase from $20-25 \%$ in spring to $40-55 \%$ in autumn. Especially in the cities of southern zone, it is associated with a greater consumption of fruits and vegetables. When concentration of food components is reduced in waste, the process of composting slows down sharply. The problem is composting is biochemical process proceeded by aerobic microbes. These microbes produce a lot of heat and as a result trash heats up to $70^{\circ} \mathrm{C}$. At the same time disease-causing microbes die, material burns out and it produces compost. Under natural conditions this process would last for months, but in plant by aeration it is completed within 2-3 days.

For the processing of household waste, there is a method of magnetic separation. Superconducting magnet allows conducting separation of all paramagnetic substances and almost all inorganic substances are paramagnetic. Also the strong magnetic fields destroy many kinds of bacteria. 
Tokyo scientists develop trash melting furnace. Mixture of plastics, cans and broken glass goes into furnace after presorting process and after sintering process, volume of mixture is reduced almost 40 times. The final sintered mass is quite suitable material for substitution of gravel in construction of roads [1].

Consequently, according to analysis of literature references, in recent years work on developing new technologies of recycling industrial and municipal waste became more intense to produce either products or their transformed forms suitable for use as raw materials, for certain manufacturing process of various sectors of economy.

Experience has shown that use of man-made wastes as raw materials is one of the most efficient methods for their utilization. On the one hand, this kind of approach can reduce environmental impact, on the other hand it ensures efficiently use of scarce and non-renewal natural resources, substituting primary raw material with secondary one. Many developed countries have been almost completely and successfully solving all these problems. This is particularly so with Japan, USA, Germany, France, the Baltic countries and many others.

The serious problem causing for Kazakhstan are solid wastes, as there are no facilities for processing them. Every year, there has been accumulated more than 14 million solid waste at the rate of 1,3 to $2,2 \mathrm{~m}^{3}$ per inhabitant. The complexity of solving the utilization problems with full use of both solid industrial waste and domestic waste is lack of clear scientifically based classification, necessity of use complicated capital-intensive equipment and lack of economic feasibility of each specific solution. So far, cheapest and most appropriate method of waste management is sanitary landfills designed for longterm and safe disposal.

According to Ministry of Environment report, there has been accumulated 23 billion tons of solid waste in the territory of country. Every year amount of accumulated solid waste is increasing by an average of $700 \mathrm{mln}$ tons. To solve problem with garbage, there is planned and has started implementation of pilot projects on solid domestic waste management in the following cities: Almaty, Aktau, Astana, Dzhambul, Karaganda, Chimkent, Petropavlovsk and Ust-Kamenogorsk. It is planned to achieve water recycling level to $70 \%$ by separating substances that can be recycled from domestic and industrial waste by 2020 .

It should be noted that implemented technologies of processing solid waste in the world have number of disadvantages. The main ones are their poor environmental study related to formation of secondary waste containing toxic organic compounds and a high processing cost. It is specifically related 
to waste containing chlorinated derivatives and releasing highly toxic organic compounds (dioxins, etc.). Dioxin formation components of MSW are materials such as cardboard, paper, plastic, PVC products, etc.

Remaining major problem is utilization of wastes containing toxic substances which are luminescent lamps, mercury-containing devices (thermometers, batteries, etc.). Specially designed places for destruction of products out of date.

Oil-producing, transporting and processing industries are the most ecologically dangerous branches of the economy, as the scale of production increase is accompanied by growth of oil pollution and waste. This causes a build-up of environmental threats, reducing the area of economic land, soil loss and deterioration of health. Besides company operates at high pressures and temperatures, with highly toxic, flammable and explosive substances and respectively they are sources of increased technological and environmental risks.

Further you can find existing oil and gas industry environmental problems associated with processing waste and consumption, as well as the way out of this difficult situation.

\subsubsection{The main types of oil and gas industry wastes and their use as a secondary raw material}

The large-scale exploitation of mineral resources and increase of oil refining accompanied by high risk of pollution starting from exploration phase and production of oil and ending the use of petroleum products. Pollution occurs during well drilling process and preparation them for operation. Drilling wells is accompanied by dispersive rock breaking, formation of drilled cuttings, removing them by flush water. The main types of technological wastes generated during drilling of well are drilling waste water which is waste drilling mud, drilled cuttings and also soil contaminated with oil, scrap metal, solid waste, used drums containers and others.

Besides, there is is formed oil sludge, paraffin plug and waste oil in exploitation well and producing wells of oil, gas and condensate. Oil sludge, crystal hydrate plug, waste oil and solid filter media is formed in oil and gas pipeline transport facilities. In storage and reforming facilities, the main wastes are oil sludge, acid sludge, waste catalyst, adsorbents, purging of processing equipment and vessels, used dehumidifiers and molecular gates.

The formation of significant amount of oil-contaminated waste reduce economic efficiency of oil and gas industry, due to the necessity of alienation territory of enterprises under their storage, increasing environmental charges for storage of waste and pollution emissions. 
Statistics on the quantity of waste formed during drilling and their characteristics are presented in Table 1.2 per their characterization.

Table 1.2

Average volume and types of the main wastes formed from one well

\begin{tabular}{|l|c|l|}
\hline \multicolumn{1}{|c|}{ Name of waste } & Volume & \multicolumn{1}{c|}{ A method of utilization } \\
\hline Drilled cuttings & $46 \mathrm{~m}^{3}$ & Storing in sludge reservoir \\
\hline Waste drilling mud & $5 \mathrm{~m}^{3}$ & Storing in sludge reservoir, reuse \\
\hline Drilling waste water & $10 \mathrm{~m}^{3}$ & Reuse \\
\hline Soil contaminated with oil & 0,7 ton & $\begin{array}{l}\text { Storing in sludge reservoir after completion } \\
\text { of work }\end{array}$ \\
\hline Packing waste SMW & 5,3 ton & Burning in an incinerator \\
\hline Used drums, canisters & $20 \mathrm{ps}$ & Reuse or sent to recycling \\
\hline
\end{tabular}

Drilling waste water is multicomponent suspensions which contain up to $80 \%$ of fine impurities. They are for high aggregate stability. Contaminants are divided into dissolvable organic impurities and petroleum products in them. This water is stored in a tank and settled and reused.

Waste drilling mud is formed during construction of well. Its pollution potential is estimated by content of oil and organic impurities in them. The estimation is made by COD measures (chemical oxygen demand), $\mathrm{pH}$ and mineralization.

Drilled cuttings are drilled solid, separated from mud fluid by purification equipment. It is formed during $\mathrm{POOH}$ when flushing water flows out of lifted up drill pipe stand above rotary table and also while washing of circulation system, the working platform at rotor, drill pipe, pipeline. There are formed up to $2 \mathrm{~m}^{2}$ rock fragments for 1 meter drilled length during drilling process. Its mineral composition is not toxic but by dispersing into drilling mud environment, its particles adsorbs toxic substances (hydrocarbon, various additives up to $15 \%$ ) on its surface and has harmful effects on vegetation cover and other biota. Many scientists' researches have shown that except hydrocarbon, toxic drilled cutting contains surface-active reagent, calcium hydroxide, sodium carbonate, acid, oil up to 7,5 and $37 \%$ of weights. Liquid phase is separated from drilled cutting and after appropriate treatment, it is used again. Solid phase is currently used in many fields for building 
Infield roads and it is preliminary mixed with soil. These wastes are IV class of hazard.

Oil contaminated soil (soil contaminated with oil products) is formed during drilling equipment operation, motor vehicle operation, during loading and unloading combustive and lubricating materials in vessels, etc. Hazard class contaminated soil is III.

The greatest migration ability in drilling mud has salt water and water-oil emulsion. On the territory of field, soil, surface water and ground water polluted with oil products and oilfield waste water. As a result there is humus content, acid-alkali balance, fermentation activity in soil.

Oil and oil products spill reduce biological productivity of soil and biomass of vegetation cover. If there is $121 / \mathrm{m}^{3}$ oil spill, in 3 years phytomass of above-ground parts of plats will be reduced to $74 \%$, if there is $251 / \mathrm{m}^{3}$ oil spill, then to $90 \%$ in one year. Self-generation period of vegetation cover for northern condition is 10 to 15 years and for south part condition much less [45].

Oil sludge deserves special attention among wastes of oil production which contains a sufficiently wide range of mineral particles (50-75\%), crude oil $(20-40 \%)$ and water (5-10\%). Oil sludge is also produced in large volume during crude refining. The composition of these oil sludes mainly represented from organic portions (oil products, additives and surface-active substance), mineral parts (calcium carbonate, carbonate of magnesia, calcium hydrate, aluminum, iron at the following volumetric ratio of components $(\%)$, respectively $2,4: 1,6: 2,0)$.

In Table 1.3 presented data describing the main field of oil sludge and oil soil use as secondary raw material [45].

The greatest danger to environment in field development is hydrocarbon emission and waste water discharge. Each year, 7 billion cub. $\mathrm{m}$ of gas is burned in flare system which forms not more than $20 \%$ from all recoverable volume. Taking into account oil gas during production activity about 3,5\%. About $3,5 \%$ of crude oil is lost during productivity activity taking into account oil gas.

Nowadays no more than $70 \%$ of oil-associated gas is utilized, and the rest part is burned in the flares. Basically oil-associated gas is performed by methane, nitrogen, oxygen and carbon dioxide gas. The environment is polluted by heat while gas is burned in flares, which cause greenhouse effect in troposphere ground-level. 
Ways of using oily sludge as a secondary raw material

\begin{tabular}{|c|c|c|}
\hline \multicolumn{3}{|c|}{ Industrial fields using oily sludges } \\
\hline Industrial waste & $\begin{array}{l}\text { Types of produced pro- } \\
\text { ducts and concentration } \\
\text { of injected oily sludge, } \\
\text { weight percentage } \%\end{array}$ & Aim of using oily sludge \\
\hline 1 & 2 & 3 \\
\hline \multicolumn{3}{|c|}{ Road building } \\
\hline \multirow[t]{3}{*}{ Oil industry sludge } & Asphalt concrete, 1-2 & \multirow{4}{*}{$\begin{array}{l}\text { Increase of mechanical strength, } \\
\text { water resistance and freeze } \\
\text { resistance. } \\
\text { Decrease of expansion and } \\
\text { consolidation }\end{array}$} \\
\hline & Gas concrete, 1 & \\
\hline & Sludge concrete, $86-87$ & \\
\hline $\begin{array}{l}\text { Industrial oil con- } \\
\text { taminated soil }\end{array}$ & $\begin{array}{l}\text { Oil contaminated soil, } \\
95-96\end{array}$ & \\
\hline \multicolumn{3}{|c|}{ Industrial fields using oily sludges } \\
\hline Oil sludge & $\begin{array}{l}\text { Waterproofing material for } \\
\text { built-up bituminous roofing }\end{array}$ & $\begin{array}{l}\text { Reducing temperature and time } \\
\text { for agitation of mix }\end{array}$ \\
\hline $\begin{array}{l}\text { Oily sludge obtained } \\
\text { from oil salvage }\end{array}$ & $\begin{array}{l}\text { Roofing and hydraulic } \\
\text { insulatoing mastic, } 30-50\end{array}$ & Reduction of bitum usage \\
\hline $\begin{array}{l}\text { Oily sludge formed } \\
\text { in oil refining } \\
\text { process }\end{array}$ & $\begin{array}{l}\text { Waterproofing compound, } \\
100\end{array}$ & Utilization \\
\hline $\begin{array}{l}\text { Oily sludge obtained } \\
\text { in various produc- } \\
\text { tion fields }\end{array}$ & $\begin{array}{l}\text { Lightweight aggregate, } \\
20-50\end{array}$ & Reduction of pour density \\
\hline Oily sludge & Expanded clay, 1-10 & $\begin{array}{l}\text { Reduction of fuel volume weight } \\
\text { and usage }\end{array}$ \\
\hline Oily sludge & Bricks, $10-12$ & $\begin{array}{l}\text { Increase of mechanical strength, } \\
\text { freeze resistance, porosity }\end{array}$ \\
\hline \multicolumn{3}{|c|}{ Industrial fields using oily sludges } \\
\hline Industrial waste & $\begin{array}{l}\text { Types of produced products } \\
\text { and concentration of } \\
\text { injected oily sludge, weight } \\
\text { percentage \% }\end{array}$ & Aim of using oily sludge \\
\hline $\begin{array}{l}\text { Oily sludge formed } \\
\text { in oil refining } \\
\text { process }\end{array}$ & Rubber mix, 5-10 & $\begin{array}{l}\text { Increase of plasticity, strength } \\
\text { and unit extension }\end{array}$ \\
\hline Acid sludge & Bitum, 100 & $\begin{array}{l}\text { Expansion of the raw material } \\
\text { base }\end{array}$ \\
\hline
\end{tabular}


Continuation of table table 1.3

\begin{tabular}{|c|c|c|}
\hline \multicolumn{3}{|c|}{ Industrial fields using oily sludges } \\
\hline Industrial waste & $\begin{array}{l}\text { Types of produced pro- } \\
\text { ducts and concentration } \\
\text { of injected oily sludge, } \\
\text { weight percentage } \%\end{array}$ & Aim of using oily sludge \\
\hline 1 & 2 & 3 \\
\hline \multicolumn{3}{|c|}{ Oil and gas industry } \\
\hline $\begin{array}{l}\text { Oily sludge - } \\
\text { cake-oil prepara- } \\
\text { tion process waste }\end{array}$ & $\begin{array}{l}\text { Insulating compound, drill- } \\
\text { ing mud, 25-50 }\end{array}$ & Increase of hydraulic insulation \\
\hline \multicolumn{3}{|c|}{ Fuel industry } \\
\hline $\begin{array}{l}\text { Top of oily sludge } \\
\text { pit }\end{array}$ & Boiler fuel, 9-14 & $\begin{array}{l}\text { Decrease of commercial crude } \\
\text { oil usage }\end{array}$ \\
\hline $\begin{array}{l}\text { Mix of slop oil and } \\
\text { oil sludge after } 2^{\text {nd }} \\
\text { and } 3^{\text {rd }} \text { levels of } \\
\text { dehumidification }\end{array}$ & Marine fuel, 25-50 & $\begin{array}{l}\text { Decrease of commercial fuel oil } \\
\text { usage }\end{array}$ \\
\hline $\begin{array}{l}\text { Liquid oil wastes of } \\
\text { Oil Refinery Plant } \\
(5-20) \text { and petro- } \\
\text { leum oils production } \\
\text { wastes (9-67) }\end{array}$ & Patch fuel & $\begin{array}{l}\text { Increase of calorific heat value, } \\
\text { mechanical strength and heat } \\
\text { resistance }\end{array}$ \\
\hline
\end{tabular}

In the course of Caspian oilfields development, main part of polluting substances flows into water on the territory of industrial facilities from following field equipment units:

- Well mouth and circumwell areas, where often oil spills take place due to loss of wellhead sealing and when repair works are performed;

- Gauging tanks and paths of group and individual pre-fabricated units, where leakages and oil spills can happen if gauging tanks are overfilled, in the process of cleaning them from mud and paraffine;

- Pre-fabricated areal and field tank farms, where oil spills often take place while discharging of sewage from tanks and oil overflow from the top of the tanks.

The problem of oil pollution has become very critical in North Caspian in recent times, as due to imperfection of oil extracting complex system and equipment in its offshore area and increased volume of crude oil and oil products shipment by tankers a systematic accumulation of enormous mass of oil slicks is observed. A considerable amount of oil comes into the sea 
in the result of ships wrecking, especially tank ships. Main oilfield and oil refining objects, where sewage is formed are complex oil treatment units and various crude oil distillation and oil deep conversion units, which perform processes of desalinization, demulsification, stabilization, dehumidification, distillation, coking and others, and oil tank farms as well [46-47].

Due to the fact that Kazakhstan's oil is very rich with sulfur compounds, Caspian ecosystem is polluted by hydrogen disulfide and mercaptans. The biggest hazard in Caspian Sea shelve area is posed by heavily polluted sewage of desulfurization and gas dewatering, containing amines, hydrosulfuric acid and other substances.

On the oil-producing facilities, Tengiz filed in particular, drilling wastes are neutralized with the help of biological methods. Biological process is associated with ability of microorganisms to decompound wastes into non-hazardous products, such as carbon dioxide, water and biomass by biochemical reaction. The number of microorganisms and oxygen for cell metabolism, balanced number of nutritive substances and microelements, as well as humidity, temperature, $\mathrm{pH}$ and optimum salt content belong to the most important factors, providing biochemical decomposition of hydrocarbons. Except for above mentioned factors the behavior of biochemical decomposition process considerably depends on content of decomposed compounds.

The technology of bio treatment is broadly used in geological exploration and oil and gas industry and it includes composting and ground treatment. The main objective of these methods is to decrease the overall concentration of hydrocarbons in sludge to such level, when it stops being hazardous for the environment.

Composting method represents a process of high-temperature aerobic decomposition, in the process of which wastes are mixed with loosening materials, formed into piles and rolls, and then aerated with the help of special devices or turned over. In case of ground treatment a thin layer of drilling waste is spread on specially allocated area and turned into the soil.

Ecological hazard of noxious substances evaporating into the air in the result of oil and gas extracting and processing on industrial objects is characterized by the following data, performed in Table 1.4.

Environment is considerably polluted while oil is transported, especially a definite ecological hazard is performed by sea oil transportation. This can happen due to the pipelines rupture and accidental spills. Metal corrosion, manufacturing defect, construction and assembling operations defects, mechanical damage and etc. can also be a reason. For example, approximately 500-700 cases of accidents can take place on Kazakhstani pipelines during the period of one year, the oil loss in such case amounts to 1,5 mln tons. 
Table 1.4

Characteristics of noxious substances evaporating into the atmosphere in the result of oil and gas extracting and processing

\begin{tabular}{|c|c|c|c|}
\hline \multirow{3}{*}{$\begin{array}{l}\text { Substance } \\
\text { (gas, steam) }\end{array}$} & \multicolumn{3}{|c|}{ Sanitary concentrations, mg/cu m } \\
\hline & \multirow{2}{*}{ Fatal } & \multicolumn{2}{|c|}{ MPC in atmosphere } \\
\hline & & working area (class of hazard) & residential area \\
\hline Methane & 235000 & $300(4)$ & 200 \\
\hline Ethane & 125000 & $300(4)$ & 200 \\
\hline Propane & 86000 & $300(4)$ & 200 \\
\hline Butane & 62000 & $100(4)$ & 200 \\
\hline Gas condensate & 50000 & $300(4)$ & 5 \\
\hline $\mathrm{NO}_{2}$ & 1200 & $5(2)$ & 0,005 \\
\hline $\mathrm{CO}$ & 12500 & $20(4)$ & 3 \\
\hline $\mathrm{CO}_{2}$ & 410000 & $78500(4)$ & 9800 \\
\hline $\mathrm{SO}_{2}$ & 1460 & $10(3)$ & 0,05 \\
\hline $\mathrm{CH}_{3} \mathrm{OH}$ & 6000 & $5(3)$ & 1 \\
\hline $\mathrm{H}_{2} \mathrm{~S}$ & 4620 & $10(2)$ & 0,008 \\
\hline $\mathrm{NH}_{3}$ & 700 & $20(4)$ & 0,2 \\
\hline Black & 5000 & $4(4)$ & 0,15 \\
\hline $\mathrm{SO}_{3}$ & 20 & $1(2)$ & - \\
\hline
\end{tabular}

Tengiz oil is in high demand on the worldwide market due to its high quality. It is easily processed into petrol, diesel fuel and other products. TCO considerably contributes to development of overall Kazakhstan's economy, extracting and exporting more than $33 \%$ of oil volume nation-wide [47]. Picture 1.1 performs main types of products, produced by TCO enterprise.

In accordance with process flow scheme presented in Picture 1.3 in the process of purification of crude oil and gas from hydrogen sulfide a byproduct is produced - free sulfur, which is also a valuable raw product, that is in demand on worldwide market. Tengiz sulfur with its highest degree of purity in the world $-99,99 \%$ is quite a rival product. In this regard, having studied the requirements of potential consumers, TCO invested considerable funds into construction of granulated and flaked sulfur forming units $-\$ 100 \mathrm{mln}$. (Picture 1.2).

Granulated sulfur is oriented to Mediterranean countries' market, flaked sulfur - to market of Chinese Peoples Republic. 


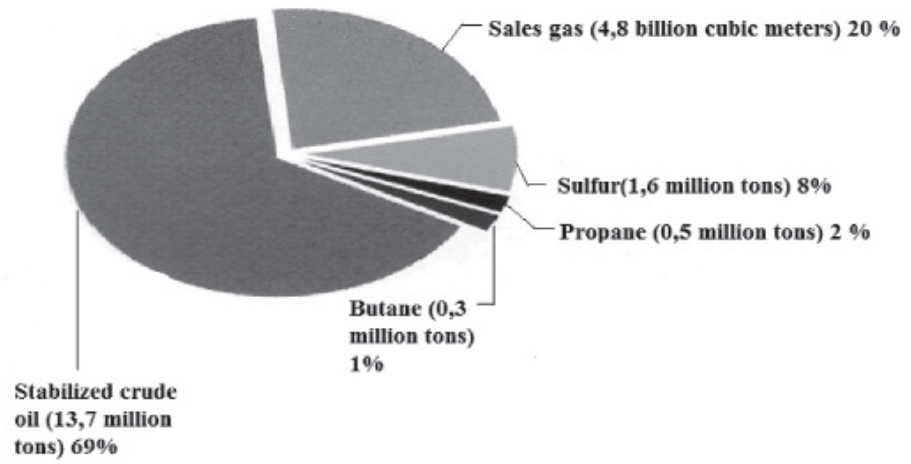

Picture 1.1. Types of products, produced from crude oil recovered by TCO

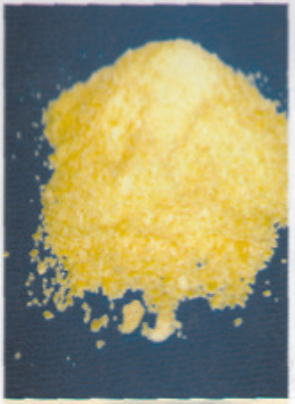

Flake sulfur

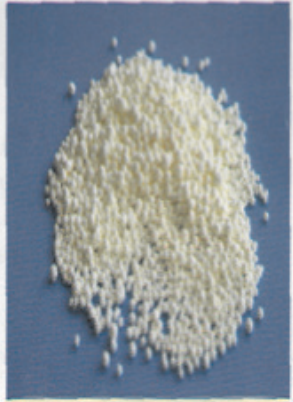

Granulated sulfur

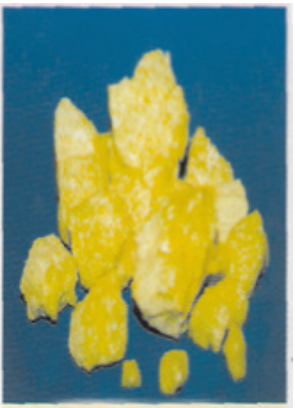

Crushed sulfur

Picture 1.2. Forms of marketable sulfur

In recent time TCO has been selling the entire assortment of sulfur: liquid, transportable in railway tanks, granulated and flaked, transportable in plastic bags, solid (crushed), transportation of which is conducted in special railway cars according to a technology, excluding formation of dangerously explosive sulfur dust.

Today's TCO production capacity of sulfur granulation (more than 800 thousand tons) already allows the enterprise to process its entire annual production volume into marketable products. Except for Chinese Peoples Republic with its giant requirements, defining steadily increasing perspective of sulfur supply, amongst main consumers of this type of product are Tunisia, Israel, Morocco and other Mediterranean countries, as well as Russian Federation and partly Kazakhstan, which mostly buy liquid and crushed sulfur. 


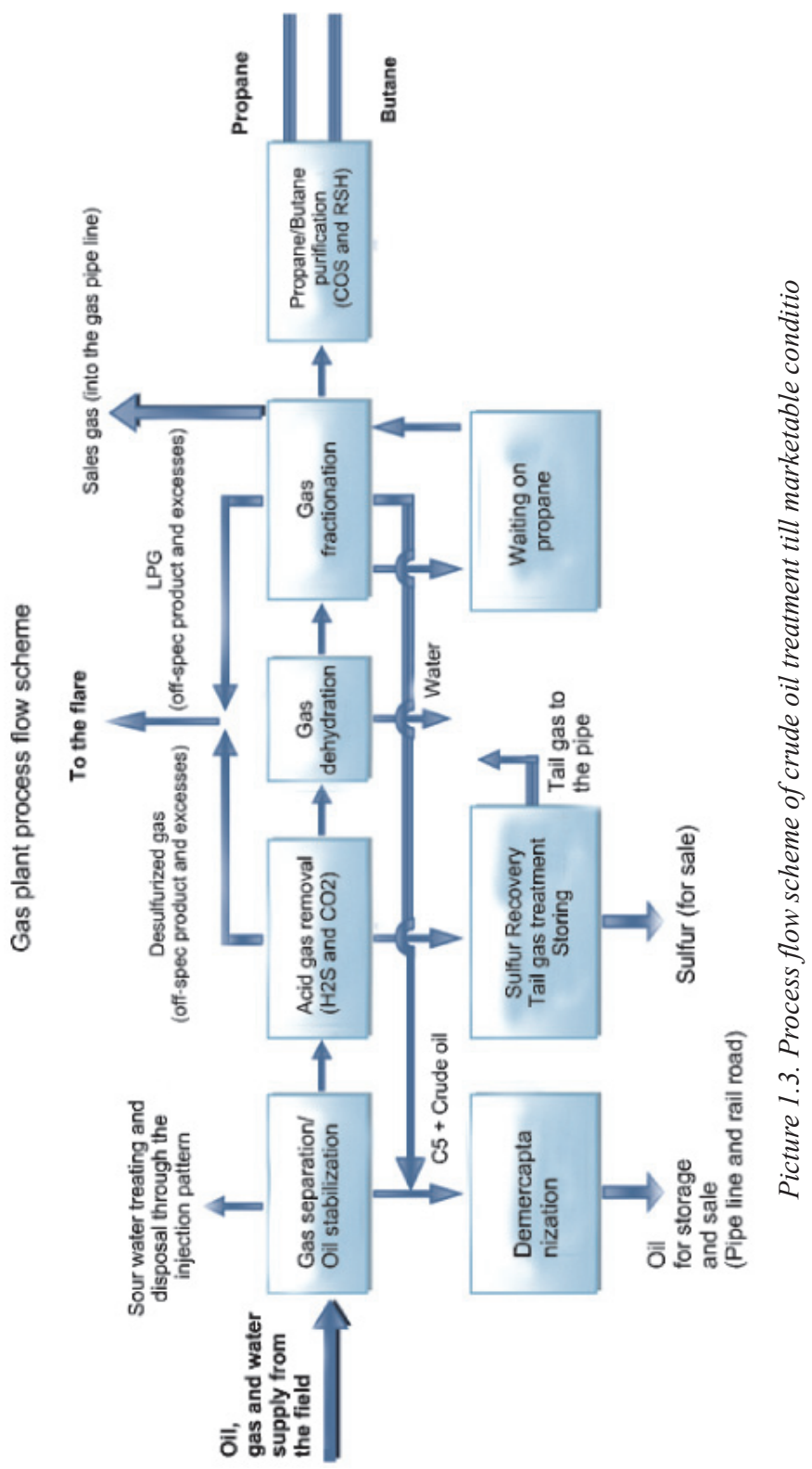


Removal of sulfur dioxide from gas is no less important objective. The general amount of sulfur, which is vented in our country in the form of sulfur dioxide gas only, composes about $16 \mathrm{mln}$ tons per year, i.e. up to $40 \mathrm{mln}$ tons of sulfuric acid could be produced out of this amount of sulfur. Except for listed above substances several billions cubic meters of carbon dioxide is vented every year from plant pipes and power generation. With reasonable approach this gas can be used for production of effective coal-containing fertilizers.

As it follows from the analysis of literary and production data in future, there will be a sharp increase of necessity of free sulfur in different sectors of national economy in many countries of the world. For example, more than 12 million tons of sulfur is used yearly to produce more than 30 thousand names of sulfur containing products in the USA [46-48].

\section{CHAPTER CONCLUSIONS}

1. The ways of reducing the impact of metallurgic, oil and gas, heat and power, agricultural, utilities and other complexes production on the state of the environment are considered. Sufficiently detailed description of main types of process waste, formed on production and development wells and other oil and gas facilities is given.

2. The possibility to reduce the volume of accumulated waste and to reduce the generation of waste through the introduction of advanced technologies of their processing and disposal is shown. Due to environmental and economic reasons the attention is focused on the urgency of the problem of process waste disposal and usage. At present the necessity to develop chemical production of mineral fertilizers and other products based on using oil and other productions waste as a secondary raw material is becoming increasingly obvious. 


\section{PROCESS METHODS OF UTILIZATION OF THE OIL AND GAS INDUSTRY SULFUR CONTAINING WASTES WITH PRODUCTION OF BACTERICIDES AND FERTILIZES}

\subsection{Methods for production of ammonium salts and their properties}

In Kazakhstan, several million tons of sulfur (about $70 \mathrm{~kg}$ of sulfur per 1 ton of oil) are being accumulated per year, as a result of oil treatment. This sulfur not only occupies a large area of land for its storage, but also due to the variety of chemical reactions with other components contained in the environment and formation of secondary toxins, causes significant damage to all biota, including humans. For example, the exposure to the high concentrations of sulfur dioxide leads to the acute necrosis and leaf chlorosis of the plants, early leaf fall, decrease of the mass of dry matter, total area and quantity of leaves, reduction of the wood growth, change of the root/leaf ratio. As a result of the sulfur dioxide contamination the complete elimination of the vegetation was found in vicinity of the industrial sites. The important consequences of the sulfur dioxide impact can be the reduction of the resistance of the plants to the drought season, frost, soil salinization, plant pests and different diseases.

Contaminated by the sulfur compounds atmosphere contributes to nosogeny of various diseases, such as chronic bronchitis and other respiratory diseases, asthma, emphysema, etc. In this regard, at the present time the utilization of sulfur and its compounds emitted as wastes during the treatment of the sulfur crude oil and high-sulfur crude oil is the actual problem.

As it was mentioned before in Kazakhstan the Tengiz crude oil is the high-sulfur crude oil. Sulfur containing components are presented mainly by the Mercaptans (to 0,09 wt. \%), sulfides, disulfides (up to 0,2 wt.\%), elemental sulfur, hydrogen sulfide (up to $1 \mathrm{wt} \%$ ). Besides, these components are unevenly distributed by fractions. The greatest amount of sulfur compounds, except mercaptans is contained in the heavy fractions $(350-500)^{\circ} \mathrm{C}$. For example, if in the light fractions $(62-200)^{\circ} \mathrm{C}$ their content does not exceed 0,23 wt. $\%$, in heavy fractions it reaches $1,29 \%$. The main content of the Mercaptans, conversely, is in the light fraction (up to $0,15 \%$ ), the middle fraction $(120-240)^{\circ} \mathrm{C}$ to $0,07 \mathrm{wt} . \%$ and in the heavy fraction it is even lower. Desulfurization and demercaptanization of hydrocarbon crude shall be carried 
out using a set of different chemical methods: adsorption, extraction, catalytic hydrogenation, liquid-phase oxidation and others. Hydro treatment method is widely used to remove the sulfur compounds from the crude oil. It is based on the use of Hydrogen for the hydrogenolysis of the following reactions; Hydrogen Sulfide is one of their main products:

a) mercaptan

$$
\mathrm{RSH}+\mathrm{H}_{2} \rightarrow \mathrm{RH}+\mathrm{H}_{2} \mathrm{~S}
$$

b) acyclic, mono-, bicyclic sulfides, thiophenes

$$
\begin{gathered}
{ }_{\mathrm{S}}+2 \mathrm{H}_{2} \rightarrow \mathrm{C}_{4} \mathrm{H}_{10}+\mathrm{H}_{2} \mathrm{~S} ; \\
{ }_{\mathrm{S}}+3 \mathrm{H}_{2} \rightarrow \mathrm{C}_{7} \mathrm{H}_{12}+\mathrm{H}_{2} \mathrm{~S} ; \\
+2 \mathrm{H}_{2} \rightarrow \mathrm{C}_{4} \mathrm{H}_{9} \mathrm{SH}+\mathrm{H}_{2} \rightarrow \mathrm{C}_{4} \mathrm{H}_{10}+\mathrm{H}_{2} \mathrm{~S} .
\end{gathered}
$$

The resulting during desulfurization process Hydrogen Sulfide is recovered and further processed by Claus process on the titan-catalysts into elemental sulfur with a yield of $99,9 \%$ [49]. In addition, besides of the elemental sulfur formation the partial formation of its oxide is possible according to the reactions:

$$
\begin{gathered}
2 \mathrm{H}_{2} \mathrm{~S}+\mathrm{O}_{2} \rightarrow \mathrm{S}_{2}+2 \mathrm{H}_{2} \mathrm{O}+(0,4-0,413) \mathrm{mJ} \\
\mathrm{S}_{2}+2 \mathrm{O}_{2} \rightarrow 2 \mathrm{SO}_{2} .
\end{gathered}
$$

More than $70 \% \mathrm{SO}_{2}$ in the system shall enter into the following reaction:

$$
2 \mathrm{H}_{2} \mathrm{~S}+\mathrm{SO}_{2} \leftrightarrow 2 \mathrm{H}_{2} \mathrm{O}+3 / n \mathrm{~S}_{n}+(0,087-0,145) \mathrm{mJ} .
$$

Formed as wastes elemental sulfur, is a valuable product for carrying out different chemical processes, to produce various valuable market products with the help of the established technologies.

We have considered the opportunity to produce Ammonium Salts (sulfate bisulfate, persulfate), sodium thiosulfate, potassium sulfate) from the sulfur containing wastes of the Oil Industry.

The Process Flow Diagram for production of the market products on the base of the utilization of the sulfur containing wastes shall be presented at picture 2.1. The salts presented in the Process Diagram had been produced under Laboratory conditions. 


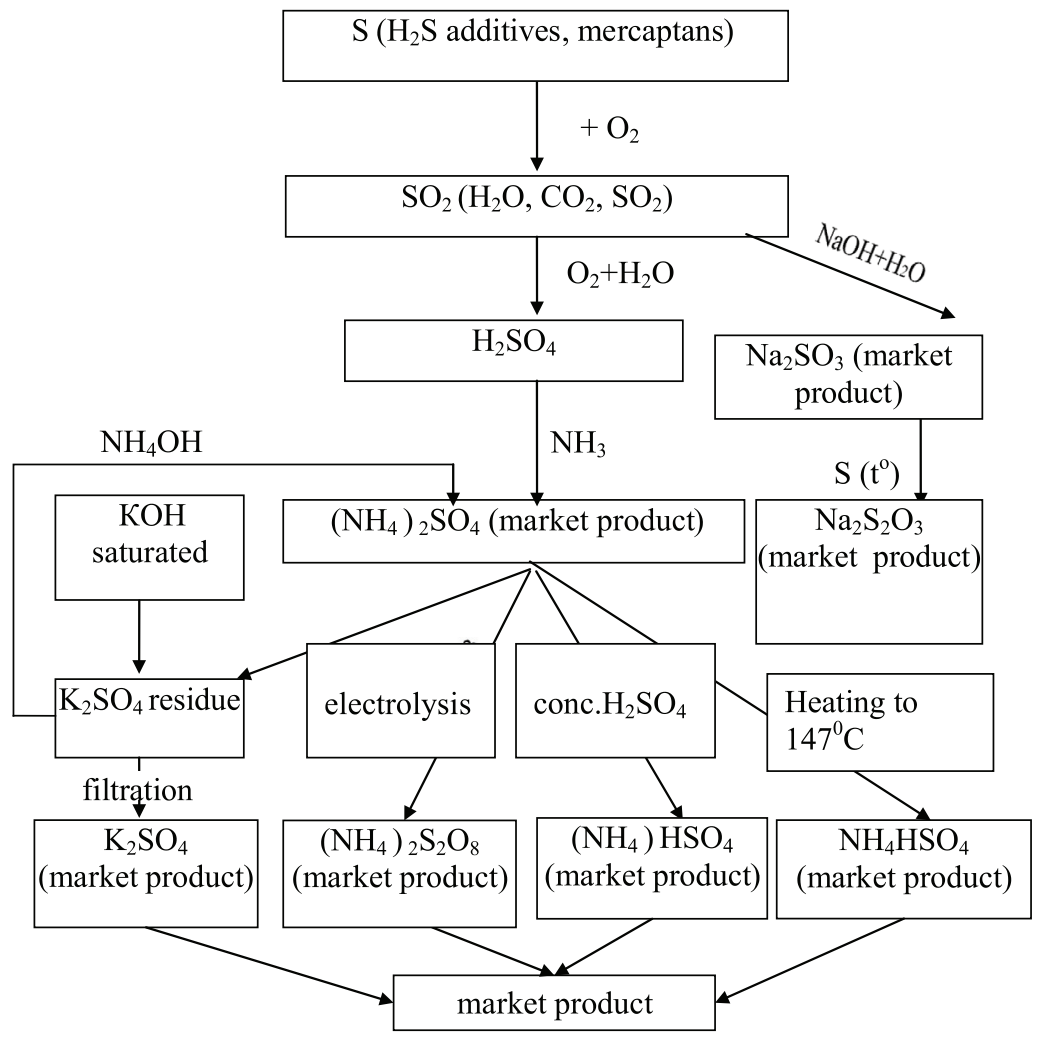

Picture 2.1. Process Flow Diagram of Sulfur Containing Wastes Processing with Output of Market Products

Gaseous sulfur oxide (IV) can be oxidized to an oxide (VI) by the established catalytic process in contactor at $t=450^{\circ} \mathrm{C}$, and further produce the sulfuric acid of any concentration from it. From the sulfuric acid the synthesis of salts of ammonium sulfate and bisulfate in the form of the market products shall be carried out by the following transformations:

$$
\mathrm{S}_{2}\left(\mathrm{H}_{2} \mathrm{~S}\right) \stackrel{\mathrm{O}_{2}}{\rightarrow} \mathrm{SO}_{2} \stackrel{\mathrm{O}_{2}}{\rightarrow} \underset{\mathrm{H}_{2} \mathrm{O}}{\rightarrow} \mathrm{H}_{2} \mathrm{SO}_{4} \stackrel{\mathrm{NH}_{3}}{\rightarrow}\left(\mathrm{NH}_{4}\right)_{2} \mathrm{SO}_{4} \stackrel{\mathrm{H}_{2} \mathrm{SO}_{4}}{\rightarrow} \mathrm{NH}_{4} \mathrm{HSO}_{4}
$$

It is possible to get ammonium sulfate $\left(\mathrm{NH}_{4}\right)_{2} \mathrm{SO}_{4}$ using $\mathrm{NH}_{4} \mathrm{OH}(25 \%)$ and $\mathrm{H}_{2} \mathrm{SO}_{4}(20 \%)$ solutions. Reaction shall be carried out under good chilling 
conditions by adding insignificant excessive quantity of ammonium hydroxide to obtain an alkaline medium. Then, the resulting liquid shall be heated until boiling, filtered, and the colorless filtrate shall be evaporated till separation of the ammonium sulfate in a crystal form. The ammonium sulfate is easy soluble in water (e.g., at $20^{\circ} \mathrm{C}$ makes $43,0 \%$ ) and is alcohol-insoluble compound, melting point is $326-329^{\circ} \mathrm{C}$, a decomposition temperature is $355^{\circ} \mathrm{C}$. Ammonium sulfate is used in the chemical industry as feed for the synthesis of other compounds.

It is possible to use the ammonium sulfate not only for obtaining of the bisulfate but also the other salts. E.g. Ammonium sulfate is the raw material for the synthesis of ammonium persulfate in sulfuric acid medium by the electrochemical method (without the diaphragm and with diaphragm) using platinum or lead cathodes:

$$
\left(\mathrm{NH}_{4}\right)_{2} \mathrm{SO}_{4} \stackrel{\text { Electrolysis }}{\longrightarrow}\left(\mathrm{NH}_{4}\right)_{2} \mathrm{~S}_{2} \mathrm{O}_{8} \text {. }
$$

The solubility in water of the ammonium persulfate at the ambient temperature makes $\approx 36,7 \%$.

While heating the solid ammonium persulfate the oxygen is emitted and ammonium metabisulfite $\left(\mathrm{NH}_{4}\right) 2 \mathrm{~S}_{2} \mathrm{O}_{7}$ is formed (2.11). And while heating water solutions of ammonium persulfate also the oxygen is easily released and acidic ammonium sulfate is formed (2.12)

$$
\begin{gathered}
\left(\mathrm{NH}_{4}\right)_{2} \mathrm{~S}_{2} \mathrm{O}_{8} \rightarrow\left(\mathrm{NH}_{4}\right)_{2} \mathrm{~S}_{2} \mathrm{O}_{7}+\mathrm{O}_{2} ; \\
\left(\mathrm{NH}_{4}\right)_{2} \mathrm{~S}_{2} \mathrm{O}_{8} \rightarrow \mathrm{NH}_{4} \mathrm{HSO}_{4}+\mathrm{O}_{2} .
\end{gathered}
$$

Ammonium persulfate in dry state lasts without decomposition for the unlimited time; wet salt at ambient temperature gradually decomposes releasing ozonated oxygen.

Picture 2.1 shows the possibility of the bisulfate production in two ways: by thermal decomposition of the ammonium sulfate (2.13) or mixing of the ammonium sulfate with concentrated sulfuric acid (2.14) by the following reactions:

$$
\begin{gathered}
\left(\mathrm{NH}_{4}\right)_{2} \mathrm{SO}_{4} \rightarrow \mathrm{NH}_{4} \mathrm{HSO}_{4}+\mathrm{NH}_{3} ; \\
\left(\mathrm{NH}_{4}\right)_{2} \mathrm{SO}_{4}+\mathrm{H}_{2} \mathrm{SO}_{4} \rightarrow 2 \mathrm{NH}_{4} \mathrm{HSO}_{4} .
\end{gathered}
$$

Production of the bisulfate by the first way (2.13) shall be carried out at the temperature of not lower than $491 \mathrm{~K}$, heating is carried out to $\mathrm{pH} 5-7$, ie to the disappearance of the reaction to ammonia, the control shall be carried 
out by using water dampened multi purpose $\mathrm{pH}$ indicator paper. The emitted vapors containing ammonia shall be water sprayed to obtain a solution of ammonia, which is recycled to the stripping of sulfuric acid in the preparation of ammonium sulfate.

By our point of view the second way technology is more advantageous (2.14). To produce $1 \mathrm{~kg} \mathrm{NH} \mathrm{NSO}_{4}$ they constitute mix at $0,57 \mathrm{~kg}\left(\mathrm{NH}_{4}\right)$ $2 \mathrm{SO}_{4} 232 \mathrm{ml}$ of $98 \% \mathrm{H}_{2} \mathrm{SO}_{4}$ solution, then thoroughly mix it, heat to $420 \mathrm{~K}$ and bring it to the melted state and then pour into a stainless steel mold and after that chilled salt is packed in a plastic bag.

Sodium thiosulfate is widely used in various industries, it can also be produced by using sulfur as raw material for the following methods:

- by boiling the solution of sodium sulfate with the sulfur powder:

$$
\mathrm{S}+\mathrm{Na}_{2} \mathrm{SO}_{3} \rightarrow \mathrm{Na}_{2} \mathrm{~S}_{2} \mathrm{O}_{3}
$$

- by reaction of $\mathrm{H}_{2} \mathrm{~S}$ and $\mathrm{SO}_{2}$ with $\mathrm{NaOH}$ (byproduct in production of $\mathrm{NaHSO}_{3}$, sulfur dyes, in the process of $\mathrm{S}$ removal from industrial gases):

$$
4 \mathrm{SO}_{2}+2 \mathrm{H}_{2} \mathrm{~S}+6 \mathrm{NaOH} \rightarrow 3 \mathrm{Na}_{2} \mathrm{~S}_{2} \mathrm{O}_{3}+5 \mathrm{H}_{2} \mathrm{O}
$$

- by boiling of sulfur excess with sodium hydroxide:

$$
3 \mathrm{~S}+6 \mathrm{NaOH} \rightarrow 2 \mathrm{Na}_{2} \mathrm{~S}+\mathrm{Na}_{2} \mathrm{SO}_{3}+3 \mathrm{H}_{2} \mathrm{O} .
$$

Then according to the above reaction (2.15) the sodium sulfite adds sulfur to form sodium thiosulfate. Simultaneously during this reaction, sodium polysulfides are formed (they give the yellow color to the solution). For their destruction $\mathrm{SO}_{2}$ shall be passed through the solution $\mathrm{SO}_{2}$.

- It is possible to obtain the pure water free sodium thiosulfate by reacting sulfur with sodium nitrite in formamide. This reaction quantitatively proceeds (at $80^{\circ} \mathrm{C}$ for 30 minutes) by the equation:

$$
2 \mathrm{NaNO}_{2}+2 \mathrm{~S} \rightarrow \mathrm{Na}_{2} \mathrm{~S}_{2} \mathrm{O}_{3}+\mathrm{N}_{2} \mathrm{O} \uparrow \text {. }
$$

- By dissolving sodium sulfide in water in the presence of atmospheric oxygen:

$$
2 \mathrm{Na}_{2} \mathrm{~S}+2 \mathrm{O}_{2}+\mathrm{H}_{2} \mathrm{O}=\mathrm{Na}_{2} \mathrm{~S}_{2} \mathrm{O}_{3}+2 \mathrm{NaOH}
$$

Sodium thiosulfate is soluble in water $\left(41,2 \%\right.$ at $20^{\circ} \mathrm{C}, 69,86 \%$ at $\left.80^{\circ} \mathrm{C}\right)$. At $48^{\circ} \mathrm{C}$ it is melted in its crystallization water, dehydrated about $100^{\circ} \mathrm{C}$. As it is known from the literature [50], thiosulfate $\mathrm{Na}_{2} \mathrm{~S}_{2} \mathrm{O}_{3}$ is used in medicine for allergies, arthritis, neuralgia, for detoxification of patients with alcoholic 
psychosis, for scabies treatment, caused by ticks, psoriasis and other diseases, to disinfect the intestines, as anti-inflammatory agent and burn treating substance, as antidote for poisoning by $\mathrm{As}, \mathrm{Br}, \mathrm{Hg}$ and other heavy metals, cyanides (transform them into thiocyanates), and others.

Medicinal properties of sodium thiosulfate are based on the following reaction:

$$
\mathrm{Na}_{2} \mathrm{~S}_{2} \mathrm{O}_{3}+2 \mathrm{HCI}=2 \mathrm{NaCl}+\mathrm{H}_{2} \mathrm{~S}_{2} \mathrm{O}_{3} \text {. }
$$

Thiosulfuric acid or hyposulphurous acid formed by the reaction (2.21) is unstable, it breaks down into sulphurous acid and colloidal sulfur:

$$
\mathrm{H}_{2} \mathrm{~S}_{2} \mathrm{O}_{3} \rightarrow \mathrm{H}_{2} \mathrm{SO}_{3}+\mathrm{S} \text {. }
$$

That is to say, by successive treatment of the skin with thiosulfate solution and then with the solution of the hydrochloric acid the colloidal sulfur is released that has bactericidal properties. The formed colloidal sulfur destroys parasites.

In the food industry, sodium thiosulfate is registered as a food additive E539 (acidity regulator). In analytical chemistry, it is used as a reactant in the iodometry $\left(2 \mathrm{~S}_{2} \mathrm{O}_{3}{ }^{2-}+\mathrm{I}_{2} \rightarrow \mathrm{S}_{4} \mathrm{O}_{6}{ }^{2-}+2 \mathrm{I}^{-}\right)$, as the medium for the determination of molecular weights by lowering of the freezing point (cryoscopic constant of $4,26^{\circ}$ ) [51]. In organic chemistry it is used in the synthesis of the tioorganic compounds [52-53].

In the textile and paper industry it is used for cleaning fabrics from iodine and for stabilizing and for removal the traces of the chlorine after bleaching. This process is based on the following reaction:

$$
\mathrm{S}_{2} \mathrm{O}_{3}^{2-}+4 \mathrm{Cl}_{2}+5 \mathrm{H}_{2} \mathrm{O} \rightarrow \mathrm{SO}_{4}^{2-}+8 \mathrm{Cl}^{-}+10 \mathrm{H}^{+} .
$$

In mining industry sodium thiosulfate may be used for the recovery of the silver, gold from the ores and minerals [54-55].

The basis for thiosulfate leaching is the air oxidation in acidic (acid or complex salts of copper) or an alkaline medium (ammonium thiosulfate leaching):

$$
\begin{gathered}
4 \mathrm{Au}+\mathrm{O}_{2}+8 \mathrm{~S}_{2} \mathrm{O}_{3}{ }^{2-}+4 \mathrm{H}^{+} \rightarrow 4\left[\mathrm{Au}\left(\mathrm{S}_{2} \mathrm{O}_{3}\right)_{2}\right]^{3-}+2 \mathrm{H}_{2} \mathrm{O} \\
4 \mathrm{Ag}+8 \mathrm{~S}_{2} \mathrm{O}_{3}{ }^{2-}+\mathrm{O}_{2}+4 \mathrm{H}^{+} \rightarrow 4\left[\mathrm{Ag}\left(\mathrm{S}_{2} \mathrm{O}_{3}\right)_{2}\right]^{3-}+2 \mathrm{H}_{2} \mathrm{O} \\
\mathrm{Au}+5 \mathrm{~S}_{2} \mathrm{O}_{3}{ }^{2-}+\left[\mathrm{Cu}\left(\mathrm{NH}_{3}\right)_{4}\right]^{2+} \rightarrow\left[\mathrm{Au}\left(\mathrm{S}_{2} \mathrm{O}_{3}\right)_{2}\right]^{3-}+4 \mathrm{NH}_{3}+\left[\mathrm{Cu}\left(\mathrm{S}_{2} \mathrm{O}_{3}\right)_{3}\right]^{5-} \\
\mathrm{Ag}+\left[\mathrm{Cu}\left(\mathrm{NH}_{3}\right)_{4}{ }^{2-}+5 \mathrm{~S}_{2} \mathrm{O}_{3}{ }^{2-} \rightarrow\left[\mathrm{Ag}\left(\mathrm{S}_{2} \mathrm{O}_{3}\right)_{2}\right]^{3-}+\left[\mathrm{Cu}\left(\mathrm{S}_{2} \mathrm{O}_{3}\right)_{3}\right]^{5-}+4 \mathrm{NH}_{3} .\right.
\end{gathered}
$$


Advantage of the thiosulfate leaching method over the cyanide leaching method is that there is no need to use highly toxic reagents, as well as a more complete recovery of metals from ores containing large amounts of copper and manganese. The ammonium thiosulphate leaching of gold in the presence of sulfur and ammonium sulfite can improve the recovery rate of the precious metal up to $50-95 \%$.

Sodium thiosulfate is used in photography as a fixer. Its use is based on the ability of the thiosulfate ion to transform the insoluble light-sensitive silver halides into the soluble light-insensitive complexes:

$$
\mathrm{AgHal}+2 \mathrm{~S}_{2} \mathrm{O}_{3}{ }^{2-} \rightarrow\left[\mathrm{Ag}\left(\mathrm{S}_{2} \mathrm{O}_{3}\right)_{2}\right]^{3-}+\mathrm{Hal}^{-} .
$$

In the process of obtaining of the bisulfate or ammonium persulfate from the sulfur its treatment for the removal of the hydrogen sulfide and mercaptan impurities is not required, as in parallel with the oxidation of the sulfur the oxidation of these accompanying compounds to sulfur dioxide is happening,

Ammonium sulfate may be used not only as conserving agent (in food industry it is registered as additive E517) or for bactericide mixture but also it is possible to be used in the various industries as, e.g. in agriculture as nitrogen-sulfur fertilizer that contains $21 \%$ of nitrogen in ammonium form, sulfur $-24 \%$, in viscose fiber production, in biochemistry for proteins treatment etc. The sulfur in the composition of the ammonium sulfate is necessary for nourishment of almost all agricultural crops; its presence is required in the synthesis of essential amino acids of many plants.

Potassium sulfate $\left(\mathrm{K}_{2} \mathrm{SO}_{4}\right)$. It is used as potash fertilizer, for receiving exsiccated alum, comprising a flux in metallurgy as sulfonating agent in the manufacture of dyes, in the analytic chemistry for the transformation of sparingly soluble compounds into easily soluble ones, in medicine, photography, pyrotechnics, in the manufacture of glass, soaps, inks, leather and especially in the chemical industry, where they are processed into $\mathrm{KCI}, \mathrm{K}_{2} \mathrm{CO}_{3}, \mathrm{KOH}$, $\mathrm{KNO}_{3}$, and other compounds.

Normally potassium sulfate is used in the background of phosphorus or nitrogen fertilizers. The highest increase of agricultural crops is defined at mobile potassium poor soils: peaty, floodplain, sandy loam and sod-podzolic loam soils. The plants also need the potash fertilizers at the gray forest loams, podzolized and leached black soils, humid subtropics red earth (with prolonged cultivation of the tea bush and citrus). More responsive to potassium those plants which consume large amounts of this element, such as potatoes, sugar beet, fodder roots, tobacco, flax and hemp. 
In the gray soils, brown and other types of soils the legumes, beans, a variety of perennial grasses, corn, winter cereals, buckwheat and fruit plantations are well responding to the potash. Potassium positively effects on the quality of the products that lies in the increase of the content of sugar, starch, protein (especially against the background of nitrogen ammonia fertilizer). In addition, potash fertilizers increase the resistance of plants to certain fungal diseases, while for winter grains, legumes and perennial crops they increase the frost resistance and drought tolerance.

The efficiency of the potash fertilizers depends on the content of the accompanying elements in them such as sodium, chloride and others. Thus, the potato, tobacco, grapes, lupine and other plants, i.e. the chlorine sensitive crops make better quality harvest when potassium is being added to them. Each centner of $\mathrm{K}_{2} \mathrm{O}$ added in potassium sulfate form provides the following an average yield increase of raw cotton (in centners): 1-2 cotton, sugar beets $35-40$, potatoes $20-33$ potatoes, flax fiber 1,5 , the grain of winter $3-5$, spring grain 2-3, 20-33 sown grass hay 20-33, meadow hay 8-18 [56].

The presence the sulfate ion in the fertilizer has a positive effect on the crop of the cruciferous plants (cabbage, rutabaga, turnips, etc.) and beans that consume a lot of sulfur. When heated with strong sulfuric acid the potassium sulfate forms the acid salt - potassium hydrosulfate (bisulfate):

$$
\mathrm{K}_{2} \mathrm{SO}_{4}+\mathrm{H}_{2} \mathrm{SO}_{4}=2 \mathrm{KHSO}_{4} \text {. }
$$

Heating of the mixture shall be continued until the mixture mass will become clear as water, during solidification the mass shall be split into pieces and kept in a tightly sealed container. $\mathrm{KHSO}_{4}$ above the melting point of $210^{\circ} \mathrm{C}$ transforms pyrosulfate:

$$
2 \mathrm{KHSO}_{4}=\mathrm{K}_{2} \mathrm{~S}_{2} \mathrm{O}_{7}+\mathrm{H}_{2} \mathrm{O} .
$$

\subsection{Physical and chemical properties of bactericide synthesized on the basis of ammonium persulfate and bisulfate produced from sulfur containing wastes}

\subsubsection{Bactericidal activity of preparations}

Healthcare and human welfare shall be the ultimate goal of envuronment protectiont. In this regard, one of the important tasks is to protect the human body from outside intrusion of unwanted microbes which cause various infectious diseases. 
Currently, the spread of diseases such as tuberculosis, brucellosis requires regular disinfection of the various facilities of the national economy. The main obstacle in the implementation of these measures is a scarcity of effective disinfectants, low bactericidal power,toxicity of many available substances, as well as their corrosive action to metal surfaces.

Based on a comprehensive analysis of the literature data and the results of experimental works we have found new uses for the ammonium salts. They are used to create a number of new disinfectants [57-58].

Livestock farms pretty often fall into the poor state because of tuberculosis, brucellosis and other infectious diseases. At this present situation, there is a risk of the spread of infectious diseases among the population. The main pathways for the spread of these diseases are transportation facilities where significant numbers people have to be accumulated, problems of the livestock farms and other companies that are supplying the population with basic foodstuffs, the lack of treatment facilities for the disposal of sewage and other wastes, as well as and the absence in many places proper control bacteriological indicators that should be established by the Sanitary and Epidemiological Supervision.

The elimination of the nidus of infection and prevention of the possible cases of environmental pollution shall be the most important task at the Government level. Therefore, for the purpose of decontamination of railway, motorroad and water transport facilities, network of the disinfection and washing stations and veterinary service stations, premises and territories of the storage, processing, trade and utilization of raw materials of animal origin the studies on the development of disinfectants on the basis of the oil and gas industry wastes have been conducted.

The obstacle for the implementation of measures aimed at the decontamination of various not well facilities is the scarce of effective disinfectants, low bactericidal activity and toxicity of many preparations available.

Increased bactericidal activity of a mixture of ammonium persulfate and bisulfate against Staphylococcus aureus, Mycobacterium, Brucella and other cultures are known from studies by Akbasova with students [57, 58]. On the basis of ammonium persulfate and bisulfate salts they created the new disinfectants entitled as "Zhezpen-1" and "Zhezpen-2". Bactericidal activity and the application of these preparations are described in works [57-59]. The authors on the base of production testing established their conformity with modern requirements for disinfectants, namely, they have a fairly high bactericidal action, odorless, easy soluble in water, transportable and decompose 
in the environment without wastes damaging the environment. These preparations allow the replacement of those used in livestock farming for killing Mycobacterium tuberculosis and brucellosis in the external environment which are difficult to obtain toxic preparation such as, for example, alkali and chlorinated cresols, phenols, formalin and mixtures thereof with kreolina, glutaraldehyde, caustic and soda ash, peracetic acid, bleach, sodium hypochlorite and others.

Experimentally selected on the basis of the studies of bactericidal activity of the ratios of ammonium persulphate to the ammonium bisulfate in the preparation "Zhezpen" make 1:1,5-2,5 (Table 2.1). The bactericidal action of "Zhezpen" is based on the irregularity of the normal flow of redox processes in microorganisms causing their death.

For disinfection $0,1-4,0 \%$ solutions of the preparation "Zhezpen- 1 " is used with its consumption as a spray $0,31 / \mathrm{m}^{2}$, and as solution of $0,51 / \mathrm{m}^{2}$ and $30 \mathrm{~min}$ exposure. It is harmless from the dermatological point of view, has a low toxic effect, the $\mathrm{LD}_{50}$ for white mice is $964 \mathrm{mg} / \mathrm{kg}$ of the body weight.

From Table 2.1 data it follows that $\geq 0,1 \%$ solutions of the preparation have $100 \%$ disinfectant capacity against Staphylococcus aureus culture. Relating to the mycobacteria (TB) culture $\geq 4,0 \%$ solutions have the similar capacity and relating to Brucella culture the same ie true for $\geq 0,2 \%$ solutions of the preparation.

According to the results of production tests in various farms of the agriculture complex of the country "Zhezpen-1" is recommended for wide introduction as a germicide for sanitation and disinfection of vehicles and livestock facilities. Combination of "Zhezpen-1" with the cationic surfactant of penazolin 10-16 B resulted in a new composition which has not only enhanced germicidal capacity but also has cleaning and tanning capacity for the tissue surfaces exposed to purulonecrotic decay

In this composition under the name of "Zhezpen-2" the optimal weight ratios of the components $\left(\mathrm{NH}_{4}\right)_{2} \mathrm{~S}_{2} \mathrm{O}_{8}: \mathrm{NH}_{4} \mathrm{HSO}_{4}$ :penazolin = 1:(1,5-2,5):0,02 [59].

For disinfecting solutions used drug "Zhezpen 2" in concentrations of $0,5-3,0 \mathrm{wt} . \%$, Wherein the content of the penazolin is $0,02-0,04 \mathrm{wt} \%$. In this concentration range the penazolin exhibits enhanced surface activity" it maximally lowers the surface tension of solutions to form stable foam and is an effective inhibitor of the corrosion of metals, has drying effect on the surface of animals' tissue and exhibits antiseptic properties.

"Zhezpen-2" preparation as the "Zhezpen-1" preparation, is harmless from the dermatological point of view, it has low toxicity $\mathrm{LD}_{50}=960-230 \mathrm{mg}$ / $\mathrm{kg}$ (white rats, intraperitoneally). 
Table 2.1

Characteristics of Bactericidal Properties of "Zhezpen-1" preparation (30 minutes exposure)*

\begin{tabular}{|c|c|c|c|c|c|c|}
\hline $\begin{array}{c}\text { Ratio } \\
\left(\mathrm{NH}_{4}\right)_{2} \mathrm{~S}_{2} \mathrm{O}_{8}: \\
\mathrm{NH}_{4} \mathrm{HSOO}_{4}\end{array}$ & $\begin{array}{l}\text { Disinfectant } \\
\text { concentra- } \\
\text { tion, wt \% }\end{array}$ & $\begin{array}{l}\text { Presence } \\
\text { of myco- } \\
\text { bacterium } \\
\text { tuberculo- } \\
\text { sis growth }\end{array}$ & 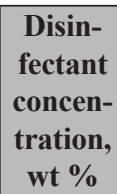 & $\begin{array}{c}\text { Pres- } \\
\text { ence of } \\
\text { Brucella } \\
\text { growth }\end{array}$ & $\begin{array}{c}\text { Disin- } \\
\text { fectant } \\
\text { concen- } \\
\text { tration } \\
\text { wt \% }\end{array}$ & $\begin{array}{c}\text { Presence of } \\
\text { staphylococ- } \\
\text { cus aureus } \\
\text { growth }\end{array}$ \\
\hline \multirow{4}{*}{$1: 1,5$} & 5,0 & ---- & 1,0 & ---- & 1,0 & ---- \\
\hline & 4,0 & ---- & 0,5 & ---- & 0,5 & ---- \\
\hline & 3,0 & -+-- & 0,2 & --- & 0,1 & --- \\
\hline & 1,0 & +++- & 0,1 & ---+ & 0,05 & --++ \\
\hline \multirow{4}{*}{$1: 2$} & 5,0 & ---- & 1,0 & ---- & 1,0 & ---- \\
\hline & 4,0 & ---- & 0,5 & $\begin{array}{l}---- \\
\end{array}$ & 0,5 & ---- \\
\hline & 3,0 & ---+ & 0,2 & ---- & 0,1 & ---- \\
\hline & 1,0 & +++- & 0,1 & ++--- & 0,05 & ---+ \\
\hline \multirow{4}{*}{$1: 2,5$} & 5,0 & ---- & 1,0 & ---- & 1,0 & ---- \\
\hline & 4,0 & ---- & 0,5 & ---- & 0,5 & ---- \\
\hline & 3,0 & -+-- & 0,2 & ---- & 0,1 & ---- \\
\hline & 1,0 & +++- & 0,1 & +--- & 0,05 & -+-- \\
\hline \multirow{4}{*}{$1: 1$} & 5,0 & ---- & 1,0 & ---- & 1,0 & ---- \\
\hline & 4,0 & ---- & 0,5 & ---- & 0,5 & ---- \\
\hline & 3,0 & -+-+ & 0,2 & -+-- & 0,1 & ---- \\
\hline & 1,0 & ++++ & 0,1 & +-+- & 0,05 & --++ \\
\hline \multirow{4}{*}{$1: 3$} & 5,0 & ---- & 1,0 & ---- & 1,0 & ---- \\
\hline & 4,0 & ---- & 0,5 & ---- & 0,5 & ---- \\
\hline & 3,0 & -+++ & 0,2 & -+-+ & 0,1 & -+-- \\
\hline & 1,0 & ++++ & 0,1 & ++++ & 0,05 & ++++ \\
\hline Control & & ++++ & & ++++ & & ++++ \\
\hline
\end{tabular}

*Note: + presence of bacteria growth; - absence of bacteria growth (with each concentration of the Disinfectant 4 parallel testing have been made).

Penazolin 10-16 B which is a part of this preparation, is a good foaming agent in acidic medium, in this connection it is possible to use disinfectant "Zhezpen-2" as the foam, which will allow considerably reduce the flow rate per unit area of the disinfected area to $0,21 / \mathrm{m}^{2}$.

At the present time, on the basis of the ammonium persulfate and bisulfate another new antibacterial composition "Bactericide" has been developed that 
has the lower corrosion and higher bactericidal capacity. "Bactericide" is a mixture of ammonium persulfate, bisulfate and a surfactant - alkylimidazoline [60].

To determine the possibility of using the surfacant alkyl imidazoline as inhibitory additive the studies have been conducted to identify the change of its surface-active properties depending on the salt composition of the solution, concentration of surfactants and temperature.

Table 2.2

Characteristics of Bactericidal Properties of "Bactericide". Preparation

\begin{tabular}{|c|c|c|c|c|c|c|c|}
\hline \multirow[b]{2}{*}{$\begin{array}{l}\text { Weight ratios } \\
\text { of }\left(\mathrm{NH}_{4}\right)_{2} \mathrm{~S}_{2} \mathrm{O}_{8} \text { : } \\
\mathrm{NH}_{4} \mathrm{HSO}_{4}: \\
\text { alkylimidazo- } \\
\text { line }\end{array}$} & \multirow[b]{2}{*}{$\begin{array}{l}\text { Ex- } \\
\text { po- } \\
\text { sure, } \\
\text { min }\end{array}$} & \multirow[b]{2}{*}{$\begin{array}{l}\text { Disin- } \\
\text { fectant } \\
\text { concen- } \\
\text { tration, } \\
\text { wt \% }\end{array}$} & \multicolumn{5}{|c|}{ Presence of Growth } \\
\hline & & & $\begin{array}{l}\text { Myco- } \\
\text { bacte- } \\
\text { rium } \\
\text { (TB) }\end{array}$ & Brucella & $\begin{array}{c}\text { Staphy- } \\
\text { lococcus } \\
\text { aureus }\end{array}$ & $\begin{array}{c}\text { Es- } \\
\text { cheri- } \\
\text { chia } \\
\text { coli }\end{array}$ & $\begin{array}{c}\text { Bakte- } \\
\text { rium } \\
\text { nekro- } \\
\text { forum }\end{array}$ \\
\hline \multirow{4}{*}{$1: 1,5: 0,02$} & 20 & 3,0 & ---- & ---- & ---- & ---- & ---- \\
\hline & 20 & 1,0 & +--- & ---- & ---- & ---- & ---- \\
\hline & 20 & 0,5 & -+++ & ---- & ---- & ---- & ---- \\
\hline & 20 & 0,1 & ++++ & ---- & -+-+ & ---- & -+-- \\
\hline \multirow{4}{*}{$1: 2: 0,02$} & 20 & 3,0 & ---- & ---- & ---- & ---- & ---- \\
\hline & 20 & 1,0 & ---- & ---- & ---- & ---- & ---- \\
\hline & 20 & 0,5 & -++- & ---- & ---- & ---- & ---- \\
\hline & 20 & 0,1 & ++++ & ---- & +--- & ---- & ---- \\
\hline \multirow{4}{*}{$1: 2,5: 0,02$} & 20 & 3,0 & ---- & ---- & ---- & ---- & ---- \\
\hline & 20 & 1,0 & ---- & ---- & ---- & ---- & ---- \\
\hline & 20 & 0,5 & +++- & ---- & ---- & ---- & ---- \\
\hline & 20 & 0,1 & ++++ & ---- & +--- & ---- & ---- \\
\hline \multirow{4}{*}{$1: 1,0: 0,02$} & 20 & 3,0 & ---- & ---- & ---- & ---- & ---- \\
\hline & 20 & 1,0 & ++-- & ---- & ---- & ---- & ---- \\
\hline & 20 & 0,5 & ++++ & ---- & ---- & ---- & ---- \\
\hline & 20 & 0,1 & ++++ & +++- & -+-+ & ---- & -++- \\
\hline \multirow{4}{*}{$1: 3,0: 0,02$} & 20 & 3,0 & ---- & ---- & ---- & ---- & ---- \\
\hline & 20 & 1,0 & ++-- & ---- & ---- & ---- & ---- \\
\hline & 20 & 0,5 & ++++ & ---- & ---- & ---- & ---- \\
\hline & 20 & 0,1 & ++++ & ++++ & ---- & ---- & ---- \\
\hline \multirow{4}{*}{$1: 2,0: 0,01$} & 20 & 3,0 & ---- & ---- & ---- & ---- & ---- \\
\hline & 20 & 1,0 & ---- & ---- & ---- & ---- & ---- \\
\hline & 20 & 0,5 & +--- & ---- & ---- & ---- & ---- \\
\hline & 20 & 0,1 & ++++ & ---- & -+-- & ---- & ---- \\
\hline
\end{tabular}


Tables 2.2 and 2.3 shows the data to determine the bactericidal capacity and optimal ratio of the components in the composition of the proposed agent "Bactericide", in which a sufficiently high disinfecting capacity is observed.

Previously conducted studies on the chemical compatibility of the components that make up the proposed disinfectant "Bactericide". Compatibility was determined based on analysis of the content of the active substances (ADV): ammonium persulfate and bisulfate in solutions containing and not containing the surfactant additives.

Experimental data suggest that the solutions containing $\geq 0,1 \%$ of the "Bactericide" preparation have 100\% disinfectant capacity against Staphylococcus aureus cultures. Concerning the mycobacteria (TB) culture solution with a concentration of $\geq 3,5 \%$ has the similar capacityactivity and in respect of Brucella culture $\geq 0,5 \%$ solutions of this preparation have the same capacity (Tables 2.2 and 2.3).

It is determined that the content of the active compound in the presence of alkylimidazoline is not reduced, i.e. the components are chemically compatible. Determination of the active compound was conducted during 24 hours with sampling for analysis after every 8 hours from the moment the alkylimidazoline additives had been added.

Table 2.3

Optimum ratios of Components in Composition of Proposed Disinfectant "Bactericide"

\begin{tabular}{|l|c|c|c|}
\hline \multirow{2}{*}{ Components } & \multicolumn{3}{|c|}{$\begin{array}{c}\text { Quantity of the components, wt. \% } \\
\text { in the proposed disinfectant agent }\end{array}$} \\
\cline { 2 - 4 } & Sample 1 & Sample 2 & Sample 3 \\
\hline Ammonium persulfate & 27,0 & 33,5 & 39,0 \\
\hline Ammonium bisulfate & 70,1 & 64,1 & 58,0 \\
\hline Alkylimidazoline & 1,2 & 0,9 & 0,7 \\
\hline
\end{tabular}

The findings indicate a high enough bactericidal power of the "Bactericide" preparation and the absence of influence on alkylimidazoline disinfectant capacity of the ammonium salts.

Using a thermal method, the functional connection of the freezing point of the solutions and the concentration of the preparation was determined (Picture 2.2). 


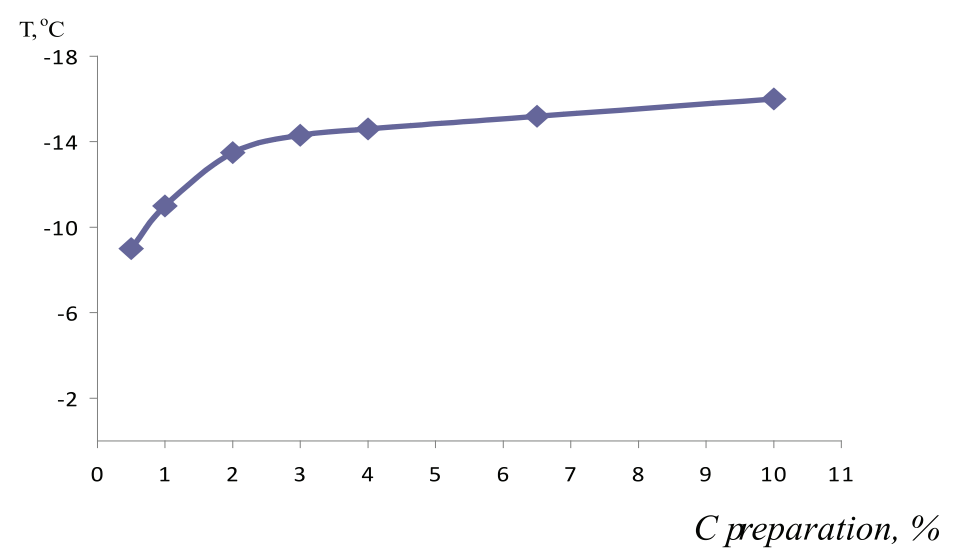

Picture 2.2. Functional Connection of Temperature of the "Bactericide" Preparation Water Solutions and its Concentration (wt\%.)

As can be seen from the experimental data shown in Picture 2.2, with the increase of the "Bactericide" preparation concentrations in the solutions there is the decrease in temperature of their freezing. For example, $0,5 \%$ solution has a freezing point of $-12,8^{\circ} \mathrm{C}$, and $7,0 \%$ solution $-14,4^{\circ} \mathrm{C}$. The bactericidal efficiency of the preparation remains at the sub-zero temperatures, which is one of its advantages over other known disinfectants as their solutions freeze at temperatures below $-5^{\circ} \mathrm{C}$.

\subsubsection{Inhibition of corrosiveness in synthesized disinfectants}

Despite of the widespread development of the industry of synthetic substances the metals still remain as the main structural material, indispensable in a number of major sectors of the industriy and agriculture.

The use of inhibitors is an economical, efficient and universal method of protection of metals from corrosion. It is successfully used in almost all sectors of the industry and agriculture and in any environments and conditions in aqueous salt solutions of different mineralization content, in solutions of mineral and organic acids and bases, in non-aqueous solutions, in heterogeneous systems such as hydrocarbon-water, under atmospheric conditions, in soils, in operation of metal items.

The rate of corrosion due to the introduction of inhibitors can be reduced practically to any desired number of folds and the degree of protection can be adjusted through them almost to $100 \%$. 
The efficiency of the inhibitor is defined both by its nature and the nature of the corroding metal. Besides, the efficiency of the inhibitor depends essentially on the conditions of corrosion, i.e. the composition and properties of corrosion environment as well as on its temperature,

The role of the corrosion process inhibitors is played by the substances belonging to various classes of organic and inorganic compounds. The nature of their relationship with the surface of the corrodible metal is different due to the diversity of substances having an inhibitory effect, protected metals and actual used corrosive environments. However, a prerequisite for any process of inhibition, regardless of the subsequent behavior of the inhibitor is its adsorption on the metal surface.

Nitrogen-containing cationic surfactants are widely used in various sectors of the industry,agriculture, in medicine and in everyday life as corrosion inhibitors, bactericidal and antiseptic preparations.

As follows from Pictures 2.3 and 2.4 the surfactant properties of cationic surfactant-alkylimidazoline depend on the salt composition of the solution, the concentration of the surfactant and temperature.

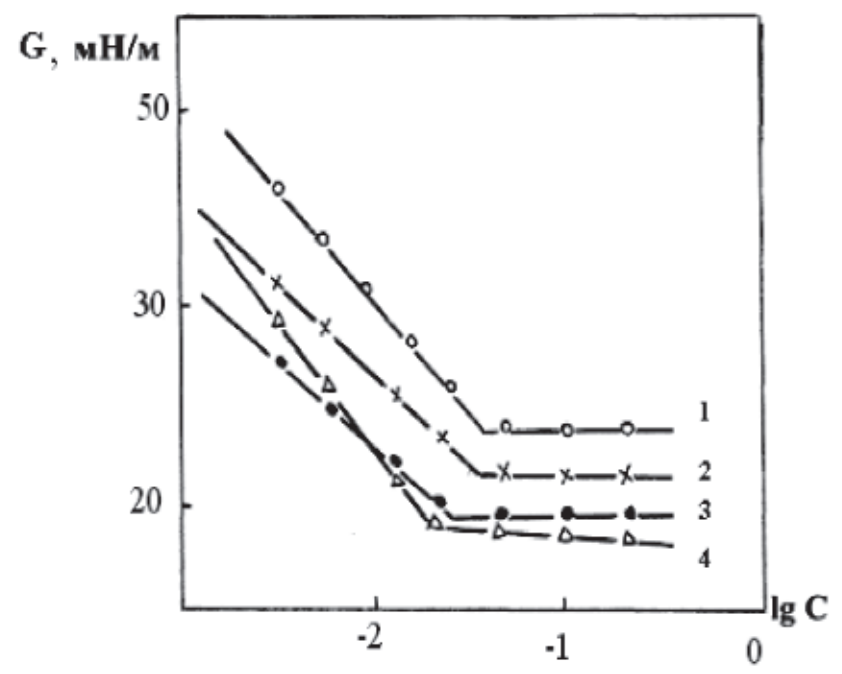

Picture 2.3. Isotherm of the surface tension

of the alkylimidazoline solution at the phase interface (298 K):

1-for "Water-Air" system; 2, 3, 4- "Bactericide-Air" system, correspondingly for 0,$1 ; 1,0 \%$ and $5 \%$-water solutions of the preparation 
As shown in Picture 2.3, with the increase of the concentration of cationic surfactant in solution the decrease in surface tension is observed. Moreover, this takes place only to a certain specific concentration of cationic surfactant in solution. Further increase of concentration of cationic surfactant does not entail the change of the surface tension probably at these concentrations a saturated monolayer is formed. Experimental data obtained in the study of surface properties show that surface activity of the test mixture also depends on the composition of the solution, i.e. alkylimidazoline surfactant adsorption capacity in the preparation "Bactericide" solution is higher than in water (Picture 2.3). For example, the critical concentration of micelle formation (CCM) for water is $34,6 \mathrm{mN} / \mathrm{m}$ for $0,1 \%$ solution of the preparation "Bactericide" is $34,4 \mathrm{mN} / \mathrm{m}$; for a $1 \%$ solution of "Bactericide" is $28,6 \mathrm{mN} / \mathrm{m}$; for $5 \%$ solution of "Bactericide" is $28,0 \mathrm{mN} / \mathrm{m}$.

It is determined that with the increase of the salt concentration the values of CMC decrease, which also points to an increase in the surface activity of the cationic surfactant - alkylimidazoline.

Thus, the findings indicate to the saving of the surface properties of studied cationic surfactants in the solutions of ammonium salts.

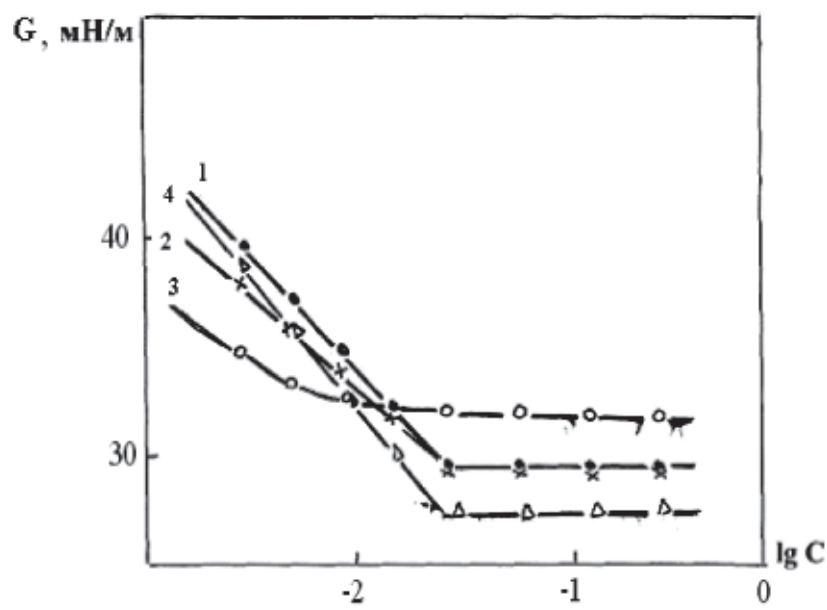

Picture 2.4. Isotherm of the surface tension of the solution alkylimidazoline, taken at different temperatures, in the "Bactericide-Air" system at 1\% concentration of the preparation in solution: $1-298 K ; 2-303 K ; 3-313 K ; 3-263 K$ 
In order to reduce the corrosive action of the proposed preparation "Bactericide" the stady was conducted by the addition of more surfactant alkylimidazoline that has surface activity. Tables 2.4-2.6 shows the results of experiments on the corrosion of metals and alloys study (the test time up to 504 hours) in various aqueous solutions of the disinfectants.

Experimental data indicate that the corrosive effect of the "Bactericide" preparation on the aluminum at concentrations above $1 \%$ is comparable to the corrosive action of solutions of bleach. And at concentrations of less than $1 \%$ its corrosive effect is far below the destructive action of bleach solutions with the same concentrations. The weight loss of aluminum in the "Bactericide" preparation solutions in comparison with the caustic soda is $2-5$ fold less and in comparison with peracetic acid it is $8-10$ fold less (Table. 2.4).

Table 2.4

The results of tests on samples of aluminum for corrosion. Inhibitor - cationic surfactants alkylimidazoline

\begin{tabular}{|c|c|c|c|c|c|}
\hline $\begin{array}{c}\text { Test } \\
\text { o. }\end{array}$ & $\begin{array}{c}\text { Concentration } \\
\text { of the prepa- } \\
\text { ration, } \%\end{array}$ & $\begin{array}{c}\text { Alkylimidazo- } \\
\text { line content in } \\
\text { the solution, } \%\end{array}$ & $\begin{array}{c}\text { Change of } \\
\text { samples } \\
\text { weight, } \mathbf{g}\end{array}$ & $\begin{array}{c}\text { Corrosion } \\
\text { value, } \mathbf{g} / \mathbf{m}^{2}\end{array}$ & $\begin{array}{c}\text { Corrosion } \\
\text { rate, } \mathbf{g} / \mathbf{m}^{2} \\
\text { hour }\end{array}$ \\
\hline 1 & 2 & 3 & 4 & 5 & 6 \\
\hline \multicolumn{5}{|c|}{ Bactericide } \\
\hline 1 & 0,1 & Without & 0,0350 & 13,9 & 0,027 \\
\hline 2 & 0,1 & $1 \cdot 10^{-4}$ & 0,0342 & 13,6 & 0,026 \\
\hline 3 & 0,1 & $5 \cdot 10^{-4}$ & 0,0325 & 12,9 & 0,025 \\
\hline 4 & 0,1 & $1 \cdot 10^{-3}$ & 0,0312 & 12,4 & 0,025 \\
\hline 5 & 0,1 & $5 \cdot 10^{-3}$ & 0,0308 & 12,2 & 0,024 \\
\hline 6 & 0,1 & $1 \cdot 10^{-2}$ & 0,0293 & 11,6 & 0,023 \\
\hline 7 & 1,0 & Without & 0,0470 & 19,0 & 0,037 \\
\hline 8 & 1,0 & $1 \cdot 10^{-4}$ & 0,0461 & 18,6 & 0,036 \\
\hline 9 & 1,0 & $5 \cdot 10^{-4}$ & 0,0447 & 18,0 & 0,035 \\
\hline 10 & 1,0 & $1 \cdot 10^{-3}$ & 0,0428 & 17,2 & 0,034 \\
\hline 11 & 1,0 & $5 \cdot 10^{-3}$ & 0,0402 & 16,1 & 0,031 \\
\hline 12 & 1,0 & $1 \cdot 10^{-2}$ & 0,0370 & 14,7 & 0,029 \\
\hline 13 & 5,0 & Without & 0,0944 & 37,0 & 0,073 \\
\hline 14 & 5,0 & $1 \cdot 10^{-4}$ & 0,0940 & 36,8 & 0,073 \\
\hline 15 & 5,0 & $5 \cdot 10^{-4}$ & 0,0934 & 36,5 & 0,072 \\
\hline 16 & 5,0 & $1 \cdot 10^{-3}$ & 0,0927 & 36,2 & 0,071 \\
\hline 17 & 5,0 & $5 \cdot 10^{-3}$ & 0,0912 & 35,6 & 0,070 \\
\hline
\end{tabular}


Continuation of table table 2.4

\begin{tabular}{|c|c|c|c|c|c|}
\hline $\begin{array}{c}\text { Test } \\
\text { № }\end{array}$ & $\begin{array}{c}\text { Concentration } \\
\text { of the prepa- } \\
\text { ration, } \%\end{array}$ & $\begin{array}{l}\text { Alkylimidazo- } \\
\text { line content in } \\
\text { the solution, } \%\end{array}$ & $\begin{array}{l}\text { Change of } \\
\text { samples } \\
\text { weight, g }\end{array}$ & $\begin{array}{c}\text { Corrosion } \\
\text { value, } \mathrm{g} / \mathrm{m}^{2}\end{array}$ & $\begin{array}{l}\text { Corrosion } \\
\text { rate, } \mathrm{g} / \mathrm{m}^{2} \\
\text { hour }\end{array}$ \\
\hline 1 & 2 & 3 & 4 & 5 & 6 \\
\hline 18 & 5,0 & $1 \cdot 10^{-2}$ & 0,0905 & 35,2 & 0,069 \\
\hline \multicolumn{6}{|c|}{ Peracetic acid. } \\
\hline 19 & 1 & - & 0,0107 & 4,2 & 0,008 \\
\hline 20 & 2 & - & 0,0486 & 19,0 & 0,037 \\
\hline 21 & 3 & - & 0,1925 & 75,3 & 0,149 \\
\hline 22 & 4 & - & 0,2257 & 88,2 & 0,175 \\
\hline \multicolumn{6}{|c|}{ Bleach } \\
\hline 23 & 0,5 & - & 0,0773 & 31,2 & 0,059 \\
\hline 24 & 1 & - & 0,0616 & 24,0 & 0,047 \\
\hline 25 & 2 & - & 0,0673 & 26,2 & 0,052 \\
\hline 26 & 4 & - & 0,0701 & 27,8 & 0,055 \\
\hline 27 & 6 & - & 0,0721 & 28,5 & 0,075 \\
\hline 28 & 8 & - & 0,0743 & 29,4 & 0,058 \\
\hline 29 & 10 & - & 0,0768 & 30,5 & 0,006 \\
\hline
\end{tabular}

Table 2.5

The results of corrosion tests of the galvanized iron samples. Corrosion Inhibitor - cationic surfactants alkylimidazoline

\begin{tabular}{|c|c|c|c|c|c|}
\hline $\begin{array}{l}\text { Test } \\
\text { № }\end{array}$ & $\begin{array}{c}\text { Concentration } \\
\text { of the prepara- } \\
\text { tion, } \%\end{array}$ & $\begin{array}{l}\text { Alkylimidazoline } \\
\text { content in the } \\
\text { solution, } \%\end{array}$ & $\begin{array}{l}\text { Change of } \\
\text { samples } \\
\text { weight, g }\end{array}$ & $\begin{array}{c}\text { Corrosion } \\
\text { value, } \mathbf{g} / \mathbf{m}^{2}\end{array}$ & $\begin{array}{l}\text { Corrosion } \\
\text { rate, } \mathrm{g} / \mathrm{m}^{2} \\
\text { hour }\end{array}$ \\
\hline 1 & 2 & 3 & 4 & 5 & 6 \\
\hline \multicolumn{6}{|c|}{ Bactericide } \\
\hline 1 & 1 & Without & 0,0081 & 3,1 & 0,006 \\
\hline 2 & 1 & $1 \cdot 10^{-4}$ & 0,0079 & 3,0 & 0,005 \\
\hline 3 & 1 & $5 \cdot 10^{-4}$ & 0,0072 & 2,7 & 0,005 \\
\hline 4 & 1 & $1 \cdot 10^{-3}$ & 0,0068 & 2,6 & 0,005 \\
\hline 5 & 1 & $5 \cdot 10^{-3}$ & 0,0060 & 2,4 & 0,004 \\
\hline 6 & 1 & $1 \cdot 10^{-2}$ & 0,0020 & 0,8 & 0,001 \\
\hline \multicolumn{6}{|c|}{ Peracetic acid } \\
\hline 7 & 1 & - & 0,0022 & 0,9 & 0,001 \\
\hline 8 & 2 & - & 0,0025 & 1,0 & 0,002 \\
\hline 9 & 3 & - & 0,0029 & 1,1 & 0,002 \\
\hline
\end{tabular}


Continuation of table table 2.5

\begin{tabular}{|c|c|c|c|c|c|}
\hline $\begin{array}{l}\text { Test } \\
\text { № }\end{array}$ & $\begin{array}{c}\text { Concentration } \\
\text { of the prepara- } \\
\text { tion, } \%\end{array}$ & $\begin{array}{l}\text { Alkylimidazoline } \\
\text { content in the } \\
\text { solution, } \%\end{array}$ & $\begin{array}{c}\text { Change of } \\
\text { samples } \\
\text { weight, g }\end{array}$ & $\begin{array}{c}\text { Corrosion } \\
\text { value, } \mathbf{g} / \mathbf{m}^{2}\end{array}$ & $\begin{array}{l}\text { Corrosion } \\
\text { rate, } g / \mathrm{m}^{2} \\
\text { hour }\end{array}$ \\
\hline 1 & 2 & 3 & 4 & 5 & 6 \\
\hline 10 & 4 & - & 0,0027 & 1,1 & 0,002 \\
\hline \multicolumn{6}{|c|}{ Beach } \\
\hline 11 & 0,5 & - & \multicolumn{3}{|c|}{ It does not corrode } \\
\hline 12 & 1 & - & 0,0004 & 1,9 & 0,003 \\
\hline 13 & 2 & - & 0,0102 & 48,4 & 0,096 \\
\hline 14 & 4 & - & 0,0139 & 66,0 & 0,130 \\
\hline 15 & 6 & - & 0,0531 & 252,1 & 0,500 \\
\hline 16 & 8 & - & 0,0620 & 294,3 & 0,584 \\
\hline 17 & 10 & - & 0,0707 & 335,6 & 0,660 \\
\hline 18 & $\mathrm{NaOH}, 2$ & - & 0,0012 & 0,4 & 0,008 \\
\hline
\end{tabular}

"Bactericide" preparation solutions have no corrosive effects on the stainless steel, and its corrosive effects on the galvanized iron is 5-6 fold lower in comparison with the effect of Bleach and 5 fold higher than corrosive action of the Peracetic acid.

Table 2.6

The results of the corrosion tests of the stainless steel samples

\begin{tabular}{|c|c|c|c|c|}
\hline $\begin{array}{c}\text { Test } \\
\text { № }\end{array}$ & $\begin{array}{c}\text { Preparation name, } \\
\text { concentration, \% }\end{array}$ & $\begin{array}{c}\text { Change of the sample } \\
\text { weight, } \mathrm{g}\end{array}$ & $\begin{array}{c}\text { Corrosion } \\
\text { value, } \mathrm{g} / \mathrm{m}^{2}\end{array}$ & $\begin{array}{c}\text { Corrosion rate, } \\
\mathrm{g} / \mathrm{m}^{2} \text { hour }\end{array}$ \\
\hline 1 & 2 & 3 & 4 & 5 \\
\hline \multicolumn{5}{|c|}{ It does not corrode } \\
\hline 1 & $1-4$ & \multicolumn{5}{|c|}{ It does not corrode } \\
\hline \multicolumn{5}{|c|}{ Bleach } \\
\hline 2 & 0,5 & 0,0002 & 0,1 & 0,0002 \\
\hline 3 & 1 & 0,0034 & 1,7 & 0,0033 \\
\hline 4 & 2 & 0,0051 & 2,1 & 0,0040 \\
\hline 5 & 4 & 0,0122 & 5,0 & 0,0090 \\
\hline 6 & 6 & 0,0291 & 13,2 & 0,0260 \\
\hline 7 & 8 & 0,0280 & 11,9 & 0,0230 \\
\hline 8 & 10 & 0,0004 & 0,2 & 0,0004 \\
\hline 9 & $\mathrm{NaOH}, 2$ & Bactericide \\
\hline \multicolumn{5}{|c|}{ It does not corrode } \\
\hline 10 & $1-5$ & \multicolumn{5}{|c|}{} \\
\hline
\end{tabular}


The conducted studies showed the feasibility of addition of the inhibiting corrosion processes surfactants to the disinfectant composition. Besides, the surfactants of the cationic nature have the bactericidal action. The "Bactericide" preparation which includes in its composition the cationic surfactant is harmless from the dermatological point of view, has the low toxic action $\mathrm{LD}_{50}=960-930 \mathrm{mg} / \mathrm{kg}$ (white rats, intragastrically).

Thus, application of the new preparation "Bactericide" as a disinfectant shall allow solving one of the important problems connected with the environmental improvement and protection of the people against infectious diseases.

\subsection{Decontamination of animal residues contaminated by infectious agents}

By the quantity of generated solid and liquid wastes, as well as the air pollution by gaseous, toxic substances the livestock enterprises are characterized as the sanitary dangerous facilities. This danger is worsening by the presence and preservation for a long time of infectious agents in an active state. For example, Mycobacterium of the tuberculosis persist in the manure or manure slurry up to a year and a half, the agents of brucellosis up to six months, and the viability of infectious diseases in the soil system is 4 or more folds longer than in the manure. Therefore, infected manure should be decontaminated before application on the soil as fertilizer.

Development of the technology for the decontamination of the manure from the sick or recovered animals and subsequent utilization with prodution of fertilizers shall be one of the urgent tasks in agriculture. In this regard, for the decontamination and utilization of the manure in the working conditions we recommended the following diagram for disinfecting of the manure slurry using solutions of the "Bactericide" preparation (Table 2.7 and Picture 2.5).

Table 2.7

Results of the disinfection of cattle manure by the "Bactericide" preparation

\begin{tabular}{|l|c|c|c|c|}
\hline \multirow{2}{*}{ Object } & \multicolumn{4}{|c|}{ Presence } \\
\cline { 2 - 5 } & $\begin{array}{c}\text { Mycobacte- } \\
\text { rium TB }\end{array}$ & Brucella & $\begin{array}{c}\text { Staphylococ- } \\
\text { cus aureus }\end{array}$ & $\begin{array}{c}\text { Escheri- } \\
\text { chia coli }\end{array}$ \\
\hline $\begin{array}{l}\text { Manure without "Bactericide" } \\
\text { treatment (control) }\end{array}$ & ++++ & ++++ & ++++ & ++++ \\
\hline $\begin{array}{l}\text { Manure treated by 3,0\% solu- } \\
\text { tion of "Bactericide" }\end{array}$ & --- & ---- & ---- & ---- \\
\hline
\end{tabular}




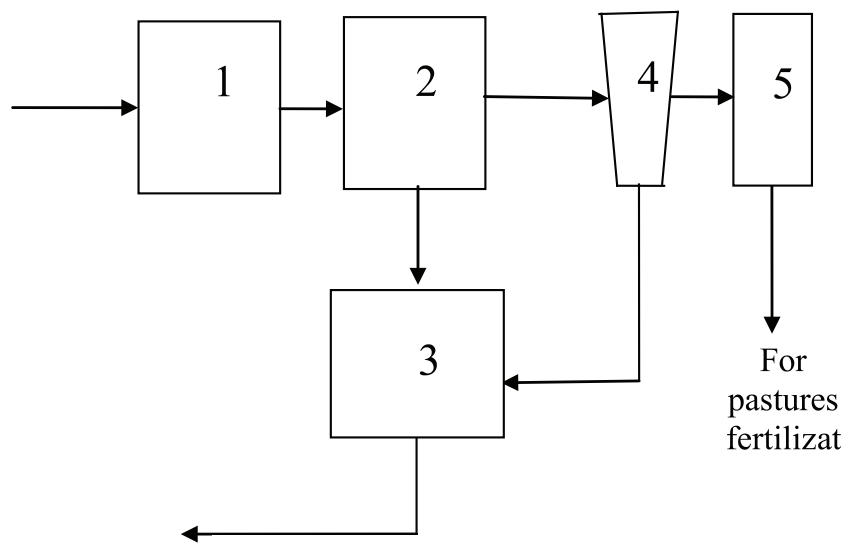

For gardens

fertilization

Picture. 2.5. Diagram of disinfection of the livestock waste:

1 -Receiving Tank; 2 - Separation Unit; 3 -Disinfection Platform; 4 - Vertical Settler; 5 - Wastes Thermal Disinfection Unit

The slurry from cattle is accumulated in the receiving tank (1), then directed to the separation unit (2), where the separation of the solid and liquid phases is happening. At platform (3) the solid part of the manure slurry is treated with $3 \%$ solution of the "Bactericide" preparation. After disinfection the manure becomes the ready-fitted fertilizer for the garden and vegetable crops. In the vertical settler (4) there is an additional separation of the phases. TIn Unit (5) waste water is further thermal treated at the temperature of 60 $70^{\circ} \mathrm{C}$. The treated water is suitable for reuse in the livestock farming complex, or can be used to fertilize pastures.

\section{CHAPTER CONCLUSIONS}

1. Process flow diagram for the production of various market products made of sulfur-containing wastes, namely ammonium salts (persulfate, sulfate, bisulfate) sodium thiosulfate, potassium sulfate, and others.

2. On the basis of the utilization of sulfur-containing wastes the new disinfectants-"Zhezpen-1" and "Zhezpen-2" have been produced, which have high bactericidal capacity against staphylococci, escherichia coli, mycobacteria and brucella, as well as microorganisms that cause purulonecrotic decay and others. 
3. The of new formulations of disinfectants with high microbicidal and low corrosivity, corresponding to modern requirements to disinfectants have been developed. The main components of the preparation "Bactericide" are ammonium persulfate and ammonium bisulfate, as well as cationic surfactants - alkylimidazolines. Compared with bleach and caustic soda that are widely used for disinfection, this preparation has less corrosivity.

4. Freezing points of aqueous solutions of germicide preparation "Bactericide" have been determined and on the basis of experimental data the possibility of using this preparation solutions for disinfecting facilities in cold seasons of the year was defined, which is one of its advantages over other known disinfectants.

5. Application of new synthesized preparations on the basis of Ammonium salts helps to solve one of the most important tasks related to the livestock rehabilitation and protection of people from catching the infectious diseases. 


\section{PRODUCTION WASTE BIOACTIVE SUBSTANCES AND THEIR USAGE}

\subsection{Characteristics of growth-stimulating substances, methods of their production}

In recent years, in the agricultural production it is clearly to observe the developed trend of increasing, and sometimes of uncontrolled use as fertilizer the wastes of steel and other industries and intensive use of different plant protection chemicals. has been has developed This approach leads to the contamination of the soil with hazard chemicals, inhibits the plants access to the necessary nutrients, thereby deteriorating the quality and reducing the amount of cultivated crop products.

In conditions of the technogenic pollution the use of environmentally friendly agricultural technologies in the practice of agricalture, namely the use of bacterial and other bio-fertilizers and growth regulators to enhance the stability and productivity of crop plants is a priority direction of the modern crop growing.

Analysis of the published data shows that excessive amounts of the pollutants released into the environment as a result of the industrial enterprises operation, reduce the yield and quality of products, have a negative impact on the growth and development of plants [61-62]. In connection with this the urgent task is to find compounds with a wide range of the positive effects.

At present we know a lot of biologically active agents that are classified as biological preparations with a wide range of positive effects [6365]. The peculiarity of their actions is that they intensify the physiological and biochemicals processes in plants and also increase resistance to stress and disease. Namely, the use of growth regulators can increase resistance of crops to climate, water, saline, osmotic, temperature stress. Besides, the growth stimulating agents may improve productivity and products quality, along with having the anti-stress effect on plants, antifungal, antibacterial and antiviral activity [66].

For many decades many research teams have been working on the creation of effective low-toxic preparations as well as on the growth stimulating and increasing crop yields preparations [67-70]. Among the variety of organic compounds, the heterocyclic nitrogen- and sulfur compounds (derivatives of pyridine N-oxide derivatives pirimidinotriazolov, phosphorylated azole 
derivatives, phenylurea et al.) which possess a number of valuable biological properties take a special place in this regard [71-73].

The authors of work [74] have demonstrated opportunity of the production of the promising physiologically active compounds: 1-(4-nitrophenyl)4-N-X and aminopirrolidones -2 and N-arylamide-3-N-arylamino-4-amino (4-nitrophenyl) butanoic acid that have growth regulating and anti-stress capacities, from available original raw materials - of pyrrolidine and amides of the carboxylic acids, as well as their use in the cultivation of wheat in the zones of risk farming ie in arid regions. These substances are characterized by the following formula:

a) 1-(4-nitrophenyl)-4-N-X-aminopirrolidone:

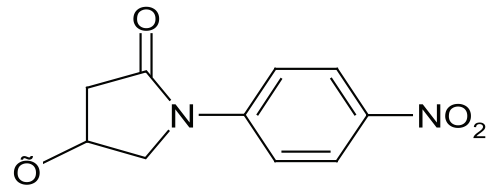

Where $\mathrm{X}--\mathrm{NH}$-cyclohexyl(I); $-\mathrm{NH}-\mathrm{C}_{4} \mathrm{H}_{9}$ (II); $-\mathrm{NH}_{2}(\mathrm{III}) ;-\mathrm{NH}-\mathrm{C}_{2} \mathrm{H}_{5}$ (IV).

b) $\mathrm{N}$ - arylamide 3-N-arylamino-4-amino-(4-nitrophenyl) butanoic acid

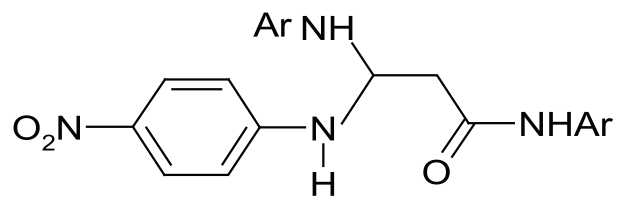

Ar: $-\mathrm{C}_{6} \mathrm{H}_{5}(\mathrm{~V}) ;-\mathrm{CH}_{2}-\mathrm{C}_{6} \mathrm{H}_{5}(\mathrm{VI})$.

$\mathrm{N}$-aryl substituted pyrrolidones can be considered $\phi s$ potential physiologically active substances. For example, 5-2-alkylpyrrolidones possess antimicrobial properties and are active against gram-positive and gramnegative microorganisms. Besides, with the increase of the alkyl radical their antimicrobial activity decreases. 1-phenyl-4-anilinpirrolidine-2 was tested in cultivation of the winter wheat, on the basis of the experimental data not only growth-regulating effec was defined but also the possibility of its use as antidote for poisoning of fish by the organophosphate pesticide of the formula [74]. 
One of the groups of materials worthy of attention are the six-membered heterocyclic compounds. In their structure, they contain the piperidine rings and they are part of many natural biological structures. As you know, pyridine bases are the main raw material for the production of the means of the chemical plant protection against weeds, pests and various diseases. Many pesticides, medicine preparations are prepared on the pyridine bases. For example, have hydrazides of isonicotinic acid and its derivatives with 4-methyl-pyridine have a high bactericidal capacity against Mycobacterium of tuberculosis [74].

For the first time the piperidine containing substance - triacetonamine was obtained synthetically from acetone and ammonia in 1874 by N. Sokolov, P. Lachinov and V. Geynttsem [75].<smiles>COC(C)=O</smiles>

In 1895. the scientists J. Guareski developed new methods of synthesis of the triacetonamine by the following condensation reactions [76]:

a) tetramethanalacetone with ammonia<smiles>COC(=O)[C@H]1NC(C)(C)CC(=O)CC1(C)C</smiles> 
b) tetramethanalacetone with various primary amines<smiles>CC(C)=CC(=O)C=C(C)CN</smiles>

tetramethanalacetone<smiles>CN1C(C)(C)CC(=O)CC1(C)C</smiles>

triatcetonmethylamine

(1-methylл-2, 2, 6, 6-tetramethyl piperidine-4-one)

Then, later V. Geynttsem also demonstrated the possibility of the synthesis of piperidine derivatives by the reaction of the diaceton amine condensation with various aromatic aldehydes (benzaldehyde, isovaleric, enentic, etc.). For example, by the reaction (3.6) of obtaining of 2,2-dimethyl-6-benzylpiperidine-4-one with an aromatic substituent in the 6-position:

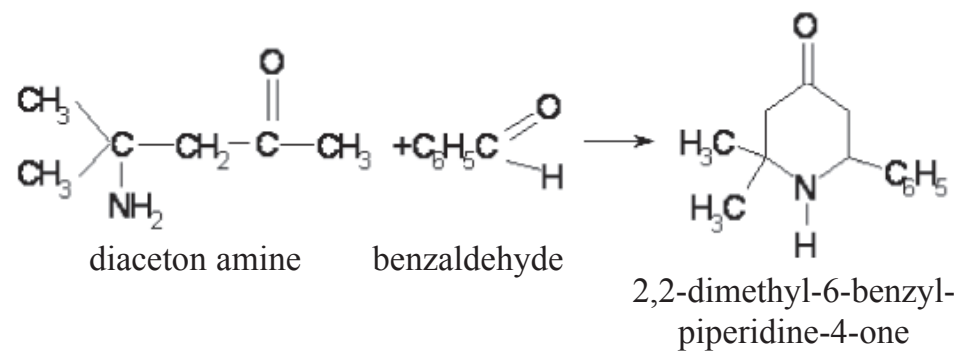

Based on the of the diaceton amine condensation with aldehydes the synthesis of a number of substances belonging to the group piperidine-4-one was carried out [77-79].

In XX and in the beginning XXI century chemistry piperidine-4-ones has grown explosively after establishing a high biological activity of this class of the compounds. It is worth noting the works of foreign scientists S. Makelveyna, P. Petrenko-Kritchenko, E. Prill, A. Cook, K. Reed, G. Bachmann, R. Baker, C. Morsch, D. Houghton and scientists of the CIS countries and Kazakhstan, which showed the possibility of producing the piperidine and its derivatives by various new and improved methods of synthesis [80]. 
Analyzing the results of scientific and research works conducted in the first half of the XX century, scientists from different countries on the synthesis of piperidine-4-ones it is possible to define the three main methods:

- method of V. Geynttsa - N. Sokolov - P. Lachinov based on reactions of the condensation of diacetonamina with aldehydes and ketones;

- method of P. Petrenko-Kritchenko based on condensation reactions of primary amines or ammonia with ketones and aldehydes;

- method by the type of Dieckmann based on the cyclization reactions of aminodicarboxylic acids esters.

Currently, all out of three of the above indicated methods the Dieckmann cyclization method has sufficiently wide practical application. The first two methods are of limited use. By the first method the introduction of a substituent into the molecule of piperidine-4-one in 6-position is possible only with two methyl groups in position 2. The disadvantage of the second method is the necessity of introducing the same substituent in positions 2 and 6.

In the years 1940-1948 Academician Ivan Nazarov and his students developed a method for the synthesis of piperidine-4-ones, based on the condensation of acetylene and its derivatives with ketones by the reaction A. Favorsky [81]. Having dicovered a new and easy way to produce different compounds of group piperidine-4-ones, the school of I. Nazarova has obtained a number of new physiologically active compounds. They synthesized a substitute of the morphine, the so called "Promedol" preparation representing propionic ester - isomer 1,2,5-trimethyl-4-phenylpiperidine-4-ol [81]. This highly active analgesic is also widely used in medicine.

A famous Kazakhstanian chemist A.Sh.Sharifkanov and his school while perfecting methods of I. Nazarov and also developing the easily performed methods for synthesizing piperidine-4-ones, for the first time obtained a number of new derivatives of piperidine series which have high biological activity [80, 82-84]. They conducted the cyclization of methoxyketones with 7-20 fold excess ammonia that allowed to increase yield of dimethylpiperidine-4-one to $68-70 \%$ and to reduce the amount of waste generated by the production. The team created a highly efficient preparation "Rihlokain" that has local analgetic action [81]. This low-toxic anesthetic registered in the Russian Federation and the Republic of Kazakhstan is available on an industrial scale, it is included in the State Register of drugs approved for use in medicine [82].

A number of highly effective analgetics were synthesized by the scientists of AB Bekturov Institute of Chemical Sciences of the Republic of Kazakhstan. For example, preparations "Prosidol" and "Kazkain", which have local 
anesthetics and anti-ryhtmic capacities, also introduced for practical use in medicine [83-84].

Biologically active substances of different nature can be obtained by the replacement of the oxime group for the amine group. As it was shown in work [86], the replacement of the oxime group at the $\mathrm{C}_{4}$ carbon atom of the piperidine for the amine group dramatically changes the property of the piperidine derivative. The toxicity of the amine-containing substance is much higher than with the oxime group, besides, it is affecting the central nervous system, causes convulsive actions.

Over the last thirty years Kazakhstan scientists on the base of the Acetylene Chemistry and Polymer Compounds Laboratory of the Institute of Chemical Sciences of the National Academy of Sciences of RK and the Laboratory of Organic Chemistry of the Kazakhstan Al-Farabi National University synthesized more than 200 preparations that have growth stimulating properties. Many of them were production tested at the Kazakhstan Scientific and Research Institute of Potato and Vegetable Farming, the Kazakhstan Scientific and Research Institute of Fruit Growing and Viculture, as well as at experimental plots of various agricultural production facilities. The preparations developed on the basis of this research are recommended and found a fairly wide application for growing vegetables, cereals and other crops at the republican level [83, 87].

As the study results showed the use of biologically active substances makes it possible to purposefully regulate major processes in the plant body, better realize the potential of the cultivar variety inherent in the genome by the nature and selection.

An important aspect of the action of growth stimulators is to increase the resistance of plants to adverse environmental factors such as high and low temperatures, lack of moisture, phytotoxic action of pesticides, disease susceptibility. As it is known from the literature using a number of growth stimulators while preparing the seeds for sowing increases vigor and germination, prevents the spread of diseases and pests by the seed materials, creates for the coming up underground seedlings improved nutrition contributes to early ripening and increase of the crop [88].

Preparation of new compounds and the development of compounds that have a complex of useful properties, and the determination of how their properties depend on the ratios of composite components is sufficiently serious and time-consuming task. In this regard, conducting of the synthesis of new conducting bioactive substances based the use the production wastes as the raw feedstockshall be of particular interest. The solution of these problems, on the one hand, makes it possible to eliminate the negative environmental situation, 
which occurs during storage, on the other hand, reduces the cost of the synthesis process, providing a more efficient use of scarce and non-renewable natural resources, replacing the primary raw material for the secondary raw materials.

\subsection{Sinthesis of biologically active compounds of piperidine series from production wastes and usage of these compounds for environmental improvement}

The study of our team had been focused on developing of the methods for producing of biologically active compounds of the piperidine series with the use of the production wastes of the coke-chemical and oil industries.

The possibility of recycling the slurry waste produced at JSC "Alash" (formerly JSC "Carbide", city of Temirtau) company during the production of acetaldehyde from calcium carbide. The main useful component in the waste is crotonaldehyde.

Based on the scientific and production importance, our main goal was to produce the crotonaldehyde $\left(\mathrm{CH}_{3}-\mathrm{CH}=\mathrm{CH}-\mathrm{CHO}\right)$ from the waste, then to obtain therefrom the piperidines and further based on them, i.e. on the basis of local raw materials revealing the possibility of the of synthesis of biologically active compounds.

According to the proposed diagram of the crotonaldehyde is recovered from the crotonaldehyde containing waste by extraction using benzene as an extractant. The recovered crotonaldehyde further with the help of anhydrous zinc chloride (catalyst) is converted to 1,3 dichloro-ethers (intermediate product), then in the presence of ammonia without recovering from the system, the process of their cyclization is carried out to obtain piperidines (Picture 3.1).

Piperidine synthesis is based on the reactions that are presented below:

$$
\mathrm{CH}_{3} \mathrm{CH}=\mathrm{CHCHO}+\mathrm{HCl} \stackrel{\mathrm{ROH}}{\longrightarrow}
$$

(1)

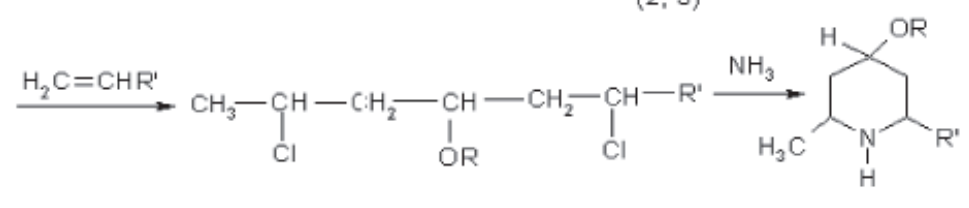

$(4-6)$

$$
\begin{array}{ll}
R^{\prime}=C_{3} H_{7}, & R=C_{3}(4,7) \\
R^{\prime}=C_{4} H_{9} . & R=C_{2} H_{5}(5,8) \\
R^{\prime}=C_{4} H_{9}, & R=C_{3}(6,9)
\end{array}
$$




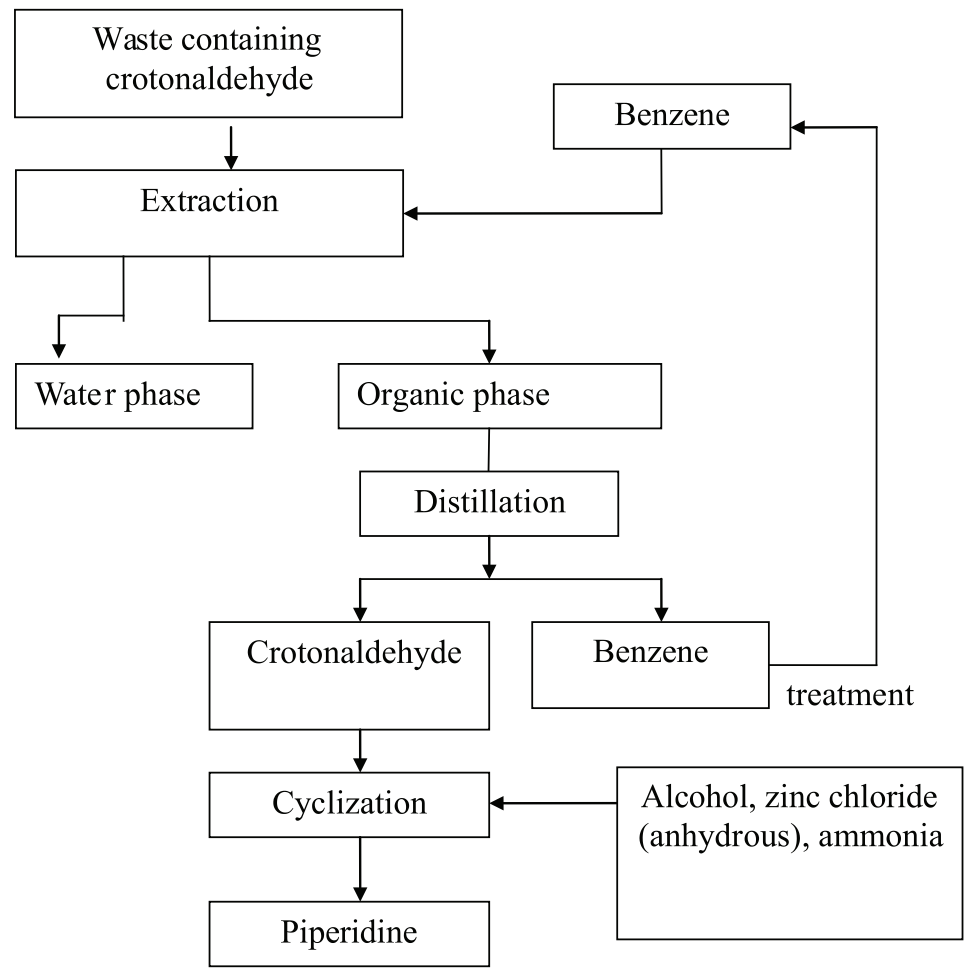

Picture 3.1. Process flow diagram of the considered wastes and other similar wastes processing to produce piperidines

From the resulting piperidine the new biologically active compounds have been synthesized, namely, the benzoic ester oxime hydrochloride 1-methylpiperidine-4-one (code name Alt-6) and 1-(2-methylpyridine-5-yl) ethyl-2,5dimethylpiperidine-4-one (code name Alt-7).

The Process Flow Diagram illustrating the methods of production of the preparations Alt-6 and Alt-7, respectively, are shown in Pictures 3.2 and 3.3

The method of the synthesis of the oxime ester hydrochloride benzoic 1-methylpiperidine-4-one (Alt-6).

Drops of 12,6 (0,09 mol) of freshly distilled benzoyl chloride were added to the mixture of $5 \mathrm{~g}(0,03 \mathrm{~mol})$ of oxime hydrochloride 1-methylpiperidin-4-one and $2,37 \mathrm{~g}(0,03 \mathrm{~mol})$ of pyridine. The mixture is heated to 
a temperature of $85-90^{\circ} \mathrm{C}$ and stirred for 4 hours. After chilling, the product is precipitated with dry ether and recrystallized from dry acetone. The reaction yielded with $6,2 \mathrm{~g}$ of benzoic ester oxime 1-methylpiperidin-4-one, which is $75,6 \%$ of the theoretically possible. Melting point of the obtained compound is $228-229^{\circ} \mathrm{C}, R_{f}=0,38$ (benzene: butanol $=3: 1$ ). The obtained compound is a white powder soluble in water.

1 - methylpiperidine chlorid- 4 - one $(1 \mathrm{~mol})+$ solution of hydroxylamine hydro ( 1 mole) in absolute ethanol + pyridine (3 mol)

Heating during 3 hours at $\mathrm{T}=85-90^{\circ} \mathrm{C}$

Oxime hydrochloride 1 - methylpiperidine - 4 - one (1 mol) + pyridine ( 1 mol) of benzoyl chloride + (3molya)

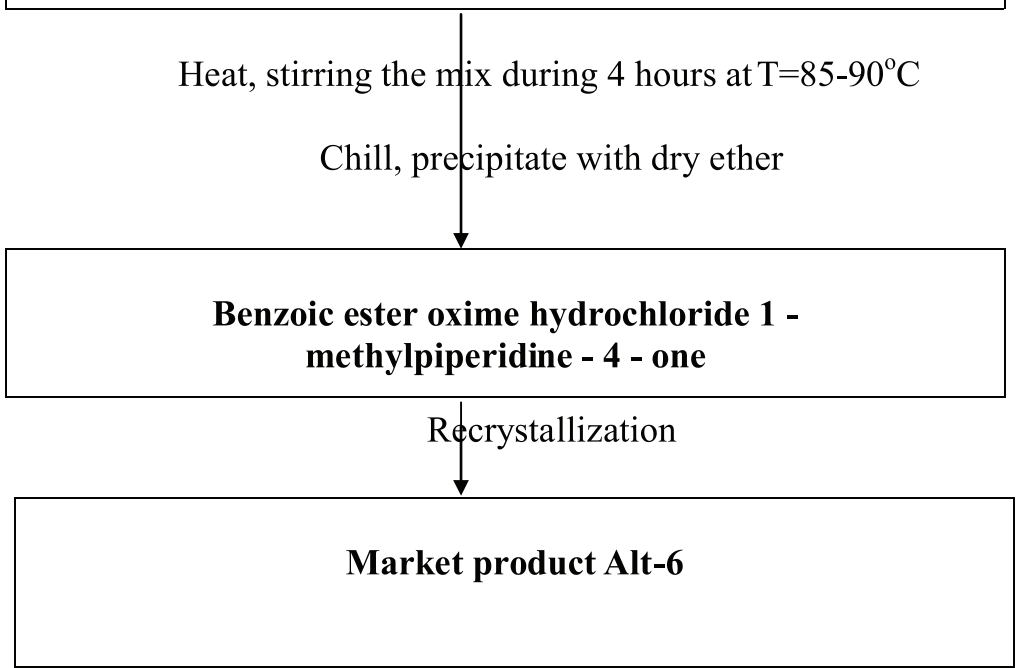

Picture 3.2. Process Flow Diagram of preparation Alt - 6 production 
The synthesis of the piperidine derivative is carried out on the basis on the following transformations:

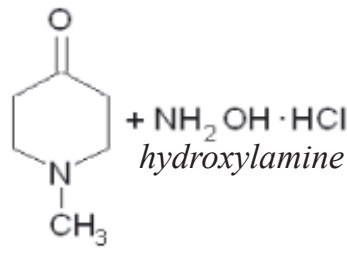

1-methylpiperidine4-one
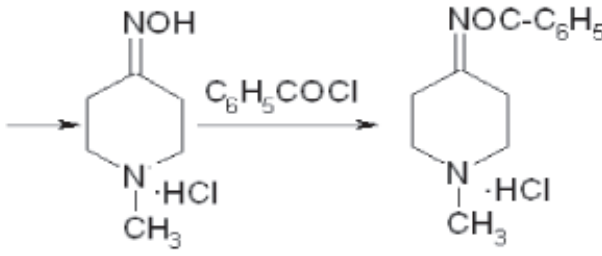

The product was identified by IR spectroscopy and elemental analysis. In the IR spectrum the bands that are characteristic for carbonyl group $\mathrm{C}=\mathrm{O}$ disappear, absorption bands appear in the $1650,1640 \mathrm{~cm}^{-1}$ range, which inhere to the linking $\mathrm{C}=\mathrm{N}$, and also the absorption bands of stretching vibrations of $\mathrm{C}-\mathrm{H}$ of the phenyl ring in 3570 , and $3550 \mathrm{~cm}^{-1}$, absorption bands of the valent linking $\mathrm{C}-\mathrm{C}$, bonds of the aromatic ring at $1565,1515,1445$ and $1435 \mathrm{~cm}^{-1}$ are observed. The observed in the IR spectrum absorption bands at $1135 \mathrm{~cm}^{-1}$ we assigned to stretching vibration of $\mathrm{C}-\mathrm{O}$ linking, $3080 \mathrm{~cm}^{-1}$ to $=\mathrm{CH}$, and the band at $1735 \mathrm{~cm}^{-1}$ to the stretching vibrations of carbonyl group $\mathrm{C}=\mathrm{O}$.

Based on the elemental analysis and by calculations the following empirical formula was made for the obtained intermediate oxime 1-methylpiperidin4-one $-\mathrm{C}_{6} \mathrm{~N}_{13} \mathrm{~N}_{2} \mathrm{OCl}$ and final product of benzoic ester oxime hydrochloride 1-methylpiperidin-4-one $-\mathrm{C}_{13} \mathrm{~N}_{17} \mathrm{~N}_{2} \mathrm{O}_{2} \mathrm{Cl}$.

The determined proportions of the main elements in the compounds are as follows:

a) $\mathrm{C}_{6} \mathrm{~N}_{13} \mathrm{~N}_{2} \mathrm{OCl}$

based on the calculation, $\%$ : carbon $-43,77$, hydrogen $-7,90$, halogen $-21,54$; based on microanalysis, $\%$ : carbon $-43,44$, hydrogen $-7,56$, halogen $-23,03$.

b) $\mathrm{C}_{13} \mathrm{~N}_{17} \mathrm{~N}_{2} \mathrm{O}_{2} \mathrm{Cl}$

based on the calculation, \%: carbon - 58,10, hydrogen $-6,37$, halogen $-13,19$; based on microanalysis, $\%$ : carbon $-58,07$, hydrogen $-6,56$, halogen $-13,30$.

$\mathrm{C}_{6} \mathrm{~N}_{13} \mathrm{~N}_{2} \mathrm{OCl}$ melts at $\mathrm{T}(231-232)^{\circ} \mathrm{C}$, this substance is of white color, practical output is not less than $88,5 \%$. 
$\mathrm{C}_{13} \mathrm{~N}_{17} \mathrm{~N}_{2} \mathrm{O}_{2} \mathrm{Cl}$ melts at $\mathrm{T}(228-229)^{\circ} \mathrm{C}$, has a white color, this crystalline substance is soluble in water.

Process of the synthesis at laboratory conditions of $\mathrm{C}_{6} \mathrm{~N}_{13} \mathrm{~N}_{2} \mathrm{OCl}$ and $\mathrm{C}_{13} \mathrm{~N}_{17} \mathrm{~N}_{2} \mathrm{O}_{2} \mathrm{Cl}$ is presented in more detail works [8-9].

1 - methyl 5-vinylpyridine (1 mole) - 2,5 - dimethylpiperidine - 4 - one (1 mol) + methanol (4 moles) + acetic acid to $\mathrm{pH}=4$

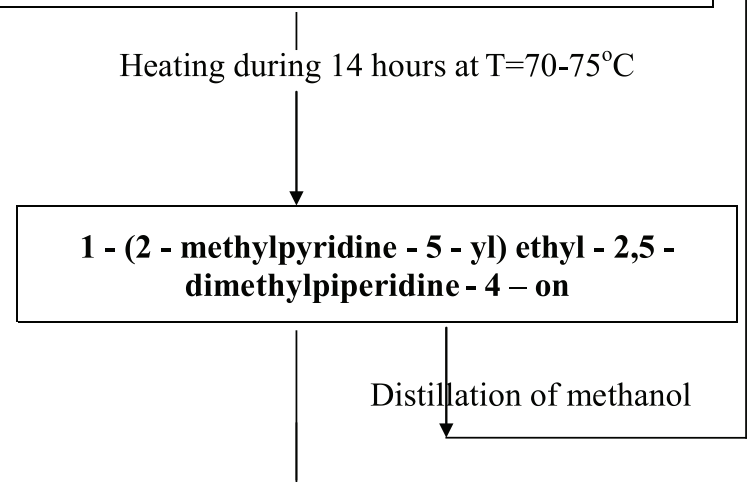

Neutralize with soda solution, and distilled water

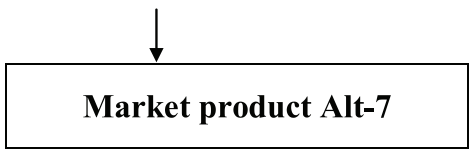

Picture 3.3. Process flow diagram of preparation ALT-7 production

The method of the synthesis of 1-(2-methylpiperidine-5-yl)ethyl-2,5-dimethylpiperidine-4-one (Alt-7).

Drops of 4,6 $\mathrm{ml}(0,038 \mathrm{~mol})$ of 2-methyl-5-vinylpyridine shall be added while stirring to a mixture of $5 \mathrm{~g}(0,038 \mathrm{~mol})$ of 2,5-dimethylpiperidine-4-one and $10 \mathrm{ml}$ of methanol and then acetic acid shall be added until $\mathrm{pH}=4$. The mixture shall be heated at $\mathrm{T}(70-75)^{\circ} \mathrm{C}$ in the water bath for 14 hours. Monitoring over the reaction is carried out by thin layer chromatography (TLC). Methanol shall be distilled from the solution and the mixture shall be neutralized with sodium carbonate solution. The water layer shall be distilled to $1 / 3$ part, the mixture shall be treated by the column chromatography method using as adsorbent $\mathrm{Al}_{2} \mathrm{O}_{3}$. 
The determined proportions of the main elements in the synthesized compounds $\left(\mathrm{C}_{15} \mathrm{H}_{22} \mathrm{~N}_{2} \mathrm{O}\right)$ are as follows:

based on calculations in \%: Carbon - 73,10, Hydrogen - 8,90, Nitrogen - 11,40;

based on microanalysis in \%: Carbon - 73,45, Hydrogen - 9,00, Nitrogen - 11,35.

The synthesis is based on the following below reation (3.9):

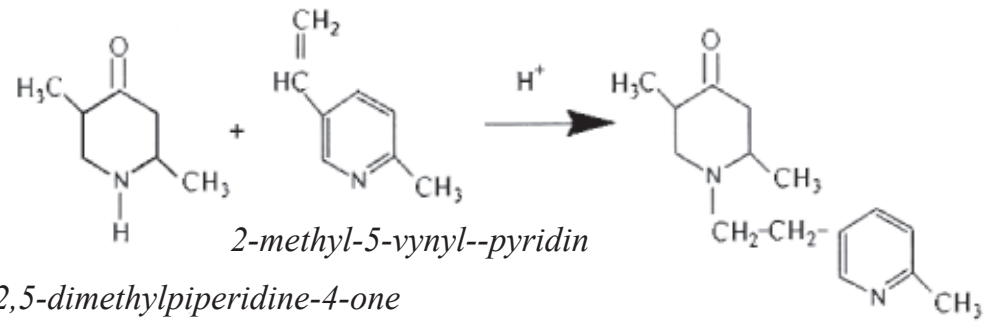

2,5-dimethylpiperidine-4-one

1-(2-methyl-pyridin-5-yl)

ethyl-2,5- dimethylpiperidine-4-one

In IR spectra of Alt-7 the absorption bands are observed that are characteristic for vibrations of the pyridine ring at $1465-1600 \mathrm{~cm}^{-1}$ for $\mathrm{C}-\mathrm{N}$ at $720 \mathrm{~cm}^{-1}$, the stretching vibrations of the carbonyl group $\mathrm{C}=\mathrm{O}$ at $1720 \mathrm{~cm}^{-1}$.

\subsubsection{Synthesis of biologically active compounds of piperidine series with usage of oil industry sulfur wastes}

The second half of the XX century was marked by intensive research in the Chemistry of sulfur - one of the most accessible elements of the periodic system.

Elemental sulfur has a high reactivity. It easily reacts with both organic and inorganic compounds to form a number of valuable market products. This was the basis for the development of the Chemistry and chemical technology of inorganic and organic sulfur-containing compounds, including polymers [89-93].

Sulfur easily dissolves in piperidine, chemically reacts with it. It reacts with the saturated aliphatic and aromatic hydrocarbons, dehydrogenates them. These reactions are in the basis of many industrial technologies for production of the asphalt like substances, polymeric sulfides, butadiene, thiophene, carbon disulfide and others. At high temperatures, interacting with alkanes, sulfur forms mercaptans and polysulfide.

Much attention is paid to the synthesis of aromatic polymers on the basis of elemental sulfur. A number of new paramagnetic polymers was obtained. 
They have semiconducting properties, as well as at the same time they have inhibitory properties for the processes of the thermal oxidative degradation of polyesters [94-95]. On the basis of elemental sulfur polycondensation with substituted aromatic hydrocarbons a number of heat-resistant polymers suitable for making coatings, films, fibers, engineering plastics, stabilizers, lubricants, rubbers and rubbers, ion-exchange resins and crosslinking agents was synthesized [89, 95].

Oxides, halides, oxo halides and other sulfur compounds are also widely used for synthesis of many types of polymers. Thus, for example, by copolymerizing sulfur oxide $\left(\mathrm{SO}_{2}\right)$ with dienes hydrocarbons or vinyl series monomers obtained polysulfones were obtained. Sulfur monochloride $\left(\mathrm{S}_{2} \mathrm{Cl}_{2}\right)$, sulfur dichloride $\left(\mathrm{SCl}_{2}\right)$, oxo halides $\left(\mathrm{SOCl}_{2}\right)$, sulfuryl chloride $\left(\mathrm{SO}_{2} \mathrm{Cl}_{2}\right)$ have been used for the synthesis of polyarylene sulfides, polyphenylene oxide sulfides, poly - (bis-n-phenylenediamine sulfoxide and poly-1,4-phenylenesulfoxide respectively $[89,95]$.

Synthesis of 1-methyl-4- (2-tiopikolinamino) - piperidine (Alt-S). According to the literature data for the preparation of 4-aminopiperidine the reaction of the reduction of oximes to amines is used or the catalytic process, or lithium aluminum hydride [96-97], and also aminopyridines [98], nicotinic acid and its derivatives [99]. There are established methods for the preparation of 4-aminopiperidine substituted by halogen atom in the 4-halogen piperidine with ammonia and also from piperidin-4-ones by carrying out a reductive amination reaction in the presence of a nickel catalyst [100].

We carried out the synthesis of 1-methyl-4-aminopiperidine by the reduction of the oxime (1-methylpiperidine-4-one) with the help of sodium metal in absolute ethanol. The initial oxime was synthesized by easiest and most acceptable method from piperidine and hydroxylamine salt.

Process of the synthesis of the base of 1-methyl-piperidine-4-one.

Put $4 \mathrm{~g}(0,035 \mathrm{~mol})$ of 1-methylpiperidine-4-one In a three-necked flask. With constant stirring, add drops of 0,035 moles $(2,5 \mathrm{~g})$ of hydroxylamine hydrochloride into $10 \mathrm{ml}$ of absolute ethanol and $7 \mathrm{ml}$ of pyridine. The resulting mixture shall be heated during 3 hours at Temperature of $(85-90)^{\circ} \mathrm{C}$. The reaction shall be monitored by TLC on alumina oxide. Then the resulting deposit that represents the oxime hydrochloride 1-methyl-piperidine-4-one shall be filtered off, recrystallization shall be carried out with absolute alcohol. Further the oxime hydrochloride is reacted with a saturated sodium carbonate solution to obtain the base for oxime 1-methyl-piperidine-4-one. 
Reactions which are the basis for the synthesis of base for 1-methyl-piperidin-4-one are given below:

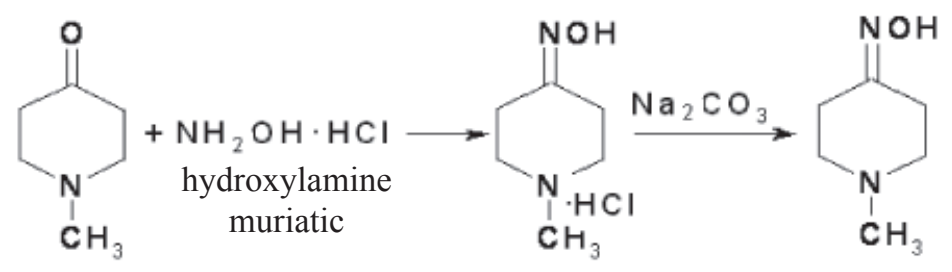

1-methylpiperidine- oxime hydrochloride

base of oxime 4-one 1-methylpiperidine-4-one 1-methylpiperidine-4-one

Synthesis of 1-methyl-4-aminopiperidine based on the reaction:

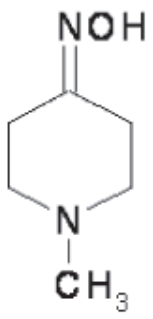

Base of oxime

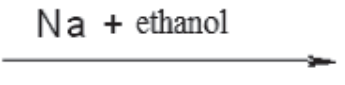<smiles>CN1CCC(N)CC1</smiles>

1-methy4-aminopiperidine

1-methyl-piperidine-4-one

For the carrying out the reaction of (3.11) $7 \mathrm{~g}$ of sodium metal in the form of small pieces shall be gently introduced to a boiling solution of $4 \mathrm{~g}$ $(0,006 \mathrm{~mol})$ the of oxime base 1-methyl-piperidine-4-one in $60 \mathrm{ml}$ of absolute ethyl alcohol, After 4 hours of boiling the alcohol shall be distilled off from the reaction mixture, then it is cooled to room temperature and $100 \mathrm{ml}$ of distilled water shall be added This should be followed by the repeated extraction by chloroform. The extract shall be dried by calcined sodium sulfate. After distilling off the solvent, the residue shall be distilled in vacuo, the resulting product is 1-methyl-4-aminopiperidine (Picture 3.4).

Process of the synthesis of 1-methyl-4- (2 -thio-picoline-amino) piperidine. In a flask equipped with a mechanical stirrer, thermometer and reflux condenser a mixture of $5 \mathrm{~g}(0,045 \mathrm{~mol})$ of 1-methyl-4-aminopiperidine, 4,1 $\mathrm{g}(0,045 \mathrm{~mol})$ B-picoline and 4,3 g $(0,135 \mathrm{~mol})$ of sulfur shall be placed. 
The reaction shall be conducted for 15 hours at temperature of $(145-150)^{\circ} \mathrm{C}$ controlling TLC method on free layer of aluminum oxide with a solvent mixture of benzene-acetone at their ratio of 5:1. After the reaction the product shall be extracted with chloroform as the extractant. Drying of the extract shall be carried out using calcined magnesium sulfate. After carrying out the extraction process, the solvent is distilled off and the resulting product - 1-methyl4-(2-thio-picoline-amino) piperidine.

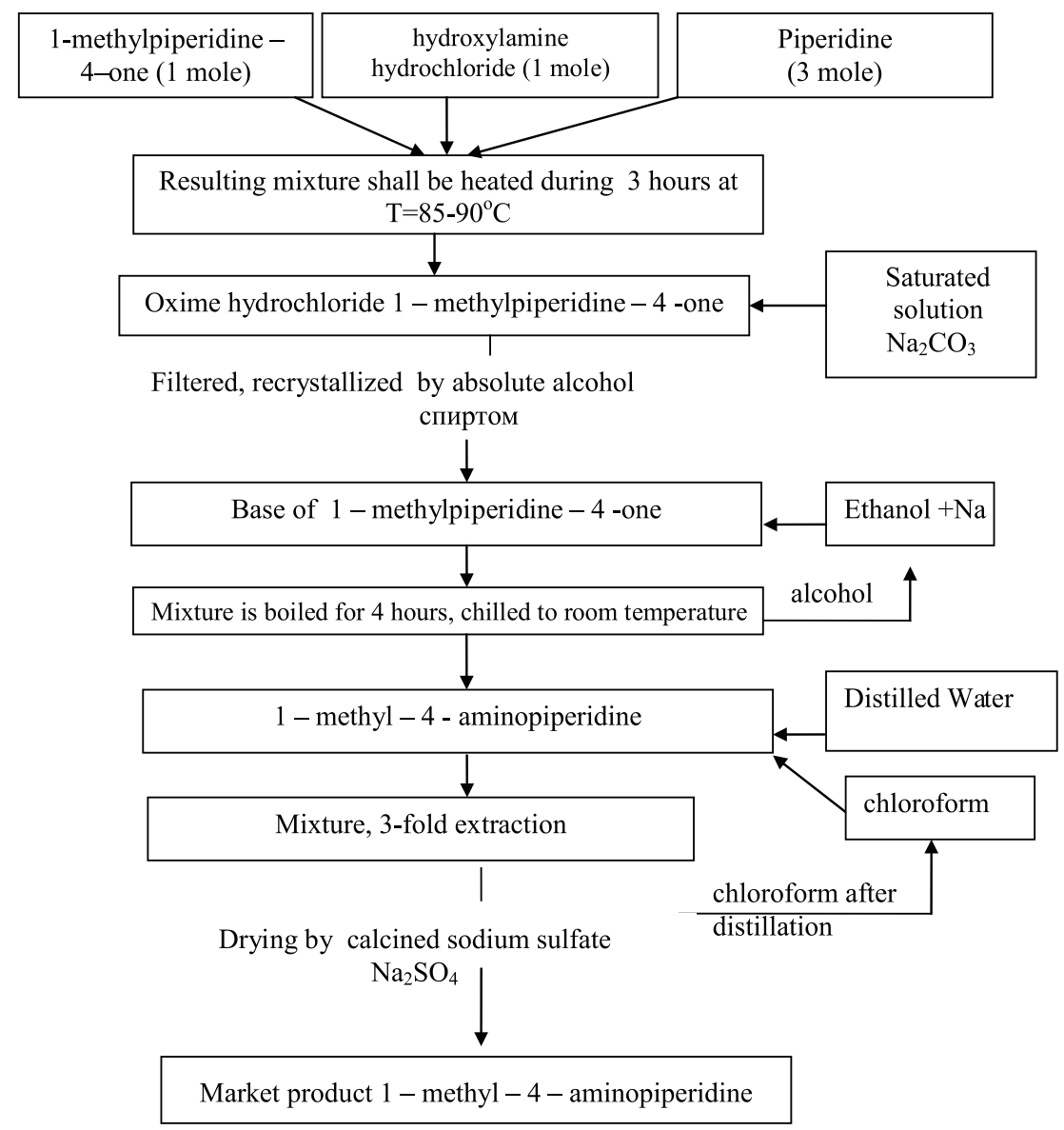

Picture 3.4. Process flow diagram of 1-methyl-4-aminopiperidine production 
In this case the variant of Vilgerodt-Kindler reaction was used and the conversion of the methyl group of the nitrogen heterocyclic B-picoline with participation of the sulfur into the thioamide group was implemented. To carry out this reaction the elemental sulfur formed in the oil industry in the form of waste was used as well as 1-methyl-4-aminopiperidine obtained from crotonaldehyde containing waste (Picture 3.5).

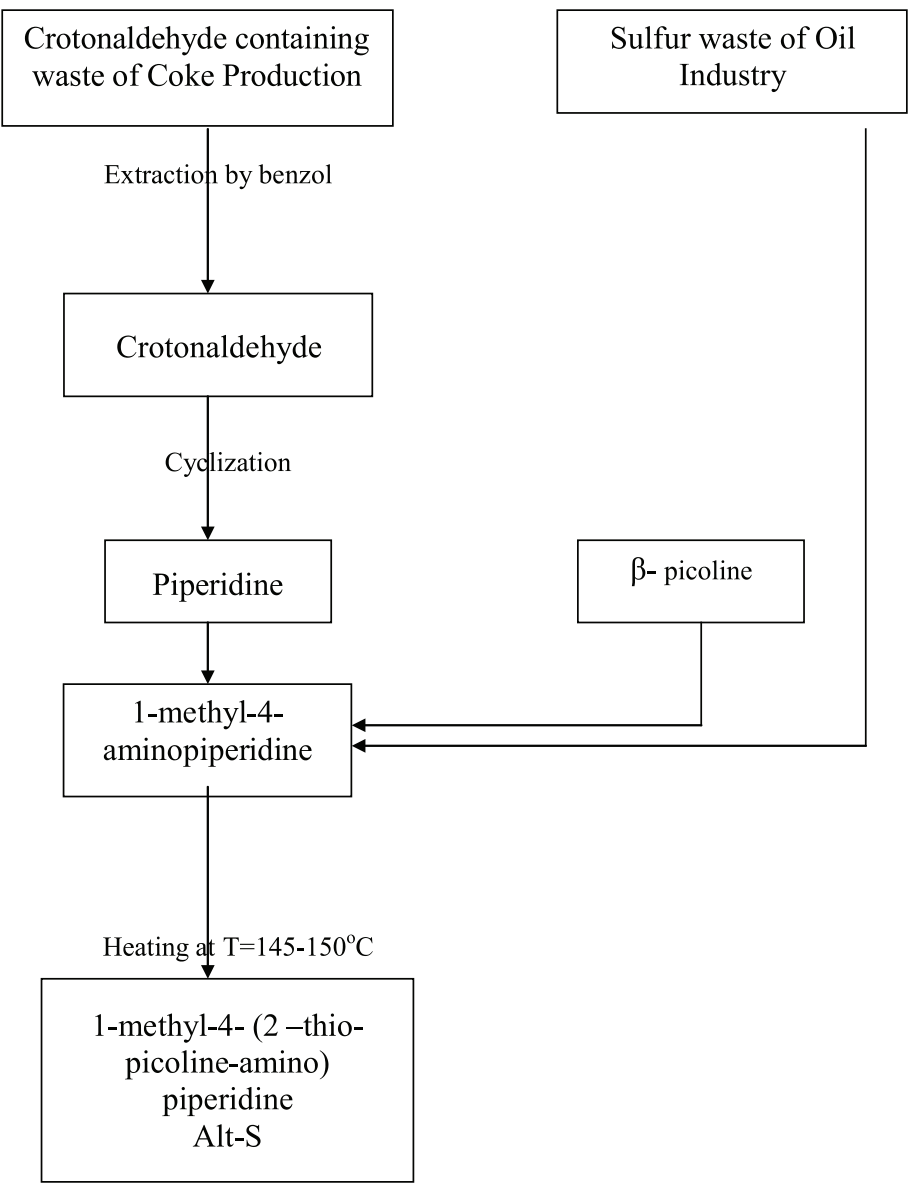

Picture 3.5. Process Flow Diagram of Alt-S production from Oil and Coke Industries waste products 
Reaction of the synthesis of 1-methyl-4-(2 -thio-picoline-amino) piperidine goes by the following scheme with output of the final product of about $75,5 \%$ of theoretical:

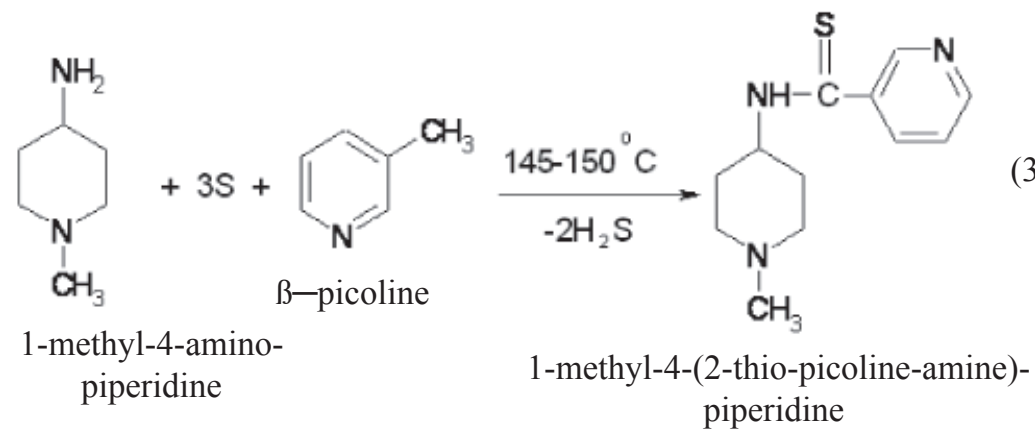

The molar ratio of the initial materials with consideration of impurities corresponded to the above reaction (3.12), i.e. 1-methyl-aminopiperidine: sulfur: $\beta$-picoline $=1: 3: 1$. The reaction time was 15 hours, the reaction was monitored using thin layer chromatography (TLC). 1-methyl-4- (2-thiopicoline-amine) - the piperidine has a light yellow color, readily soluble in water, melting point is $(115-117)^{\circ} \mathrm{C}$.

The physical, physicochemical, chemical properties, composition and the presence of various structural units derived from infrared (IR) spectroscopy and other tests are shown in Tables 3.1 and 3.2.

The structures of the intermediate and final products are proved by IR spectroscopy data. The IR spectra were recorded on the device Specord-IR-75 in the range of $4000-400 \mathrm{~cm}^{-1}$.

The IR spectra of the compound (3) in contrast to the IR spectra of compound (1) the bands characteristic for carbonyl group $\mathrm{C}=\mathrm{O}$ are not detected, but there are strong bands of $\mathrm{C}=\mathrm{N}$ group in the range of $1650 \mathrm{~cm}^{-1}$ [100].

In the spectra of the compound (3) at $2960 \mathrm{~cm}^{-1}$ absorption bands of methyl groups are present, and at $3570 \mathrm{~cm}^{-1}$ the broad band is determined indicating the presence of an associated hydroxyl group.

In the IR spectra of 4-aminopiperidine the hydroxyl group absorption bands in the $3570 \mathrm{~cm}^{-1}$ disappear, the deformation and stretching vibrations of the amine group in $1560 \mathrm{~cm}^{-1}$ and $3490 \mathrm{~cm}^{-1}$ come up. Thus, based on the data of IR spectroscopy the presence of the $\mathrm{C}=\mathrm{S}, \mathrm{C}-\mathrm{N}, \mathrm{N}-\mathrm{C}=\mathrm{S}$ links in 1-methyl-4- (2-thio-picoline-amine) piperidine is proved. 
Section 3

Table 3.1

Physico and chemical constants,

the data of elemental analysis of the synthesized compounds

\begin{tabular}{|c|c|c|c|c|c|c|c|}
\hline \multirow{2}{*}{$\begin{array}{c}\text { Gross } \\
\text { formula }\end{array}$} & \multirow{2}{*}{$\begin{array}{c}T_{\text {boil }},{ }^{\circ} \mathrm{C} \\
\text { (Mmhg.), } \\
T_{\text {melt }},{ }^{\circ} \mathrm{C}\end{array}$} & \multirow{2}{*}{$n^{20 \mathrm{D}}$} & \multicolumn{3}{|c|}{ Found/calculated, \% } & \multirow{2}{*}{$\begin{array}{c}\mathbf{R}_{\mathrm{f}} \text { benzene- } \\
\text { butanol, } \\
3: 1\end{array}$} & \multirow{2}{*}{$\begin{array}{c}\text { Yield, } \\
\%\end{array}$} \\
\hline & & & $\mathbf{C}$ & $\mathbf{H}$ & Hal & & \\
\hline 1 & 2 & 3 & 4 & 5 & 6 & 7 & 8 \\
\hline $\mathrm{C}_{6} \mathrm{H}_{13} \mathrm{~N}_{2} \mathrm{OCl}$ & $230-232$ & - & $\frac{43,54}{43,77}$ & $\frac{7,69}{7,90}$ & $\frac{21,33}{21,54}$ & 0,52 & 88,5 \\
\hline $\mathrm{C}_{6} \mathrm{H}_{12} \mathrm{~N}_{2} \mathrm{O}$ & $124-125$ & - & $\frac{56,09}{56,22}$ & $\frac{9,63}{9,44}$ & - & 0,73 & 75,4 \\
\hline $\mathrm{C}_{6} \mathrm{H}_{13} \mathrm{~N}_{2}$ & $83-87$ & 1,473 & $\frac{63,14}{63,37}$ & $\frac{11,83}{11,58}$ & - & 0,61 & 43,6 \\
\hline $\mathrm{C}_{12} \mathrm{H}_{17} \mathrm{~N}_{2} \mathrm{~S}$ & $115-117$ & - & $\frac{64,98}{65,23}$ & $\frac{7,69}{7,70}$ & $\begin{array}{l}\frac{14,80}{14,52} \\
\text { cepa }\end{array}$ & 0,86 & 75,5 \\
\hline $\mathrm{C}_{13} \mathrm{H}_{17} \mathrm{~N}_{2} \mathrm{O}_{2} \mathrm{Cl}$ & $228-230$ & - & $\frac{58,07}{58,10}$ & $\frac{6,56}{6,37}$ & $\frac{13,30}{13,19}$ & 0,40 & 89,2 \\
\hline
\end{tabular}

Table 3.2

The length of the absorption bands (v) for different links between the atoms in the IR spectra of compounds $\mathrm{cm}^{-1}$

\begin{tabular}{|c|c|c|c|c|c|c|c|c|c|}
\hline $\mathbf{C}=\mathbf{N}$ & OH & $\mathrm{NH}_{\text {valent }}$ & $\mathrm{NH}_{\text {defor }}$ & N-O & $\mathrm{C}-\mathrm{C}_{\text {arom }}$ & $\mathrm{C}-\mathrm{O}$ & $\mathrm{C}=\mathrm{S}$ & $\mathrm{C}-\mathrm{N}$ & $\mathbf{N}-\mathbf{C}$ \\
\hline \multicolumn{10}{|c|}{ Oxime 1-methylpiperidine-4-one (1) } \\
\hline 1650 & 3570 & - & - & 960 & - & - & - & - & - \\
\hline \multicolumn{10}{|c|}{ 1-methyl-4-aminopiperidine (2) } \\
\hline- & - & 3490 & 1560 & - & - & - & - & - & - \\
\hline \multicolumn{10}{|c|}{ 1-methyl-4-(2-thio-picoline-amine) piperidine (3) } \\
\hline- & - & 3410 & - & - & - & - & $\begin{array}{l}1210 \\
1530\end{array}$ & 1360 & 1500 \\
\hline
\end{tabular}




\subsection{Antibacterial activity and toxicity of preparations based on the new piperidine derivatives}

\subsubsection{Antimicrobial characteristics and toxicity of preparations ALT-6, ALT-7, ALT-S}

To determine the antibacterial capacity and toxicity of synthesized from industrial wastes 1-methyl-4- (2-thio-picoline-amine) piperidine (Alt-S), 1-(2-methylpyridin-5-yl) etil2,5-dimethylpiperidine-4-one (Alt-7) and benzoic ester oxime hydrochloride 1-methylpiperidin-4-one (Alt-6) the experimental study was conducted using established classical techniques. The research results are shown in Tables 3.3 and 3.4.

In the variant with preparations Alt-6, Alt-7, and Alt-S the vigor growth of microorganisms in a nutrient medium was not observed, that indicates to their antibacterial activity (Table 3.3).

Table 3.3

Antibacterial capacity of preparations (Experiment duration is 72 hours)

\begin{tabular}{|l|c|c|c|c|}
\hline \multicolumn{1}{|c|}{ Preparations } & Ratio & E.coli & $\begin{array}{c}\text { Salm. } \\
\text { typhimurium }\end{array}$ & $\begin{array}{c}\text { Salmonella } \\
\text { choleraesuis }\end{array}$ \\
\hline 1-methyl-4-(2-thio-picoline- & $1: 100$ & 0 & 0 & 0 \\
amine) piperidine "Alt-S" & $1: 1000$ & 1 & 1 & 0 \\
& $1: 5000$ & 1 & 1 & 1 \\
\hline Alt-6 & $1: 100$ & 0 & 0 & 0 \\
& $1: 1000$ & 1 & 1 & 0 \\
& $1: 5000$ & 1 & 1 & 1 \\
\hline AltT-7 & $1: 100$ & 0 & 0 & 0 \\
& $1: 1000$ & 1 & 0 & 1 \\
\hline Streptomycin & $1: 5000$ & 1 & 1 & 0 \\
\hline Monitoring of the microor- & & 0 & 0 & 0 \\
ganisms growth (without the & & 4 & 4 & 4 \\
preparations) & & & \\
\hline
\end{tabular}

The acute toxicity of the developed preparations was determined on white mice weighing 17-22 grams and white rats weighting 160-170 grams, they were kept in a vivarium in accordance with the norms of feeding and keeping of laboratory animals. The preparation solutions of various concentrations 
by $0,1 \mathrm{ml}$ were administered to animals orally, one time, into the stomach by a needle [101]. The control animals received a similar amount of sterile saline. The nature of the experimental animals' behavior was recorded daily.

Table 3.4

Acute toxicity of the preparations

\begin{tabular}{|c|c|c|}
\hline Preparation & $\begin{array}{c}\mathrm{LD}_{50} \text { under abdominal } \\
\text { injection to mice, } \\
\mathrm{mg} / \mathrm{kg}(\mathrm{M} \pm \mathrm{m})\end{array}$ & $\begin{array}{c}\mathrm{LD}_{50} \text { under abdominal } \\
\text { injection to rats, } \\
\mathrm{mg} / \mathrm{kg}(\mathrm{M} \pm \mathrm{m})\end{array}$ \\
\hline $\begin{array}{l}\text { 1-methyl-4-(2-thio-picoline- } \\
\text { amine) piperidine "Alt-S" }\end{array}$ & $225,3 \pm 18,62$ & $125,3 \pm 14,6$ \\
\hline 1-methyl-4-aminopiperidine & $103,20 \pm 10,16$ & $59 \pm 4,89$ \\
\hline Oxime 1-methyl-piperidine-4-one & $154 \pm 12,7$ & $77 \pm 6,01$ \\
\hline $\begin{array}{l}\text { Benzoic ester oxime hydrochloride } \\
\text { 1-methyl-piperidine-4-one (Alt-6) }\end{array}$ & $219,4 \pm 21,48$ & $119,7 \pm 11,9$ \\
\hline $\begin{array}{l}\text { 1-(2-methyl piperi-dine-5-yl) } \\
\text { ethyl-2,5-dimethylpiperidine- } \\
\text { 4-one (Alt-7) }\end{array}$ & $217,8 \pm 16,22$ & $120,4 \pm 12,3$ \\
\hline Ciprofloxacin (reference) & $176,2 \pm 9,21$ & $98,3 \pm 8,6$ \\
\hline
\end{tabular}

The results are evaluated on the basis of the index $\mathrm{LD}_{50}$, and by the changes of the clinical condition of the animals during 4 days. The Ciprofloxacin is the comparison control with the known value of the $\mathrm{LD}_{50}$ toxicity of $176,2 \pm 9,21$ and 98,3 $\pm 8,6$, respectively, for mice and rats (Table 3.4).

As evidenced by the obtained experimental data, the toxicity of all the synthetic derivatives of piperidine (Alt-6, Alt-7, Alt-S) is much lower compared with the standard - ciprofloxacin, for example, toxicity Alt-S is 1.3 times lower compared with the reference of Ciprofloxacin. The initial products used for the synthesis of 1-methyl-4- (2-thio-picoline-amine) piperidine (Alt-S) 1-methyl-4-aminopiperidine oxime and 1-methylpiperidin-4-one have more toxic properties compared with ciprofloxacin. Replacement of the oxime group at the fourth carbon atom (C4) piperidine for the amine group leads to a dramatic increase in toxicity.

Thus, benzoic ester oxime hydrochloride 1-methylpiperidin-4-one (Alt-6), 1- (2-methylpyridin-5-yl) ethyl-2,5-dimethylpiperidine-4-one (Alt-7), 1- methyl-4- (2-htio-picoline-amine) piperidine (Alt-S) can be attributed to the substances which have antibacterial activity at the dilution of 1:100 for the test strains and do not have a marked toxicity. 


\section{CHAPTER CONCLUSIONS}

1. The comparison of the experimental and literature data suggested the reaction schemes that take place in the interaction of the products of recycling of the coke production wastes and sulfur production wastes, which is the waste of the Oil Industry.

2. New methods for production of three biologically active derivatives of the piperidine with involving for the synthesis the wastes of coking and oil industry have been developed, these bioactive derivatives are as follows: the hydrochloride benzoic ester oxime 1-methylpiperidin-4-one (Alt-6), 1- (2-methyl-pyridin-5-yl) ethyl-2,5-dimethylpiperidine-4-one (Alt-7), 1-methyl-4 (2-thio-picoline-amine) piperidine (Alt-S).

3. On the basis of IR spectroscopy the presence of $\mathrm{C}=\mathrm{S}, \mathrm{C}-\mathrm{N}, \mathrm{N}-\mathrm{C}=\mathrm{S}$ and the other bonds in 1-methyl-4- (2-thio-picoline-amine) piperidine and the rest of the synthesized compounds was proved.

4. The antibacterial activity and toxicity of synthetic preparations Alt-6, Alt-7, Alt-S was evaluated. It is determined that the synthesized derivatives of piperidine Alt-6, Alt-7, Alt-S are antibacterial preparations and have no significant toxicity.

5. The bioactive properties have been determined, namely: high growthstimulating capacity of the compounds of Alt-6 Alt-7 Alt-S with respect to vegetable and grain crops. 


\section{APPLICATION OF BIOLOGICALLY PREPARATIONS ALT-6, ALT-7, ALT-S IN AGRICULTURE}

Synthesized compounds were tested in various biological activities in a number of medical and biological institutions, also they have been tested in laboratory and field conditions for 3 years. Laboratory studies conducted at the Research Institute of potatoes and vegetable farm on the northern slope of the foothill plain of Trans-Ili Alatau, also in experimental plots of "Ecology" Research Institute of the International Kazakh-Turkish University named after H.A. Yasawi.

Soil of test sites is respectively dark chestnut, medium and sierozemic.

The following vegetables were chosen as objects of study: potatoes, rare, carrots, beetroot, mustard, from cereal: wheat.

\subsection{Impact of growth stimulants ALT-6, ALT-7, ALT-S on the crop and quality of potatoes}

\subsubsection{Impact on growth and development of potato}

Being a food product potato is considered to be one of the necessary agricultural crops in all the counties, which is used as a raw material for industrial production of number of valuable products. Ethanol, produced from potato, up to date has been irreplaceable in pharmaceutical, perfume, liquor and other industries. Potato tubers contain very high quality protein, vitamins, starch and number of other substances. Potato is good cattle food, with its degree of digestibility and nutrient content it heads the list in comparison with grass and small grains.

A special attention is given to issues of increasing the productivity and improving its quality from an environmental perspective. It is evidenced by a great number of research works, aimed at improving the quality, quantity and environmental safety of this product [102-103].

For the successful development of potato farming a large-scale implementation of innovative achievements of agricultural and other sciences into production is needed. Using biologically active substances with growth stimulating, immunomodulatory and other useful properties is one of the reserves of increasing the productivity.

It is known that succinic acid ( $\mathrm{HOOC}-\mathrm{CH}_{2}-\mathrm{CH}_{2}-\mathrm{COOH}$ ) in a concentration of $0,002 \%$ is used as potato growth promoter for pre-plant treatment 
of seed grains in agricultural practices [104]. Disadvantage of succinic acid is its low growth stimulating effectiveness, yield increase does not exceed $15 \%$.

It is also known that gibberellic acid and other natural regulators are used as plant growth stimulators [105-106]. It is usually used to spray the plants in flowering time to increase potato and other crops' productivity. However in comparison with control potato productivity does not change considerably. Gibberellic acid is photochemically unstable and has a relatively low activity as succinic acid.

The most similar to our new synthesized substance Alt-6 in chemical structure, compound and exhibited activity is fospinol (or "ASA") 1, 2, 5-trymethil-4 dimetilfosfonpiperidol-4.

The structural formula of fospinol is as follows:

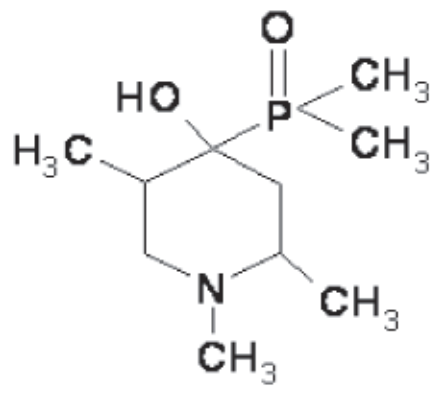

It is used as growth stimulator of green crops. However fospinol quickly loses its activity, so it cannot be considered as an effective growth stimulator. Productivity increase of potato does not exceed $11 \%$ while using fospinol [107].

While conducting research we paid a particular attention not only to productivity increase, but also to improvement in quality and increase of potato's persistency to adverse biotic and abiotic factors. These results have become a basis for identifying opportunity and feasibility of replacing familiar growth stimulators to new synthesized derivatives of piperidine.

Table 4.1 presents the research data obtained in the study of effect of agents Alt-6 Alt-7, Alt-S on evocation of potato tuber's buds.

The purpose of these experiments is to establish the optimal dosage of the agents. To do this the potato tubers were soaked in solutions of various concentrations of agents. The content of the synthesized products in solutions varied from $0,1 \%$ to $0,0001 \%$. To compare the quality of control, tubers, soaked in water and tubers, soaked in solutions of succinic acid $(0,002 \%)$ and fospinol $(0,0001 \%)$ as a model were taken. 
Usually potato's major buds of apical eyes start to grow, then lateral buds, and moreover buds of funic eyes start to grow slower and often do not sprout at all, i.e. stay in rest. This reduces the number of produced stem shoots and has an adverse effect on the potato yield.

Table 4.1

Effect of agents on evocation of potato tubers buds (laboratory experiment)

\begin{tabular}{|l|c|c|c|c|c|c|}
\hline \multirow{2}{*}{$\begin{array}{c}\text { Experiment } \\
\text { variants }\end{array}$} & \multirow{2}{*}{$\begin{array}{c}\text { Concen- } \\
\text { tration, \% }\end{array}$} & \multirow{2}{*}{ Total } & \multicolumn{3}{|c|}{ Quantity of evocated buds, qty in nos } & \multirow{2}{*}{ out of them } \\
\cline { 4 - 6 } & & & tip buds & $\begin{array}{c}\text { lateral } \\
\text { buds }\end{array}$ & $\begin{array}{c}\text { funic } \\
\text { buds }\end{array}$ & \\
\hline Control (water) & 0 & 5,0 & 3,8 & 1,2 & 0 & 100,0 \\
\hline Succinic acid & 0,002 & 5,5 & 3,9 & 1,5 & 0,1 & 110,0 \\
\hline Fospinol & 0,0001 & 5,6 & 3,8 & 1,7 & 0,1 & 116,6 \\
\hline Alt-S & 0,1 & 2,5 & 2,0 & 0,5 & 0 & 50,0 \\
\hline Alt-S & 0,01 & 4,5 & 1,7 & 2,2 & 0,6 & 90,0 \\
\hline Alt-S & 0,001 & 7,7 & 3,4 & 2,6 & 0,9 & 154,0 \\
\hline Alt-S & 0,0001 & 6,2 & 3,8 & 2,0 & 0,4 & 124,0 \\
\hline Alt-6 & 0,1 & 3,1 & 2,1 & 1,0 & 0 & 62,0 \\
\hline Alt-6 & 0,01 & 4,3 & 1,3 & 2,0 & 1,0 & 90,5 \\
\hline Alt-6 & 0,001 & 6,6 & 3,4 & 2,5 & 1,0 & 137,5 \\
\hline Alt-6 & 0,0001 & 6,3 & 3,5 & 2,0 & 0,8 & 126,0 \\
\hline Alt-7 & 0,1 & 3,2 & 2,2 & 0,8 & 0,2 & 64,0 \\
\hline Alt-7 & 0,01 & 6,0 & 3,9 & 1,9 & 0,2 & 125,0 \\
\hline Alt-7 & 0,001 & 7,0 & 3,8 & 2,2 & 1,0 & 145,8 \\
\hline Alt-7 & 0,0001 & 6,6 & 3,9 & 2,0 & 0,7 & 132,0 \\
\hline
\end{tabular}

As shown by the results of studies while treating potato tubers by Alt-S with concentration of 0,001 and $0,0001 \%$ buds sprouting increases on 54,0 and $24,0 \%$ in comparison with control. And when using Alt- 6 agent treatment of tubers with the same concentration increases buds sprouting on 37,5 and $26,0 \%$ in comparison with control. Moreover an increase of buds evocation occurs due to evocation of buds in lateral and funic parts of tubers. When treated by higher concentrations $(0,1$ and $0,01 \%)$ buds' growing is delayed on the contrary (Picture 4.1).

The optimum concentration, affecting the evocation of potato tubers' buds, is $0,001 \%$-solution of Alt- 6 and Alt-7. At concentrations higher than $0,1 \%$ inhibition of the buds sprouting process is set by 38 и $36 \%$ respectively. 


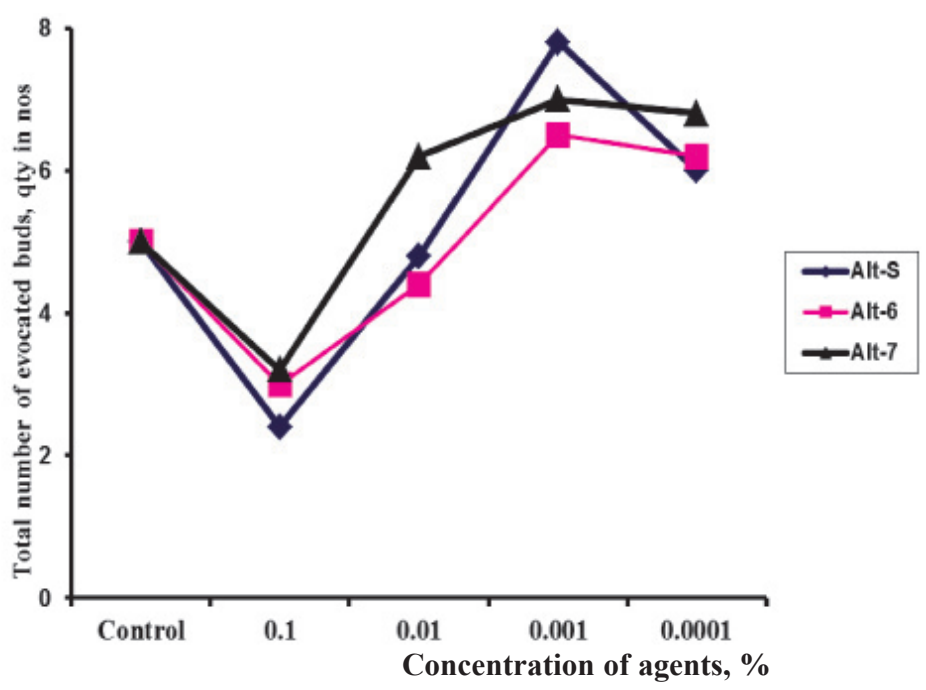

Picture 4.1. Germination energy of potato seed tubers when treated with Alt-6, Alt-7 and Alt-S solutions of various concentrations

The effect of these agents on growth, development, and productivity of potato is studied in the field conditions with use of $0,001 \%$ solutions of Alt- 6 , Alt-7 and Alt-S. The data obtained from the phenological observations of development phases and biometric measurements are presented in Table 4.2 and 4.3.

Based on observations of the development of potato it has been established that studied agents Alt-S, Alt-6, Alt-7, stimulating sprouting of tubers, accelerate the emergence of seedlings for 2 (Alt-S) and for 3 days (Alt-6, Alt-7). And the plants come into bud - formation and flowering phase 2-3 days earlier as well. (Table. 4.2). Top necrosis of potato of experiment variants started 2-3 days later, than of potato of control variants (water treatment).

When treating tubers with $0,001 \%$ - solution of studied agents while vegetation development an increase of number of stems in the bush is observed. This is explained by a large number of buds sprouting on the whole surface of tubers in eyes. (Table. 4.1).

Having analyzed the obtained from the experiment data it can be noted that the mass of the top, where the tubers were treated by agents Alt-S, Alt6 , Alt-7 at optimum concentration $(10 \mathrm{mg} / \mathrm{l})$ exceeds the mass of the top of control variant and variant with model (Picture 4.2). Thus, the development of the top in the plants, tubers of which were treated by growth 
stimulant Alt-6 made progress from 475,0-606,0 g to 610,0 g. At the control these figures amounted 382,0-475,0 $\mathrm{g}$ and $460,0 \mathrm{~g}$, at the model (fospinol $0,0001 \%)-395,0-506,0 \mathrm{~g}$ and $515,0 \mathrm{~g}$.

Table 4.2

Effect of pre-planting treatment of tubers by Alt-S, Alt-6, Alt-7 on phenological development of potato (year 2010)

\begin{tabular}{|c|c|c|c|c|c|c|}
\hline \multirow{2}{*}{$\begin{array}{l}\text { Experiment } \\
\text { variants }\end{array}$} & \multirow{2}{*}{$\begin{array}{c}\text { Date } \\
\text { of planting }\end{array}$} & \multicolumn{2}{|c|}{ Sprouting } & \multirow{2}{*}{$\begin{array}{l}\text { Bud-for- } \\
\text { mation }\end{array}$} & \multirow{2}{*}{$\begin{array}{l}\text { Flow- } \\
\text { ering }\end{array}$} & \multirow{2}{*}{$\begin{array}{c}\text { Beginning } \\
\text { of top } \\
\text { necrosis }\end{array}$} \\
\hline & & Beginning & Total & & & \\
\hline Control (water) & 28,04 & 20,05 & 22,05 & 18,06 & 25,06 & 29,08 \\
\hline Fospinol $0,0001 \%$ & 28,04 & 19,05 & 21,05 & 17,06 & 23,06 & 29,08 \\
\hline Alt-S 0,001\% & 28,04 & 18,05 & 21,05 & 16,06 & 22,06 & 01,09 \\
\hline Alt-7 0,001\% & 28,04 & 17,05 & 20,05 & 15,06 & 20,06 & 31,08 \\
\hline Alt-6 0,001\% & 28,04 & 17,05 & 20,05 & 15,06 & 20,06 & 30,08 \\
\hline
\end{tabular}

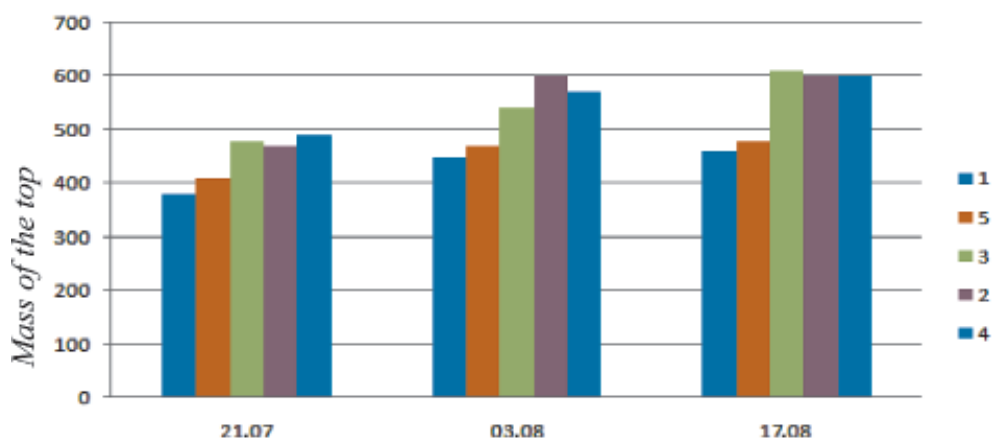

Days of taking samples

Picture 4.2. Effect of growth stimulant agents on the growth of the mass of potato tops while pre-seeding treatment of potato seed material:

1 - control (water); 2 -Alt-6; 3 -AAlt-7; 4-Alt-S; 5 -fospinol

From the analysis of the bush structure it is clear that studied agents increase the number of the stems in it. (Table 4.3) For example, when using Alt-6 the number of the stems increases compared to control by 2,2 and 2,4 pieces and compared to model to 1,9 and 2,0 pieces during sampling on $21^{\text {st }}$ of July and $3^{\text {rd }}$ of August respectively. The given pattern is also observed with respect 
to the number of leaves, i.e. pre-plant treatment of tubers by growth stimulating agents contributes to a rank growth of leaves, which play a critical part in the life of the plant.

Table 4.3

Morphological changes of potato under the influence of growth stimulators (2010 y)

\begin{tabular}{|c|c|c|c|c|c|c|}
\hline \multirow{4}{*}{$\begin{array}{c}\text { Experiment } \\
\text { variants }\end{array}$} & \multicolumn{6}{|c|}{ Dates of sampling } \\
\hline & \multicolumn{2}{|c|}{$21^{\text {st }}$ of July } & \multicolumn{2}{|c|}{$3^{\text {rd }}$ of August } & \multicolumn{2}{|c|}{$17^{\text {th }}$ of August } \\
\hline & \multicolumn{6}{|c|}{ stems / leaves per one bush } \\
\hline & pieces & G & Pieces & g & pieces & g \\
\hline \multirow[t]{2}{*}{ Control (water) } & $\underline{4,0}$ & 120,0 & $\underline{3,9}$ & 160,0 & $\underline{4,1}$ & $\underline{170,0}$ \\
\hline & 58,5 & 262,0 & 103,0 & 315,0 & 201,0 & 320,0 \\
\hline \multirow[t]{2}{*}{ Alt-6 0,001\% } & $\underline{6,2}$ & 225,0 & $\underline{6,3}$ & 176,0 & $\underline{6,1}$ & $\underline{180,0}$ \\
\hline & $\overline{100,5}$ & 252,0 & $\overline{148,0}$ & 430,0 & 276,0 & 430,0 \\
\hline \multirow{2}{*}{ Alt-7 0,001\% } & 5,0 & 212,0 & 5,1 & 186,0 & 5,2 & 190,0 \\
\hline & 97,7 & 275,0 & 149,0 & $\overline{374,0}$ & 241,0 & 440,0 \\
\hline \multirow[t]{2}{*}{ Alt-S $0,001 \%$} & 6,3 & 201,0 & $\underline{6,0}$ & 189,0 & 6,2 & 192,0 \\
\hline & 104,2 & 289,0 & 151,0 & 405,0 & 268,0 & 416,0 \\
\hline \multirow[t]{2}{*}{ Fospinol 0,0001\% } & $\underline{4,3}$ & 145,0 & $\underline{4,3}$ & 166,0 & $\underline{4,8}$ & $\underline{185,0}$ \\
\hline & 64,0 & 270,0 & 104,0 & 344,0 & 220,0 & 333,0 \\
\hline
\end{tabular}

During the whole vegetational season it was observed that the best growth and development had potato, whose seed material had been treated by new derivatives of piperidine before planting. These data confirm expressed growthstimulating activity of the agents (Alt-S, Alt-6, Alt-7) Increase in number of stems of the plant and their better growth have increased the leaf area of the bush (visual observation), i.e. under the treatment of growth-stimulators vigorous augmentation of assimilatory surface is observed. Thus, growth stimulants Alt-S, Alt-6, Alt-7 proved to be a factor, affecting the growth of assimilatory surface, and as a result improvement of productivity of potato.

Formation of the yield depends not only on assimilatory surface of the leaves but also on the number of tubers formed, that is why we conducted observation of the effect of growth stimulants Alt-S, Alt-6, Alt-7 on the tubers formation process (Table 4.4). A favorable effect of this agent on formation of tubers was established. Thus, in the first period of determining ( $21^{\text {st }}$ of July) with the control there were 7,0 tubers per 1 bush, with the variant with agent Alt-6 - 10,0, with Alt-7 - 9,7, with Alt-S - 8,8 tubers, and with the model - 
8,0 pieces. The increase in number of tubers when using growth stimulants is also established in the second and third periods of observation. Thus, the treatment of tubers by agents Alt-S, Alt-6, and Alt-7 in optimal dose stimulated the formation of potato tubers.

More intensive growth of tops of the test plants had a positive effect on the growth of the mass of tubers (Table 4.4). Thus, the increase in mass of tubers in the variant, where the tubers, for example, were treated by Alt- 6 in concentration of $0,001 \%$ went from $370,0-476,0$ to 615,0 , with the control the increase in mass of tubers went from $325,0-450,0$ to 560,0 , with fospinol - from 366,0-4260 to $600,0 \mathrm{~g}$. The increase in mass of tubers as it is seen from the results of the experiment, shown in Table 4.4, is also observed when using other growth stimulants.

An intensive growth and development of the plants and, accordingly, increase in number and mass of tubers under the influence of stimulants Alt-S, Alt-6, and Alt 7 provided additional yield compared to control and fospinol (Table 4.5).

As it is seen from the data of Table 4.5, the growth of tubers in variants with stimulators is higher than with control variants. Based on the analysis of experimental data, an increase in yield of seed and marketable fraction of potato crops can be seen when pre-plant treatment of potato seeds by Alt-6, Alt-7 and Alt-S is done. Yield of marketable potato in case of using Alt-7 in comparison with control increases by 150 times, as for yield of seed potato - by 1,25 times.

The maximum increase in the overall yield is observed when treated by Alt-7 and Alt-S. Out of all the studied agents the compound of Alt-S demonstrated its stimulating effect stronger in comparison with Alt-6 and Alt-7, model and control variant.

\subsubsection{Impact of ALT-6, ALT-7, ALT-S preparations on the potatoes quality and resistance to various diseases}

The potato scab (marsupial fungus Venturia inaegualis) is the most harmful, widespread and characteristic amongst the potato diseases. It is caused by fungi, actinomycetes luminous which are living in the soil. In the presence of the fungal disease the eyeholes of the potato tubers are affected and in the result the germination of planting material is reduced. Along with the loss of crops the market quality and taste of the products go down dramatically with the lesions scab [108]. In addition, the unfavorable changes in the climatic, environmental, technological and economic conditions of the growing significantly weaken the immune and adaptive properties of potatoes. In this connection, the special studies have been conducted on the influence of the new piperidine derivatives on the resistance to the disease and quality of potato. 


\begin{tabular}{|c|c|c|c|c|c|c|c|c|c|}
\hline \multirow{13}{*}{ 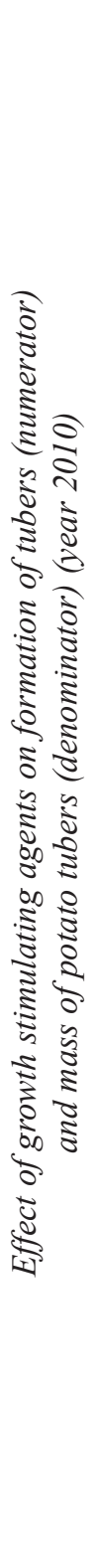 } & \multirow{4}{*}{\multicolumn{2}{|c|}{ 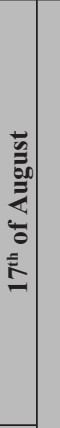 }} & \multirow{3}{*}{ 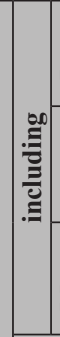 } & 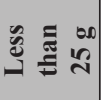 & $\frac{0}{n}$ & $\begin{array}{l}0 \\
\stackrel{0}{0} \\
\stackrel{0}{+} \\
i\end{array}$ & $\left|\begin{array}{c}0 \\
\dot{y} \\
\dot{p} \\
\dot{i} \\
i\end{array}\right|$ & \begin{tabular}{|c|}
0 \\
in \\
ñ. \\
iv
\end{tabular} & 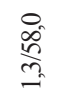 \\
\hline & & & & $\begin{array}{l}\infty \\
\infty \\
\infty \\
10\end{array}$ & $\begin{array}{l}0 \\
\tilde{n} \\
\tilde{1} \\
\tilde{n} \\
n\end{array}$ & 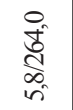 & 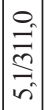 & 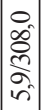 & 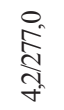 \\
\hline & & & & 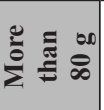 & $\begin{array}{l}\stackrel{0}{0} \\
\stackrel{0}{+} \\
\text { i }\end{array}$ & $\begin{array}{l}\text {.े } \\
\text { ते } \\
\text { - }\end{array}$ & 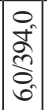 & 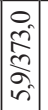 & 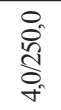 \\
\hline & & \multirow{5}{*}{ 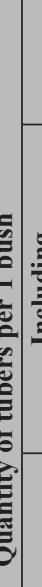 } & & ฮี & $\begin{array}{l}0 \\
\stackrel{8}{0} \\
0 \\
\infty \\
\infty\end{array}$ & 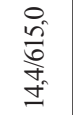 & 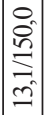 & 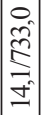 & $\begin{array}{l}0 \\
\cdots \\
\infty \\
n \\
n \\
n\end{array}$ \\
\hline & \multirow{4}{*}{ 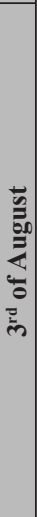 } & & & 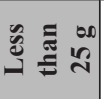 & 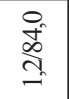 & $\begin{array}{l}0 \\
\text { ते } \\
\text { aे }\end{array}$ & \begin{tabular}{c}
0 \\
\multirow{2}{0}{} \\
0 \\
-1
\end{tabular} & $\mid \begin{array}{c}0 \\
\hat{n} \\
2 \\
0 \\
0\end{array}$ & $\begin{array}{l}0 \\
\stackrel{0}{\Delta} \\
\text { ma } \\
-1\end{array}$ \\
\hline & & & 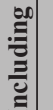 & $\begin{array}{l}\infty \\
\infty \\
\infty \\
1 \\
1\end{array}$ & $\begin{array}{l}\stackrel{0}{\vec{\theta}} \\
\frac{f}{\dot{f}}\end{array}$ & $\frac{\stackrel{0}{8}}{\stackrel{2}{+}}$ & 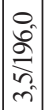 & $\mid$\begin{tabular}{l}
0 \\
\multirow{2}{c}{} \\
$\frac{1}{n}$ \\
$\forall$ \\
$\forall$
\end{tabular} & $\begin{array}{l}\frac{0}{3} \\
\frac{1}{n} \\
m\end{array}$ \\
\hline & & & & 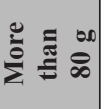 & $\begin{array}{l}0 \\
\text { ปิ } \\
\text { ô } \\
\text { i }\end{array}$ & 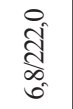 & 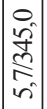 & $\begin{array}{c}n \\
2 \\
n \\
0 \\
0\end{array}$ & 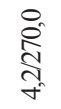 \\
\hline & & & & ฮีّ & $\begin{array}{l}\frac{0}{8} \\
\frac{1}{n} \\
\text { ñ }\end{array}$ & $\begin{array}{l}0 \\
\stackrel{0}{0} \\
\text { +o } \\
\text { di }\end{array}$ & $\left|\begin{array}{l}8 \\
8 \\
8 \\
0 \\
2 \\
0\end{array}\right|$ & $\left|\begin{array}{c}0 \\
\hat{\alpha} \\
a \\
\sigma \\
\vdots \\
=\end{array}\right|$ & $\begin{array}{l}\stackrel{\circ}{\circ} \\
\text { \&̊ } \\
\text { aू }\end{array}$ \\
\hline & \multirow{4}{*}{ 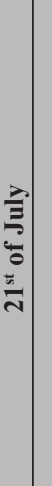 } & & & 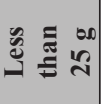 & $\begin{array}{l}\frac{0}{d} \\
\text { ì } \\
\text { di }\end{array}$ & 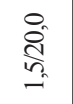 & 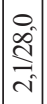 & $\left|\begin{array}{c}0 \\
\stackrel{i}{N} \\
-i \\
-1\end{array}\right|$ & $\begin{array}{l}\stackrel{0}{\pi} \\
\stackrel{m}{=}\end{array}$ \\
\hline & & & 輎 & $\begin{array}{l}\infty \\
8 \\
0 \\
11 \\
i 1\end{array}$ & 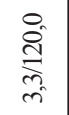 & $\begin{array}{l}\stackrel{0}{\circ} \\
\stackrel{n}{0} \\
\text { ri }\end{array}$ & 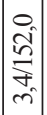 & 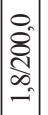 & 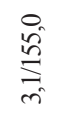 \\
\hline & & & & 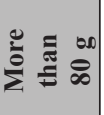 & $\frac{0}{\sqrt{n}}$ & \begin{tabular}{l}
8 \\
8 \\
\multirow{n}{n}{} \\
$n$ \\
$n$
\end{tabular} & $\left|\begin{array}{l}0 \\
\stackrel{2}{2} \\
\text { â. } \\
f\end{array}\right|$ & 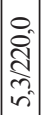 & $\begin{array}{l}\stackrel{2}{\S} \\
\stackrel{2}{n}\end{array}$ \\
\hline & & & & 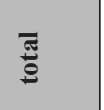 & 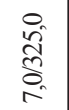 & 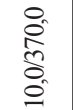 & 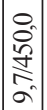 & $\left|\begin{array}{c}0 \\
\frac{0}{j} \\
\infty \\
\infty \\
\infty\end{array}\right|$ & 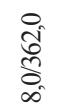 \\
\hline & \multicolumn{4}{|c|}{ 这 } & 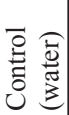 & 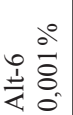 & 至 & 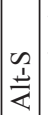 & 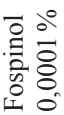 \\
\hline
\end{tabular}


Effect of pre-plant treatment of tubers

by the growth stimulants on the potato productivity

\begin{tabular}{|l|c|c|c|c|c|c|}
\hline \multirow{2}{*}{$\begin{array}{c}\text { Experiment } \\
\text { variants }\end{array}$} & \multirow{2}{*}{$\begin{array}{c}\text { Potato } \\
\text { productiv- } \\
\text { ity, tons/ha }\end{array}$} & \multicolumn{2}{|c|}{ Yield increase } & \multicolumn{3}{|c|}{$\begin{array}{c}\text { Fractional content } \\
\text { of the yield, tons/ ha }\end{array}$} \\
\cline { 5 - 8 } & tons/ha & \% & marketable & seed & $\begin{array}{c}\text { not } \\
\text { marketable }\end{array}$ \\
\hline Control (water) & 17,8 & - & - & 8,4 & 7,9 & 1,5 \\
\hline Alt-6 (0,001\%) & 21,2 & 3,4 & 16,0 & 9,5 & 10,7 & 1,0 \\
\hline Alt-7 (0,001\%) & 23,0 & 5,2 & 22,6 & 12,6 & 9,8 & 0,6 \\
\hline Alt-S (0,001\%) & 22,7 & 5,3 & 23,3 & 12,5 & 10,0 & 0,4 \\
\hline $\begin{array}{l}\text { Fosfinol } \\
(0,0001 \%)\end{array}$ & 19,8 & 2,0 & 10,1 & 9,7 & 8,9 & 1,2 \\
\hline
\end{tabular}

To determine the quality of the crops potato tubers of the new harvesting were tested for the nitrates and nitrites content by the analytical method. The extent of scab infestation was defined visually.

The results of the production tests are shown in Table 4.6. The data clearly demonstrate the positive impact of new synthesized piperidine derivatives on the quality of the crop. If in the reference test (water treatment) infection with scab was within $62 \%$, then the value of this index is reduced $\approx 2$ times when the solutions of Alt-6, Alt-7, Alt-S preparations had been used for pre-plant seeds treatment.

Table 4.6

Qualitative characteristic of the potato produced without pre-plant seeds treatment and with treatment by 0,001\% solutions of the preparations Alt-6, Alt-7, Alt-S

\begin{tabular}{|c|c|c|c|}
\hline \multirow{2}{*}{$\begin{array}{c}\text { Preparation application } \\
\text { method }\end{array}$} & \multicolumn{3}{|c|}{ Index } \\
\cline { 2 - 4 } & $\begin{array}{c}\text { Scab Infestation } \\
\text { of Tubers, \% }\end{array}$ & $\begin{array}{c}\text { Nitrite, mcg/g, } \\
\text { of wet weight }\end{array}$ & $\begin{array}{c}\text { Nitrates*, mcg/g, } \\
\text { of wet weight }\end{array}$ \\
\hline Without treatment (reference) & $62 \pm 4,0$ & $1,44 \pm 0,21$ & $11,0 \pm 0,6$ \\
\hline $\begin{array}{l}\text { Pre-plant treatment of seeds } \\
\text { by the preparations: }\end{array}$ & $20 \pm 2,0$ & $0,92 \pm 0,09$ & $4,04 \pm 0,13$ \\
Alt-6 & $27 \pm 2,1$ & $0,89 \pm 0,09$ & $5,32 \pm 0,14$ \\
Alt-7 & $22 \pm 2,0$ & $0,90 \pm 0,09$ & $5,31 \pm 0,14$ \\
\hline Alt-S & & & \\
\hline
\end{tabular}

*According to the agrochemical inspection and SES of Russia and Kazakhstan the MPC of nitrate ions for potatoes is $80 \mathrm{mg} / \mathrm{kg}$. WHO considers the permissible nitrate content in dietary foods and vegetables shall be up to $300 \mathrm{mg} \mathrm{NO} \mathrm{O}_{3}-1 \mathrm{~kg}$ of raw substance. 
Thus, pre-plant treatment of seeds by the preparations Alt-6, Alt7, Alt-S allows blocking the growth of pathogens in the early stages of the disease, providing normal physiological development of plants. The results suggest the possibility of regulation of metabolism process of the plants by the synthesized organic compounds (Alt-6, Alt-7, Alt-S). This can be used to create a highly productive farm crops with a specific change in metabolism toward the side of the greater accumulation of substances that determine the quality of the harvest.

As it is known the accumulation of nitrate and nitrite in the human body has a negative impact on human health. It was determined that vegetables are accounted for up to $90 \%$ of the daily dose of nitrates entering the human body with a balanced diet. Entry of a large quantity of nitrates with vegetables in the human body causes disorders of the gastrointestinal tract or other undesirable events. With their accumulation in the large quantities the nitrosamines are formed in the body, which have carcinogenic properties. Especially dangerous is the accumulation of nitrites as they interact with the blood oxyhemoglobin forming the insoluble methemoglobin, thus, oxygen transfer to the tissues is being sharply reduced This compound blocks the oxidation-reduction reactions in the cell, determines the state of hypoxia in the tissues, causing symptoms of poisoning. At present time doctors believe that the main cause of diseases such as stroke, heart attack, thrombosis is the formation of insoluble precipitates in the blood.

From the point of view of the nutritional value the potato quality is estimated by the content of carbohydrates, protein, vitamins, and other valuable products. Their accumulation in the first place the dry basis depends on many factors, for example, nature and climatic conditions, on the breed of the cultivated crops, the technique of cultivation and the use of fertilizers and growth stimulants.

One of the potato quality parameters other than the dry basis is vitamin "C" and starch content. As the results of experimental studies showed the significant impact of Alt-6, Alt-7, Alt-S preparations on the quality of potatoes was not established (Picture 4.3). The main components content is on the same level, i.e. the dramatic deterioration or improvement in the quality of potatoes is not observed.

Using serological assays by the drop method of Dunin-Popova [109] the experiments on the impact of the preparations Alt-6, Alt-7, Alt-S on the latent infection of potato by viruses $\mathrm{X}, \mathrm{S}, \mathrm{M}, \mathrm{Y}$ have been carried out (Tab. 4.7). 


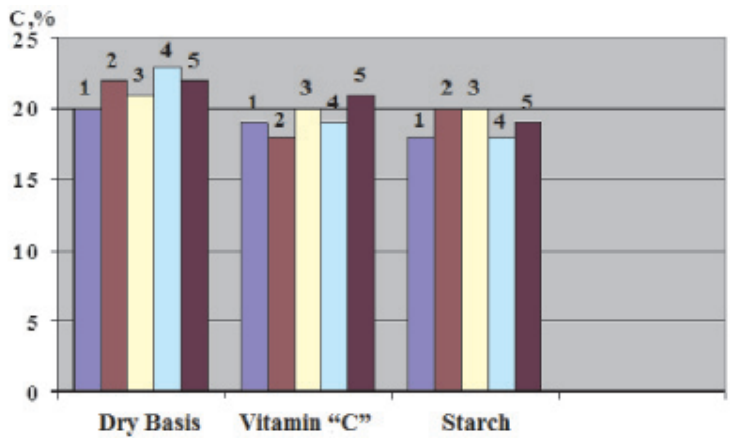

Picture 4.3. Impact of the growth stimulants on the potato quality in the case of the pre-plant treatment of the tubers:

1 -Reference; 2 -Alt-6; 3 -Alt-7; 4-Alt-S; 5 -Fospinol

Table 4.7

Data of the serological analysis on the impact of growth stimulants Alt-6 Alt-7, Alt-S on viral diseases of potatoes *

\begin{tabular}{|c|c|c|c|c|c|c|c|c|}
\hline $\begin{array}{c}\text { Variants of the } \\
\text { testing, the prepa- } \\
\text { ration content in } \\
\text { the solution, wt. } \%\end{array}$ & $\mathbf{X}$ & $\mathbf{S}$ & $\mathbf{M}$ & $\mathbf{Y}$ & $\mathbf{X}$ & $\mathbf{S}$ & $\mathbf{M}$ & $\mathbf{Y}$ \\
\cline { 2 - 9 } Reference (water) & +++ & +++ & +++ & ++- & +++ & +++ & +++ & +-+ \\
\hline $\begin{array}{c}\text { Alt-6 } \\
0,01\end{array}$ & --- & --- & --- & --- & --- & --- & --- & --- \\
0,001 & --- & --- & --- & --- & --- & --- & --- & --- \\
0,0001 & -+- & ++- & --- & --+ & --- & +-- & -++ & +-+ \\
\hline Alt-7 & & & & & & & & \\
0,01 & --- & --- & --- & --- & --- & --- & --- & --- \\
0,001 & --- & --- & --- & --- & --- & --- & --- & --- \\
0,0001 & -+- & +-- & --+ & --+ & --- & +-- & --+ & +++ \\
\hline $\begin{array}{c}\text { Alt-S } \\
0,01\end{array}$ & --- & --- & --- & --- & --- & --- & --- & --- \\
0,001 & --- & --- & --- & --- & --- & --- & --- & --- \\
0,0001 & --- & +-- & --- & --+ & --+ & +-- & -++ & --+ \\
\hline 0,01 & --- & +-- & -+- & --- & --- & +-- & --- & --- \\
0,001 & +-- & +++ & ++- & ++- & --- & ++- & ++- & ++- \\
0,0001 & ++- & +++ & +++ & +-+ & +-- & +-+ & ++- & +++ \\
\hline
\end{tabular}

*Note: $X$ - virus (PVX - regular mosaic); $S$ - virus (PVS - mottle disease of leaves); $M$-virus ( $P V M$ - involution of leaves); $Y$-virus ( $P V Y$ - banded mosaic). 
The obtained results show that in the event of soaking of the potatoes in a solution of Alt-6, Alt-7 and Alt-S preparations no plants infected with viral diseases were found. It can be concluded that the use of growth stimulant Alt-7 at concentrations of $\geq 0,001 \%$ increases the resistance of potato plants to viral diseases.

\subsection{Piperidine derivatives ALT-6, ALT-7, ALT-S as new growth stimulants and stress protectors for winter wheat}

In conditions of technogenic pollution the use of growth regulators to enhance the resistance and productivity of domestic plants is the priority direction of modern crop science.

In connection with this the actual problem is to find compounds with a broad spectrum of beneficial effects, namely, preparations combining environmental safety, low cost and relative ease of obtaining them.

We have previously demonstrated the possibility of separation from the slurry wastes that is generated in the process of the calcium carbide production, the crotonaldehyde which is the initial material for the synthesis of piperidine and a number of its derivatives [110]. On the basis of laboratory and field studies their biological activity on the growth, development and productivity of potatoes was defined.

The aim of this research was the estimation of the growth-regulating and anti-stress effect of the above preparations on the quality of seeds of the winter wheat and seedling growth under normal conditions and with a lack of moisture due to high temperatures.

Impact of Alt-6, Alt-7, Alt-S on the growth and development of winter wheat seeds was determined in comparison with reference, namely, sprouting formed during the treatment with water only. Wheat seeds steeped were watered (reference) and in water solutions of the preparations (concentration of 0,00001-0,01\%) during 20 hours.

Germination of the seeds was carried out in Petri dishes at room temperature $\left(22-24^{\circ} \mathrm{C}\right)$. The number of seeds in the sample is 50 pieces. After 4 days the swollen seeds (embryo up) were put on the wetted with distilled water strips of the filter paper, covered by other moist filter paper strips and rolled up into a roll. The lower end of the roll was immersed in distilled water in the glasses; the experiment was repeated three times.

Incubation was carried out at the room temperature for 14 days. After this time the measurement of the roots length and aerial part was carried out, the definition of the dry weight of seedlings, counting the number of germinated seeds was carried out. According to these data, the optimal concentration of growth-regulating preparations Alt-6, Alt-7 and Alt-S were determined. 
As it is well known in many countries, including the southern regions of Kazakhstan, during the growing season grain crops are subject to a number of stressful effects of the meteorological nature, related to the lack of moisture due to temperature variations in the direction of a sharp increase. In this regard, a number of the experiments have been performed to establish the availability of the stress protective properties of the preparations.

The study of the impact of Alt-6, Alt-7, Alt-S on the stability of winter wheat to dehydration has been conducted using the known methods [111] therein the conditions of water deficit are created by using 10 or $15 \%$ water solution of polyethylene glycol, the respective values of the osmotic potential equal to $-0,039$ and $-0,059 \mathrm{MPa}$, respectively (Table 4.8).

Table 4.8

\section{Impact of the Alt-7 preparation}

on the wheat germs resistance to water shortage

\begin{tabular}{|c|c|c|}
\hline \multirow{2}{*}{ Preparation concentration, \% } & \multicolumn{2}{|c|}{ Root length $\mathbf{~ m m ~ / \% ~ t o ~ r e f e r e n c e ~ a t ~ M P a ~ e q u a l ~}$} \\
\cline { 2 - 3 } & $\mathbf{- 0 , 0 5 9}$ & $\mathbf{- 0 , 0 3 9}$ \\
\hline $\begin{array}{l}\text { Reference (germs grown without } \\
\text { treatment of the preparation) }\end{array}$ & $6,0 / 73$ & $5,9 / 72$ \\
\hline 0,00001 & $6,7 / 81$ & $6,3 / 77$ \\
\hline 0,0001 & $7,2 / 87$ & $6,8 / 84$ \\
\hline 0,001 & $8,1 / 98$ & $7,7 / 95$ \\
\hline 0,01 & $8,4 / 102$ & $8,1 / 100$ \\
\hline 0,1 & $8,6 / 105$ & $8,3 / 104$ \\
\hline
\end{tabular}

The indicator of anti-stress activity of the preparations was the change of the growth rate of the length of the roots. Seedlings used as a reference were grown under conditions of water deficit without treatment by the preparations.

The results of the study of the preparations Alt-6, Alt-7 and Alt-S impact on the seedlings of winter wheat in normal and extreme conditions are given in Tables 4.9-4.11 and Picture 4.4.

Impact of Alt-6, Alt-7, Alt-S on the growth of plants depends on their concentration (see Table. 4.9). The most optimal for all the studied preparations is equal to the concentration of $0,001 \%$. In the concentration range $0,00001-0,001 \%$ the increase of the stimulating impact of the preparations on the growth processes is observed, while at higher concentrations, there is some decrease in the efficiency of their actions. 
Table 4.9

Impact of Alt-7 preparation on winter wheat germs

\begin{tabular}{|c|c|c|c|c|c|c|c|c|}
\hline \multirow[b]{2}{*}{ Variants } & \multirow{2}{*}{$\begin{array}{c}\text { Solution } \\
\text { concentra- } \\
\text { tion, } \%\end{array}$} & \multicolumn{2}{|c|}{ Root length } & \multicolumn{2}{|c|}{ Top length } & \multicolumn{2}{|c|}{$\begin{array}{l}\text { Dry weight } \\
\text { of the germ }\end{array}$} & \multirow{2}{*}{$\begin{array}{l}\text { Quantity } \\
\text { of ger- } \\
\text { minated } \\
\text { seeds, \% }\end{array}$} \\
\hline & & $\mathrm{cm}$ & $\begin{array}{c} \pm \text { to ref- } \\
\text { erence, } \\
\%\end{array}$ & $\mathrm{Cm}$ & $\begin{array}{c} \pm \text { to ref- } \\
\text { erence, } \\
\%\end{array}$ & Mg & $\begin{array}{c} \pm \text { to } \\
\text { refer- } \\
\text { ence, } \%\end{array}$ & \\
\hline $\begin{array}{l}\text { Water } \\
\text { (reference) }\end{array}$ & - & 8,2 & - & 3,0 & - & 9,9 & - & 88 \\
\hline Alt-7 & 0,00001 & 8,5 & 3 & 3,6 & 20 & 10,3 & 4 & 95 \\
\hline Alt-7 & 0,0001 & 9,1 & 11 & 3,8 & 27 & 11,5 & 16 & 96 \\
\hline Alt-7 & 0,001 & 10,2 & 24 & 4,0 & 33 & 13,4 & 35 & 98 \\
\hline Alt-7 & 0,01 & 9,9 & 20 & 3,5 & 16 & 12,9 & 30 & 92 \\
\hline Alt-7 & 0,1 & 9,0 & 9 & 2,9 & -4 & 8,7 & -13 & 91 \\
\hline
\end{tabular}

At a concentration of 0,001 and $0,01 \%$ the preparations increased seedling weight by 13,4 and 12,9\% (Alt-7), 20,9 and 11,1\% (Alt-6), 41,4 and $26,2 \%$ (Alt-S), respectively.

The results showed that the seeds treated with the preparations Alt6, Alt-7, and Alt-S, have greater vigor and seedlings, more developed root system compared to seeds (untreated) of the reference experiment. The energy of seed germination was under optimal concentration of the preparations $(0,001 \%)$ was at least $98 \%$. Under the impact of the preparations Alt-6,Alt-7 and Alt-S not only the growth of the root system is much more intensive but also aerial part of seedlings compared to the reference (Picture 4.4).

Observations in the field indicated that the seeds treated with the preparations Alt-6, Alt-7, and Alt-S, less damaged by the mold deteriorate than the untreated ones. If the number of moldy treated seeds does not exceed 3-5\%, the number of injured among the untreated seeds was 11,5-14,0\%.

Analysis of the data obtained during the field trials show an improvement in the winter wheat yields by $3-4$ centner / ha for the seeds treatment by the preparations Alt-6, Alt-7 and Alt-S compared with the reference (17 centner / ha). Under the influence of these preparations the reduction of nitrates to $3,8-5,7 \mathrm{mg} / \mathrm{kg}$ of the dry basis also occurred (Table 4.10 ).

There were no significant changes in biochemical indicators of the quality of grain observed, the protein content slightly increased $(0,6-1,3 \%)$ (Table 4.10). Of the three preparations studied the greatest impact on the overall 
protein content was provided by the preparation Alt-S. In this regard, for the study of fractional protein content in winter wheat grain the preparation Alt-S was used (Table 4.11).

\section{$\mathrm{C}, \mathrm{mg}$}

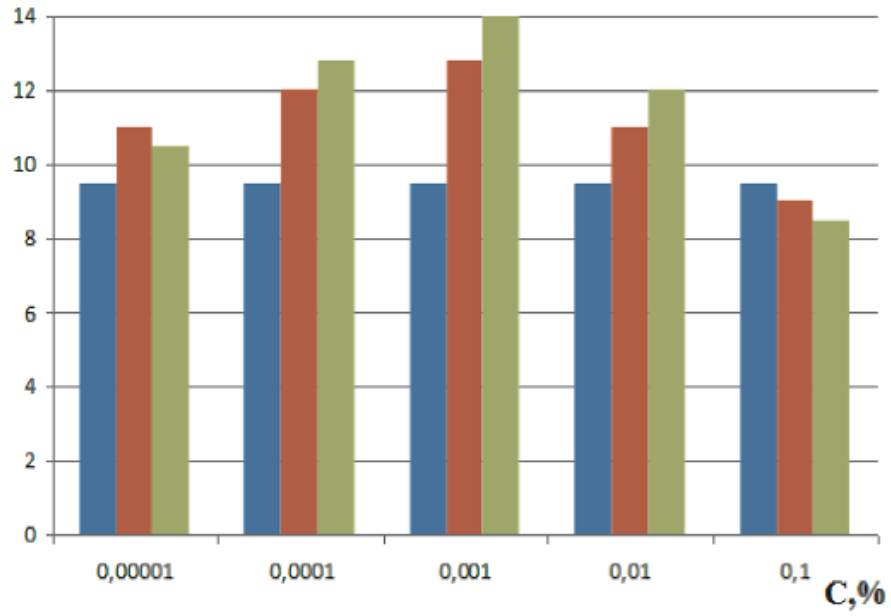

Picture 4.4. The concentrations of the dry weight of wheat germs (in mg) (Y-axis), treated with solutions of biologically active preparations

of different concentrations (in \%) (X axis):

1 -Reference (water); 2 -Alt-6; 3 -Alt-S

Table 4.10

Yield and quality of the wheat grain

\begin{tabular}{|l|c|c|c|c|}
\hline \multirow{2}{*}{\multicolumn{1}{c|}{ Indicators }} & \multirow{2}{*}{$\begin{array}{c}\text { Untreated } \\
\text { (reference) }\end{array}$} & \multicolumn{3}{c|}{ Treatment with Preparations } \\
\cline { 3 - 5 } & 17,0 & Alt-6 & Alt-7 & Alt-S \\
\hline Yields centner / ha & 20,5 & 20,0 & 21,0 \\
\hline Nitrates, mg/kg of dry basis & $55,2 \pm 1,3$ & $51,4 \pm 1,3$ & $50,6 \pm 1,2$ & $49,5 \pm 1,2$ \\
\hline Protein, \% of dry basis & $7,4 \pm 0,2$ & $8,0 \pm 0,2$ & $8,5 \pm 0,2$ & $8,7 \pm 0,3$ \\
\hline Fat, \% of dry basis & $3,9 \pm 0,1$ & $4,2 \pm 0,1$ & $4,3 \pm 0,2$ & $4,2 \pm 0,2$ \\
\hline Fiber, \% of dry basis & $2,4 \pm 0,2$ & $2,5 \pm 0,2$ & $2,5 \pm 0,2$ & $2,5 \pm 0,2$ \\
\hline Starch, \% of dry basis & $65,0 \pm 1,8$ & $65,1 \pm 1,8$ & $65,0 \pm 1,8$ & $65,2 \pm 1,8$ \\
\hline Ash, \% of dry basis & $1,3 \pm 0,05$ & $1,4 \pm 0,05$ & $1,4 \pm 0,05$ & $1,4 \pm 0,05$ \\
\hline
\end{tabular}


Impact of the pre-plant treatment by 0,001\% solution of Alt-S preparation on the quality of the winter wheat grain

\begin{tabular}{|c|c|c|c|c|c|c|c|}
\hline \multirow{2}{*}{ Variant } & \multirow{2}{*}{$\begin{array}{l}\text { Total } \\
\text { Pro- } \\
\text { tein }\end{array}$} & \multicolumn{4}{|c|}{$\begin{array}{l}\text { Protein content in fractions, \% of total } \\
\text { quantity of the protein in the grain }\end{array}$} & \multicolumn{2}{|c|}{ Fibrin \% } \\
\hline & & $\begin{array}{l}\text { albu- } \\
\text { mins }\end{array}$ & Globulins & $\begin{array}{l}\text { prola } \\
\text { mins }\end{array}$ & $\begin{array}{l}\text { gluta } \\
\text { mine }\end{array}$ & wet & dry \\
\hline $\begin{array}{l}\text { Refer- } \\
\text { ence }\end{array}$ & $7,4 \pm 0,2$ & $1,90 \pm 0,04$ & $0,31 \pm 0,009$ & $2,52 \pm 0,08$ & $2,67 \pm 0,08$ & $31,1 \pm 1,2$ & $10,5 \pm 0,4$ \\
\hline $\begin{array}{l}\text { Treat- } \\
\text { ment by } \\
\text { prepara- } \\
\text { tion }\end{array}$ & $8,7 \pm 0,2$ & $2,32 \pm 0,09$ & $0,42 \pm 0,01$ & $2,56 \pm 0,07$ & $3,40 \pm 0,14$ & $32,8 \pm 1,3$ & $11,0 \pm 0,4$ \\
\hline
\end{tabular}

The results of the biochemical analysis of protein fractions and fibrin content in grain (Table 4.11) suggest that an increase in protein content under treatment by the growth stimulating preparations is mainly associated with an increase in the content of globulins and glutamine. The content of the fibrin in the grain in the above variants of treatment with Alt-S is higher in comparison with the reference. Based on these data, we can talk about improving the baking qualities of flour derived from these grains.

Thus, as a result of laboratory tests the stimulating impact of the new preparations Alt-6, Alt-7, Alt-S on the growth of the winter wheat was determined and also the range of effective preparations concentration of $(0,01-$ $0,001 \%$ ) was identified, providing a significant increase in the length of the roots and aerial growth of the dry weight of the seedlings. It should be noted the stress protective effect of these preparations on winter wheat.

Based on the experimental data, the preparations Alt-6, Alt-7 and Alt-S can be recommended as growth regulators and stress protectors for winter wheat cultivation in the areas of risk farming.

\subsection{Impact of ALT-6, ALT-7, ALT-S preparations on growth and development of radish}

Analysis of published data [63, 70, 105-106, 112-116] and the results of our studies [21, 117-119] suggest that modern technologies of growing vegetable crops require the use of more efficient, multifunctional regulators of growth of a new generation, allowing optimizing the plant nutrition, stimulate the growth and development of plants, induce the resistance of the crops to 
unfavorable factors, increase productivity and improve the biochemical composition of the harvest, without damage to agro-ecology and quality of received products.

In connection with the environmental requirements as the growth regulator is concerned the priority shall be given low consumption substances and their mixtures. They not only improve plant growth and development, but also have a significant impact on migration and translocation of dangerous toxins heavy metals, radio nuclides, nitrates and others in the soil-plant system and their redistribution of the plants body [120]. Moreover, each of the known preparations is designed to stimulate growth and development, and increase yields of certain crops in certain doses, timing and method of application. Violation of these requirements may reduce the desired effect. In this regard, we have conducted laboratory, vegetation, field studies with synthesized derivatives of piperidine Alt-6, Alt-7 and Alt-S to determine their impact on the growth and development of radish and other crops.

In our prior laboratory, vegetation, field studies we showed the beneficial effects of new preparations Alt-6, Alt-7 and Alt-S on the growth and development of potatoes, carrots, beets and other crops. To expand the possibilities of their use it was necessary to conduct research with radish, which has not only nutritious, but also curative properties due to the content of vitamins, hormones, enzymes, and a number of useful mineral and spicy substances.

Radish was grown in natural conditions in boxes without a bottom with the size $50 \times 100 \times 50$ at the pilot plot of the A. Yasavi SRI "Ecology" MKTU. using gray soils. Before sowing, the required amounts of nutrients were put into the soil ( $\mathrm{N}: \mathrm{P}: \mathrm{K}=1,0: 0,5: 1,5$ at a dose of nitrogen $60 \mathrm{~kg} / \mathrm{ha}$ in the form of ammonium nitrate, potassium phosphate monobasic [121], as well as arsenic in the form of sodium arsenite and cadmium nitrate. The humus content was $1,95-2,4 \%$. The seeds were sown in the amount of 50 pieces/box. Radish was grown to full maturity. Tests were repeated six times.

The new synthesized compound Alt-7 (1-2-methylpyridin-5-yl) ethyl-2,5dimetilpiperidine-4-one) was applied as regulator. Previously, we studied its effect on the buds revival of the potato tubers and determined the activity and the optimal dose of $0,001 \%$. It is shown that Alt-7, activating the germination of seeds, helps to ensure a high-quality root system [122].

Influence of Alt-6, Alt-7 and Alt-S preparations on the growth and development of radish was studied in three different ways of the treatment and also only pre-plant treatment of seeds with presence of arsenic and cadmium and without these metals. 
Tables 4.12-4.15 shows the results of experiments on the study of the impact of the growth stimulating preparations on the biometrics parameters of the radish root during the molting phase and in the phase of the industrial ripeness of the root crops, on the yield and quality of the products obtained,

Table 4.12

Influence of different ways of applying of 0,001\% solution of the preparations of Alt-6, Alt-7 and Alt-S on biometrics of the radish during root molting phase (beginning of the formation of roots)

\begin{tabular}{|c|c|c|c|c|c|}
\hline \multirow[b]{2}{*}{$\begin{array}{l}\text { Method of application and } \\
\text { the name of the preparation }\end{array}$} & \multirow{2}{*}{$\begin{array}{c}\text { Number } \\
\text { of leaves, } \\
\text { pieces } / \% \\
\text { of reference }\end{array}$} & \multicolumn{2}{|c|}{ Rosette of leaves } & \multicolumn{2}{|c|}{ The biggest leaf } \\
\hline & & $\begin{array}{l}\text { height, } \\
\mathrm{cm}\end{array}$ & $\begin{array}{l}\text { diameter, } \\
\mathrm{cm}\end{array}$ & $\begin{array}{l}\text { length, } \\
\mathrm{cm}\end{array}$ & $\begin{array}{c}\text { diameter, } \\
\mathrm{cm}\end{array}$ \\
\hline Without treatment (reference) & $6,2 / 100$ & 19,0 & 37,3 & 22,0 & 8,4 \\
\hline $\begin{array}{c}\text { Preplant seeds treatment } \\
\text { Alt-6 } \\
\text { Alt-7 } \\
\text { Alt-S }\end{array}$ & $\begin{array}{l}7,5 / 20,9 \\
8,0 / 29,0 \\
8,9 / 43,5\end{array}$ & $\begin{array}{l}21,0 \\
22,0 \\
22,0\end{array}$ & $\begin{array}{l}40,5 \\
42,7 \\
43,0\end{array}$ & $\begin{array}{l}24,4 \\
25,3 \\
25,8 \\
\end{array}$ & $\begin{array}{c}9,1 \\
10,0 \\
10,5\end{array}$ \\
\hline $\begin{array}{l}\text { Spraying during the root } \\
\text { molting phase } \\
\text { Alt-6 } \\
\text { Alt-7 } \\
\text { Alt-S }\end{array}$ & $\begin{array}{c}8,6 / 38,7 \\
10,1 / 62,9 \\
10,0 / 61,3\end{array}$ & $\begin{array}{l}23,0 \\
24,0 \\
24,0\end{array}$ & $\begin{array}{l}45,0 \\
46,3 \\
46,5\end{array}$ & $\begin{array}{l}25,5 \\
27,0 \\
27,7\end{array}$ & $\begin{array}{l}10,4 \\
11,7 \\
12,2\end{array}$ \\
\hline $\begin{array}{c}\text { Complex treatment } \\
\text { Alt-6 } \\
\text { Alt-7 } \\
\text { Alt-S }\end{array}$ & $\begin{array}{c}8,0 / 29,0 \\
11,3 / 82,1 \\
10,7 / 72,6\end{array}$ & $\begin{array}{l}22,0 \\
25,0 \\
25,0\end{array}$ & $\begin{array}{l}43,1 \\
43,8 \\
43,2\end{array}$ & $\begin{array}{l}26,0 \\
27,8 \\
27,4\end{array}$ & $\begin{array}{l}11,0 \\
12,0 \\
11,7\end{array}$ \\
\hline
\end{tabular}

In all treatment methods the positive effect of the studied bio-stimulants on the plant foliage of the radish was noted. It was determined that at the increase of the number of leaves, the greatest effect is observed at the complex treatment, i.e. during pre-plant seeds soaking (for 1 day) and spraying of vegetating plants in the phase of root molting i.e. the phase of early formation of the root (Table 4.12).

The positive effect of the complex treatment is characteristic of two preparations Alt-7 and Alt-S, the number of leaves is increased by 82,1 and $72,6 \%$, respectively, compared to the reference experiment. Best results are obtained by the preplant seed treatment by the preparation Alt-S, the amount of generated leaves above $43,5 \%$ as compared with the reference. When spraying 
during the phase of the root molting the actions of Alt-7 and Alt-S preparations are close, the number of leaves is increased by 62,9 and $61,3 \%$ compared with the reference.

All the applied types of the treatment with use of Alt-6, Alt-7 and Alt-S modify biometrics parameters of the radish both during the root molting phase and during the phase of the industrial ripeness of the root crop.

The following was revealed: the increase in height of the rosette of leaves, number of leaves per plant and the size of the leaf plates, i.e., increasing the surface area of assimilation (Table 4.12 and 4.13).

Table 4.13

Biometrics parameters of the top parts of the radish during the phase of the industrial ripeness of root crops under different methods of the treatment by the preparations Alt-6, Alt-7, Alt-S

\begin{tabular}{|l|c|c|c|c|}
\hline \multirow{2}{*}{ Biometrics parameters } & \multicolumn{3}{|c|}{ Method of the application of the preparations } \\
\cline { 2 - 5 } & $\begin{array}{c}\text { Treatment } \\
\text { by Water } \\
\text { (reference) }\end{array}$ & $\begin{array}{c}\text { Preplant } \\
\text { treatment } \\
\text { of seeds }\end{array}$ & $\begin{array}{c}\text { Spraying } \\
\text { during root } \\
\text { molting } \\
\text { phase }\end{array}$ & Complex \\
\hline \multicolumn{4}{|c|}{ Alt-6 } \\
\hline Total number of leaves, pcs & 18,3 & 22,0 & 21,4 & 21,6 \\
\hline $\begin{array}{l}\text { Dimension of the biggest leaf, } \\
\text { cm length/diameter }\end{array}$ & $30,3 / 12,1$ & $32,1 / 14,7$ & $31,7 / 14,0$ & $33,6 / 15,1$ \\
\hline \multicolumn{5}{|c|}{ Alt-7 } \\
\hline Total number of leaves, pcs & 19,1 & 22,5 & 22,0 & 23,4 \\
\hline $\begin{array}{l}\text { Dimension of the biggest leaf, } \\
\text { cm length/diameter }\end{array}$ & $29,9 / 13,2$ & $33,0 / 15,1$ & $33,1 / 14,9$ & $37,1 / 16,8$ \\
\hline \multicolumn{5}{|c|}{ Alt-S } \\
\hline Total number of leaves, pcs & 19,5 & 23,4 & 23,5 & 27,2 \\
\hline $\begin{array}{l}\text { Dimension of the biggest leaf, } \\
\text { cm length/diameter }\end{array}$ & $28,6 / 13,0$ & $37,8 / 18,0$ & $35,4 / 16,9$ & $40,2 / 19,9$ \\
\hline
\end{tabular}

The application of Alt-6, Alt-7 and Alt-S also contributed to the increase in plant productivity and improve the structure of the crop (Table 4.14). The weight of the root crop increased under preplant treatment by Alt-6, Alt-7 and Alt-S, on average 1,2 times, under the spray before the formation of root crops with Alt-6, Alt-7 1,1 and Alt-S 1,2 fold and during the complex treatment 1,2 times compared with the reference. 
Table 4.14

The dependence of yield and root structure of the radish plants on the method of the treatment by the growth stimulants Alt-6, Alt-7 and Alt-S

\begin{tabular}{|c|c|c|c|}
\hline Method of treatment & $\begin{array}{c}\text { Length/diameter } \\
\text { of the root crop, } \\
\text { Cm }\end{array}$ & $\begin{array}{c}\text { Weight } \\
\text { of Root } \\
\text { crop, } \mathbf{g}\end{array}$ & $\begin{array}{c}\text { Yield per } \\
\text { Unit, } \\
\mathbf{k g} / \mathbf{m}^{\mathbf{2}}\end{array}$ \\
\hline Treatment by water (reference) & $14,2 / 5,3$ & 290 & 3,8 \\
\hline Preplant seeds treatment & & & \\
Alt-6 & $19,1 / 6,2$ & 349 & 4,5 \\
Alt-7 & $18,7 / 6,5$ & 358 & 5,7 \\
Alt-S & $20,2 / 6,1$ & 360 & 4,7 \\
\hline Apraying before early formation of the root & & & \\
Alt-6 & $15,5 / 5,0$ & 336 & 4,4 \\
Alt-7 & $16,6 / 5,3$ & 342 & 4,9 \\
Alt-S & $17,5 / 6,0$ & 350 & 4,5 \\
\hline Alt-6 & & & \\
Alt-7 & $18,4 / 5,5$ & 351 & 4,6 \\
Alt-S & $18,0 / 5,7$ & 348 & 4,5 \\
& $19,3 / 6,1$ & 357 & 5,7 \\
\hline
\end{tabular}

The data of the biochemical analysis (Table 4.15) show the slight change in the weight of the dry basis, the increase in the level of accumulation of $\beta$-carotene and ascorbic acid was defined at preplant seed treatment by the preparations Alt- 6 by 35 and $3 \%$, Alt- 7 by 47 and $4 \%$, Alt-S by 50 and $2 \%$, respectively, compared with the reference.

While spraying in the root seedbeds and the complex treatment by the preparations (Alt-6, Alt-7, Alt-S), on the contrary, a decrease in the ascorbic acid content in the root crops and $\beta$-carotene content in the root crops is higher compared to the reference experiment. For example, $\beta$-carotene content increases by spraying Alt- 6 by $60 \%$, Alt- $7-54 \%$, Alt-S $-66 \%$, with the complex treatment Alt- 6 by $11 \%$, Alt- $7-16 \%$, Alt-S $-9 \%$ in comparison with the data obtained from the experiments where no treatments were carried out.

Thus, it is shown that the effectiveness of piperidine derivatives on the growth, development and productivity and quality parameters of the radish plants was dependent on the method of use of the preparations Alt-6, Alt-7, Alt-S. 
Table 4.15

Quality parameters of radish plants grown at different methods of treatment by the growth stimulating preparations

\begin{tabular}{|c|c|c|c|}
\hline \multirow{2}{*}{ Metod of Treatment } & \multicolumn{3}{|c|}{ Content in the root crop } \\
\cline { 2 - 4 } & Dry basis, \% & $\boldsymbol{\beta}$-caratene, mg & Ascorbic acid, mg \\
\hline Treatment by water (reference) & $10,1 \pm 0,2$ & $9,0 \pm 0,1$ & $50,4 \pm 0,4$ \\
\hline Preplant seeds treatment & & & \\
Alt-6 & $10,9 \pm 0,2$ & $12,3 \pm 0,2$ & $52,2 \pm 0,5$ \\
Alt-7 & $10,0 \pm 0,2$ & $13,2 \pm 0,2$ & $52,4 \pm 0,5$ \\
Alt-S & $10,2 \pm 0,2$ & $13,5 \pm 0,2$ & $51,8 \pm 0,5$ \\
\hline Spraying before early forma- & & & \\
tion of the root & $10,1 \pm 0,2$ & $14,4 \pm 0,2$ & $49,6 \pm 0,4$ \\
Alt-6 & $10,9 \pm 0,2$ & $13,9 \pm 0,2$ & $50,0 \pm 0,4$ \\
Alt-7 & $10,4 \pm 0,2$ & $15,0 \pm 0,2$ & $50,1 \pm 0,4$ \\
Alt-S & & & \\
Alt-6 & $10,8 \pm 0,2$ & $10,0 \pm 0,1$ & $46,8 \pm 0,3$ \\
Alt-7 & $10,9 \pm 0,2$ & $10,6 \pm 0,1$ & $46,9 \pm 0,3$ \\
Alt-S & $10,0 \pm 0,2$ & $9,8 \pm 0,1$ & $50,0 \pm 0,4$ \\
\hline \multicolumn{2}{|c}{} \\
\hline
\end{tabular}

The positive impact of these three preparations on the yield of the radish has been determined. The impact of the action took the form of the increase in the root crops weight, stimulating leaves forming process and increase of the assimilation surface of the leaves of plants. These preparations also have an effect on the quality of the radish. The dry basis, $\beta$ - carotene, ascorbic acid content has increased.

\subsection{Impact of ALT-6, ALT-7, ALT-S preparations on growth and development of beetroot and carrot}

One of the crops that along with potatoes occupy a special place in human nutrition is sugar beet and carrot. Sugar beet is the basis of sugar bearing crops in Kazakhstan, therefore, it is essential to increase in its collection both per area unit and receive products with high sugar content in any stressful situations. Due to climatic and meteorological characteristics of the south of Kazakhstan in the mid-term of the vegetation the sugar beet undergoes a number of stress factors, for example, especially in July and August the lack of moisture and high temperature are felt which are limiting factors that determine productivity. One of the ways to improve the productivity of sugar beet is the use of the stress protectors and regulators of plants growth and development. 
As the results of our research showed with potatoes and other crops the synthesized by us piperidine derivatives reparations Alt-6, Alt-7, Alt-S are promising stress protectors and phytoregulators of the new generation.

The study tof he effects of the above preparations on the mass consumption crops the sugar beets and carrots presented a high scientific and practical interest. Due to the fact that stimulants have a significant impact on the growth and development of plants in the initial phase, in the case of beet and carrot we also performed preplant seed treatment.

As it is known, a huge role for the further development of any biota representative is played by the profound changes taking place in the seed embryo, which ultimately leads to a change in the flow of biological processes at the cellular level. At the same time this enhances the activity of the enzymes, accelerates the process of photosynthesis, increasing the carbohydrate content of the leaves and activating the ability of producing.

The acceleration of the seeds germination allows to some extent to avoid the inhibitory effect of weeds.

On the basis of experimental studies the possibilities of changing the productivity by the growth stimulating substances [123] have been shown. Changing of the growth processes depends on the concentration of the used preparations, if the acceleration of the growth processes occurs at low concentrations, at the high on the contrary, inhibition is taking place, i.e. inhibition of growth. Therefore, it is necessary for each crop to establish by tests the optimum concentration range of the preparation used for growth regulation.

Table 4.16, respectively, shows the experimental data obtained in research on the effect of different concentrations of preparations Alt-6, Alt-7 and Alt-S on the vigor and seed germination of carrots and beets in the preplant seeds treatment.

Maximum seed vigor of both the carrots and beets is observed in the range of the preparation concentrations from $0,001-0,0001 \%$. When the preparation concentrations equals to $0,01 \%$ the germination of seeds of the test plants becomes comparable to the reference, and above this concentration the inhibition of growth processes is defined.

The conducted phenological studies have shown that preparations Alt-6, Alt-7, Alt-S during the seeds and plants treatment accelerate by 3-4 days the appearance of early and level sprouts, by 3-4 days the formation of leaves, by 5,6 days the formation of roots, by $8-10$ days and nights the coming of the industrial ripeness of the root crops. The earliest onset of phenophases Alt-6, Alt-7 and Alt-S in beets and carrots was noted in the variant with complex 
treatment of the plants that is to say, at the combination of preplant treatment of seeds and in the phase of the formation of roots. A preplant seed's soaking in the solutions of Alt- 6 , Alt-7 and Alt-S preparations during 2 days increases the growth vigor. The optimum concentration of the preparations that affect the germination and sprouting of seeds both beet and carrot is the concentration equal to $10^{-3} \%$. With this optimum concentration of the preparations the plant density in the range of 360-370 thousand pieces of beet / ha and 10251030 thousands of pieces of carrot / ha is provided.

Table 4.16

The results of experiments preplant treatment of seeds of the carrots and beets by the solutions of Alt-6, Alt-7, Alt-S (numerator is vigor\% and the denominator is germination\%)

\begin{tabular}{|c|c|c|c|c|c|}
\hline \multirow{2}{*}{ Name of the preparations } & \multicolumn{5}{|c|}{ Preparation concentration, \% } \\
\cline { 2 - 6 } & $\mathbf{1 0}$ & $\mathbf{1 0}^{-\mathbf{3}}$ & $\mathbf{1 0}^{-\mathbf{2}}$ & $\mathbf{1 0}^{-\mathbf{1}}$ & $\mathbf{0}$ \\
\hline \multicolumn{7}{|c|}{ Carrots } \\
\hline Alt-6 & $63 / 92$ & $60 / 100$ & $55 / 98$ & $47 / 83$ & $44 / 70$ \\
\hline Alt-7 & $59 / 88$ & $64 / 99$ & $58 / 94$ & $24 / 66$ & $43 / 68$ \\
\hline Alt-S & $55 / 91$ & $62 / 100$ & $50 / 89$ & $34 / 77$ & $42 / 71$ \\
\hline \multicolumn{7}{|c|}{ Beets } \\
\hline Alt-6 & $67 / 89$ & $74 / 99$ & $58 / 90$ & $30 / 46$ & $62 / 72$ \\
\hline Alt-7 & $59 / 91$ & $70 / 100$ & $60 / 95$ & $23 / 37$ & $62 / 72$ \\
\hline Alt-S & $63 / 92$ & $73 / 100$ & $67 / 83$ & $35 / 60$ & $63 / 70$ \\
\hline
\end{tabular}

On the basis of biochemical analysis the chlorophyll content in the sugar beet and carrot was determined. It is known that chlorophyll plays an important role in the photosynthesis. Therefore, we studied the influence of preparations Alt-6, Alt-7, Alt-S on the content of chlorophyll in the leaves of carrots and sugar beets. The results are shown in Tables 4.17-4.18.

Under the impact of the piperidine derivatives that have a biogenic property the dry basis content during the complex treatment in beet leaves made 13,3\% (Alt-6), 13,0\% (Alt-7), 12,9\% (Alt-S), sugars, respectively, 2,8; 2,7 and $2,9 \%$ and chlorophyll 34,$3 ; 33,9$ and $33,7 \%$. We also observed increase in carrot dry basis content, sugars and chlorophyll during the complex treatment of the plants. 
Content of the dry basis, sugar, chlorophyll (\%)

Table 4.17 in leaves of the beet at the phase of the roots formation

\begin{tabular}{|c|l|l|l|}
\hline Methods of treatment by the preparation & Dry basis & Sugar & Chlorophyll \\
\hline Treatment by water (reference) & $12,0 \pm 0,1$ & $2,2 \pm 0,05$ & $25,9 \pm 0,2$ \\
\hline Preplant treatment of seeds & & & \\
Alt-6 & $12,6 \pm 0,1$ & $2,5 \pm 0,05$ & $32,0 \pm 0,2$ \\
Alt-7 & $12,6 \pm 0,1$ & $2,5 \pm 0,05$ & $32,8 \pm 0,2$ \\
Alt-S & $12,7 \pm 0,1$ & $2,6 \pm 0,05$ & $33,0 \pm 0,2$ \\
\hline Treatment only at the phase & & & \\
of the root formation & & & \\
Alt-6 & $12,1 \pm 0,1$ & $2,7 \pm 0,05$ & $29,8 \pm 0,2$ \\
Alt-7 & $12,2 \pm 0,1$ & $2,6 \pm 0,05$ & $30,0 \pm 0,2$ \\
Alt-S & $12,0 \pm 0,1$ & $2,7 \pm 0,05$ & $30,7 \pm 0,2$ \\
\hline Complex treatment & & & \\
Alt-6 & & & \\
Alt-7 & $13,3 \pm 0,1$ & $2,8 \pm 0,05$ & $34,3 \pm 0,2$ \\
Alt-S & $13,0 \pm 0,1$ & $2,7 \pm 0,05$ & $33,9 \pm 0,2$ \\
\multicolumn{2}{|c|}{} \\
\hline \multicolumn{2}{|c|}{} & & \\
\hline
\end{tabular}

Table 4.18

Content of the dry basis, sugar, chlorophyll (\%) in leaves of the carrot at the phase of the roots formation

\begin{tabular}{|c|c|l|c|}
\hline Methods of treatment by the preparation & Dry basis & Sugar & Chlorophyll \\
\hline Treatment by water (reference) & $9,4 \pm 0,1$ & $3,5 \pm 0,05$ & $21,9 \pm 0,2$ \\
\hline Preplant treatment of seeds & & & \\
Alt-6 & $9,7 \pm 0,1$ & $3,7 \pm 0,05$ & $22,8 \pm 0,2$ \\
Alt-7 & $9,6 \pm 0,1$ & $3,8 \pm 0,05$ & $23,6 \pm 0,2$ \\
Alt-S & $9,9 \pm 0,1$ & $3,7 \pm 0,05$ & $23,7 \pm 0,2$ \\
\hline Treatment only at the phase & & & \\
of the root formation & & & \\
Alt-6 & $9,9 \pm 0,1$ & $3,6 \pm 0,05$ & $22,0 \pm 0,2$ \\
Alt-7 & $10,2 \pm 0,1$ & $3,6 \pm 0,05$ & $22,6 \pm 0,2$ \\
Alt-S & $10,1 \pm 0,1$ & $3,7 \pm 0,05$ & $22,9 \pm 0,2$ \\
\hline Complex treatment & & & \\
(preplant and during root formation) & & & \\
Alt-6 & $10,4 \pm 0,1$ & $4,0 \pm 0,05$ & $23,1 \pm 0,2$ \\
Alt-7 & $10,6 \pm 0,1$ & $3,9 \pm 0,05$ & $23,9 \pm 0,2$ \\
Alt-S & $10,5 \pm 0,1$ & $3,9 \pm 0,05$ & $24,0 \pm 0,2$ \\
\hline \multicolumn{2}{|c|}{} \\
\hline
\end{tabular}


Due to the fact that morphophysiological feature that significantly affect the accumulation of sugar is, a number of conducting bundles in the petioles of sugar beet leaves the dependence of the index on the influence of biologically active compounds (BAP) was studied. The increase of the number of conducting bundles in the leaf cuttings in the presence of BAP as compared to the reference (Table 4.19) was determined. With the complex treatment of the crops by the biologically active preparations Alt-6, Alt-7 and Alt-S the difference with the reference makes, respectively, 1,9;2,0; 5,5 pieces. The largest number of conducting bundles observed during the treatment by the sulfur containing preparation Alt-S indicates the increase in the volume of the transported substances, that is to say, it contributes to a more intensive growth and development of plants.

Table 4.19

Impact of BAP on the number of conducting bundles in the petioles of the sugar beet during the complex treatment

\begin{tabular}{|c|c|c|}
\hline Variants & $\begin{array}{c}\text { Number of the con- } \\
\text { ducting bundles, pes }\end{array}$ & $\begin{array}{c}\text { Number } \pm \text { to reference, } \\
\text { pes }\end{array}$ \\
\hline Reference (no treatment) & 21,4 & - \\
\hline Treatment with the preparations: & & 1,9 \\
Alt-6 & 23,3 & 2,0 \\
Alt-7 & 23,4 & 5,5 \\
Alt-S & 26,9 & \\
\hline
\end{tabular}

While soaking the seeds in the solutions of the growth regulators at the optimal growth stimulating concentrations $(0,001 \%)$ the active growth of the roots and tops of the seedlings of carrots and beets was noted in comparison to the reference. Preplant treatment of the seeds by our synthesized derivatives of the piperidine had a significant impact on the morphology of the beet and carrot plants. The changes in the dynamics of the assimilation surface of the leaves upwards are clearly seen on Pictures 4.5 and 4.6.

Plants grown from the seeds treated with preparations Alt-6, Alt-7, Alt-S, better grow and develop, earlier entering into the phase of roots molting, earlier coming into the bundle and economic ripeness. These plants have the larger frondescence that can be seen from the results of the dynamics of growth of assimilation surface of the leaves of carrots and beets (Pictures 4.5 and 4.6). 


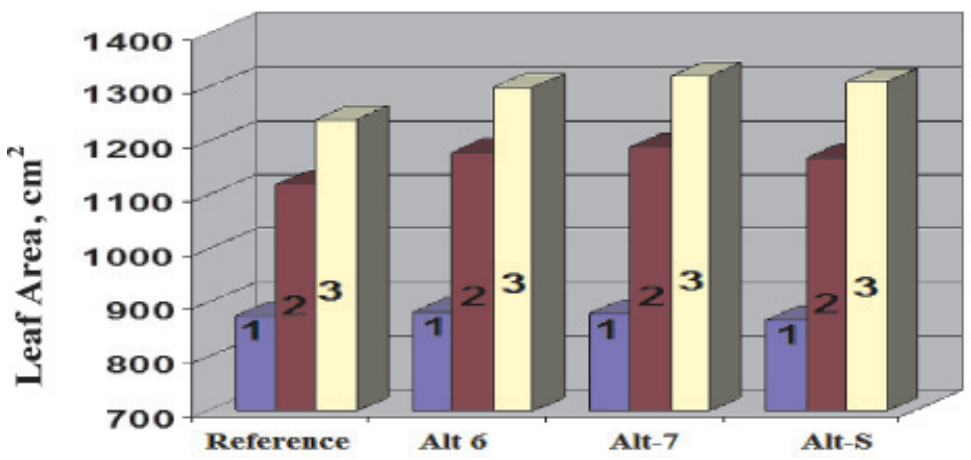

Picture 4.5. Influence of the preparations on the dynamics of growth of the assimilation surface of the beet leaves: $1-10^{\text {th }}$ of July; $2-10^{\text {th }}$ of August; $3-10^{\text {th }}$ of September

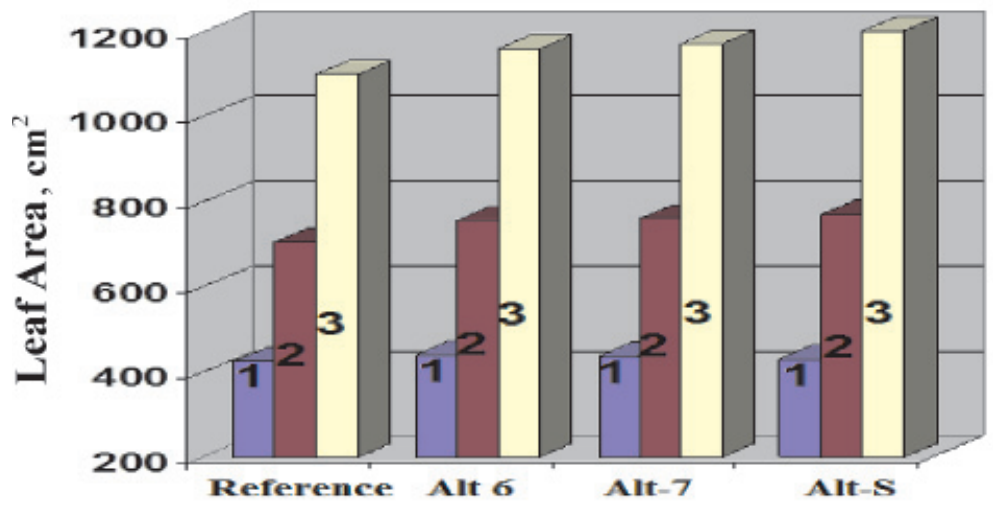

Picture 4.6. Influence of the preparations on the dynamics of growth of the assimilation surface of the carrot leaves: $1-15^{\text {h }}$ of July; $2-15^{\text {th }}$ of August; $3-15^{\text {th }}$ of September

According to the literature data given in V.T. Krasochkin work [124] the greater the number and the surface of leaves at the beginning of the vegetation, the greater harvest yields sugar beets. Our experimental data obtained are consistent with the literature data [124], the higher intensive growth of the foliage and assimilation surface of the leaves had a positive effect on the formation of root crops (Pictures 4.7 and 4.8). 


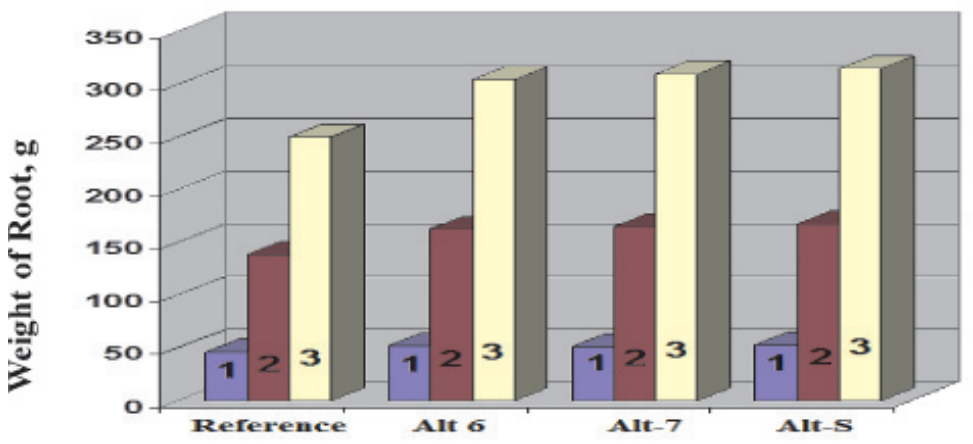

Picture 4.7. Influence of the preparations on dynamics of the sugar beet root weight growth: $1-10^{\text {th }}$ of July; $2-10^{\text {th }}$ of August; $3-10^{\text {th }}$ of September

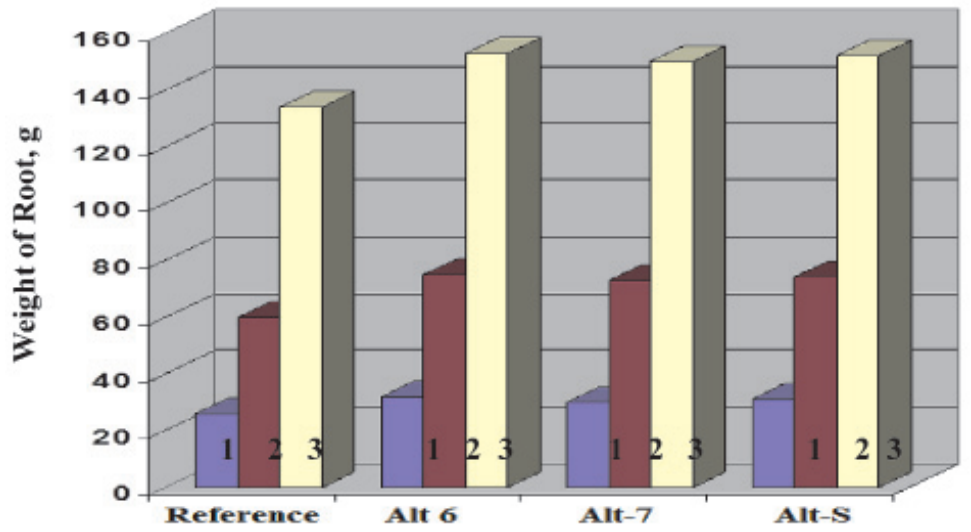

Picture 4.8. Influence of the preparations on dynamics of the carrot root weight growth: $1-15^{\text {h }}$ of July; $2-15^{\text {th }}$ of August; $3-15^{\text {th }}$ of September

Based on the experimental studies the change of the biometric parameters was defined both for beet and carrot during the application as growth stimulants the new piperidine derivatives. These results indicate the growth of the length and diameter of the root crops when the stimulants are applied at the optimal dose of $0.001 \%$ (Table 4.20 , Pictures 4.9 and 4.10). 
Table 4.20

Impact of the preparations Alt-6, Alt-7 u Alt-S

on the biometric parameters of beet and carrot roots

\begin{tabular}{|c|c|c|c|}
\hline Variant & Length, cm & Diameter, cm & Root Index \\
\hline \multicolumn{4}{|c|}{ Beetroot } \\
\hline Reference (water) & $10,8 \pm 0,1$ & $5,9 \pm 0,2$ & 1,83 \\
\hline Alt-6 & $12,7 \pm 0,1$ & $6,9 \pm 0,2$ & 1,82 \\
\hline Alt-7 & $12,2 \pm 0,1$ & $6,5 \pm 0,3$ & 1,87 \\
\hline Variant & Length, cm & Diameter, cm & Root Index \\
\hline Alt-S & $11,6 \pm 0,2$ & $6,8 \pm 0,2$ & 1,70 \\
\hline \multicolumn{4}{|c|}{ Carrot } \\
\hline Reference (water) & $14,0 \pm 0,7$ & $3,3 \pm 0,1$ & 4,23 \\
\hline Alt-6 & $16,5 \pm 0,8$ & $3,6 \pm 0,2$ & 4,58 \\
\hline Alt-7 & $16,4 \pm 0,8$ & $3,7 \pm 0,2$ & 4,43 \\
\hline Alt-S & $16,5 \pm 0,7$ & $4,0 \pm 0,2$ & 4,12 \\
\hline
\end{tabular}

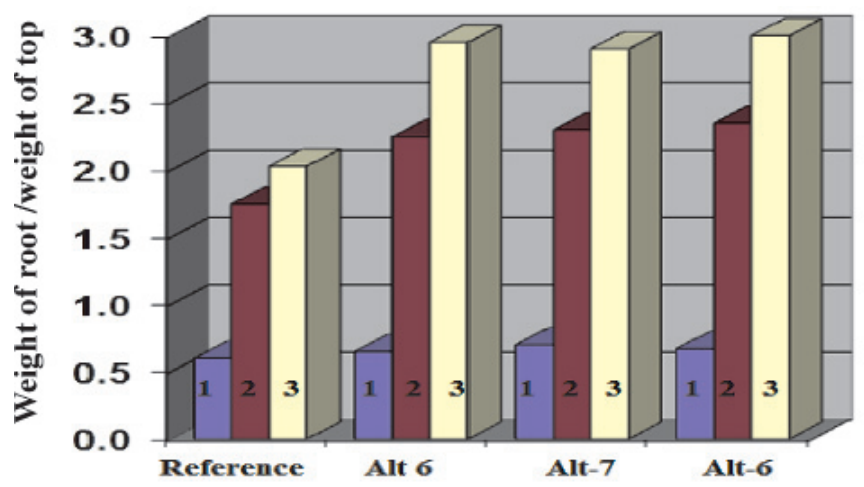

Picture 4.9. Influence of the preplant seed treatment by 0,001\% solutions of the preparations on the beet ratio of weight of root to weight of top: $1-10^{\text {th }}$ of July; $2-10^{\text {th }}$ of August; $3-10^{\text {th }}$ of September

Thus, the treatment of carrots and beets seeds by Alt-6, Alt-7 and Alt-S preparations the increase of the root system of plants, leaf area, accelerating photosynthesis took place. Besides, the photosynthesis as the basis of growth and development of plants, accumulation of chemical compounds, and hence, the biomass can be related to other physiological parameters, including change of chemical composition. The increase in the volume and weight of the roots and 
root crops leads to an intensification of their absorbency and synthetic capacity, intensification of the mass transfer of ions and nutrients through the plant, which promotes intensive growth of sprouting and the formation of new bodies.

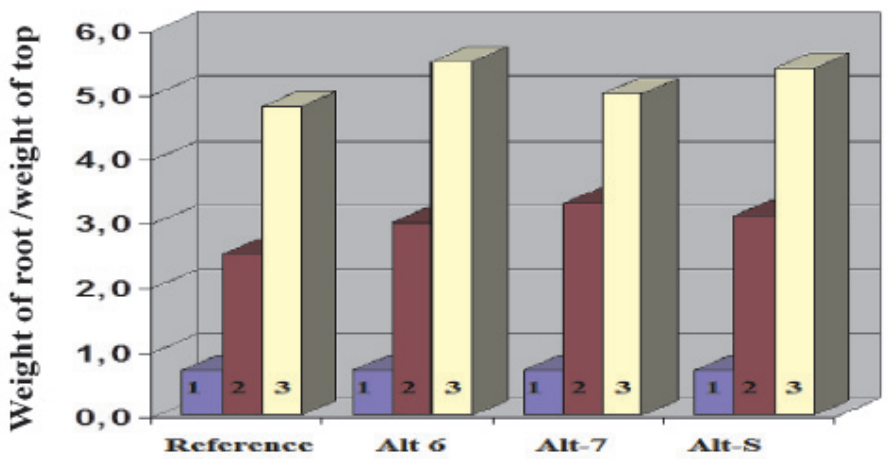

Picture 4.10. Influence of the preplant seed treatment by 0,001\% solutions of the preparations on the carrot ratio of weight of root to weight of top: $1-15^{\text {h }}$ of July; $2-15^{\text {th }}$ of August; $3-15^{\text {th }}$ of September

\subsection{Impact of the growth stimulating piperidine derivatives ALT-6, ALT-7, ALT-S on growth and resistance of corn and mustard to temperature fluctuations and dehydration}

The ground and air environment is characterized by a large scale of temperature fluctuations. In most areas of the land the daily and annual temperature ranges make dozens of degrees. Huge temperature swings in day and night temperatures and short night frosts occur very often in the spring during planting of the crops. And that is why in agriculture low temperatures are the main cause of damage and often death of the plants that require additional costs to re-plant and lead to the late timing of flowering and fruit ripening. In this regard, special attention is paid to the preservation of the viability of the land plants, as the temperature conditions of the environment is one of the most important factors determining the growth and development of plants.

It is known that each type, species of the plant varieties is pertaining to a certain temperature. Thus, ground leafy plants grow mostly in a wide temperature range, i.e. they are eurythermic. Their life interval in an active state extends from +5 to $+55^{\circ} \mathrm{C}$, and their productivity is maintained up to $40^{\circ} \mathrm{C}$ 
Plants of the continental areas develop well when the temperature of the night period is by $10-15^{\circ} \mathrm{C}$ lower than the day temperature, i.e, a temperature difference of $5-10^{\circ} \mathrm{C}$., and tropical plants retain a high yield with the temperature difference of not more than $3^{\circ} \mathrm{C}$. On the basis of experimental studies the authors of works [125-126] found that the effect of the low positive temperature during the growing season leads to disruption of the physiological processes in such plants as cucumber, tomato, rice, cotton, corn and others. The temperature drop at the beginning and end of the growing period results in a significant reduction in crop yields, it can reach $50 \%$.

To increase the cold resistance of plants there is a common method of the seedlings hardening by the low positive temperatures. However, it is quite a complicated process compared to the cheaper and more efficient method the preplant treatment of seeds by the physiologically active substances. Search and synthesis of the analogues of phytohormones and compounds that have antioxidant activity is actively conducted in recent decades.

Many studies demonstrated the possibility of increasing cold resistance by treating the cultures of synthetic growth regulators [125-127]. Particularly noteworthy are synthetic growth regulators, which are highly effective in very small doses at which the high germination rate is kept, productivity increases and the quality of fruits improves [127].

One of the objectives of our research was to determine the optimal concentrations of Alt-6, Alt-7, Alt-S preparations which maximally promote germination and growth of corn and mustard at varying temperatures. Stability of corn and mustard to temperature changes was studied at temperatures of 15,20 and $25^{\circ} \mathrm{C}$. For this purpose the plant seeds were germinated at these temperatures, treating them by the solutions of Alt- 6 , Alt-7 and Alt-S of different concentrations ranging from 0,00001 to $0,01 \mathrm{mg} / \mathrm{l}$. In a reference experiment for the seeds treatment the tap water was used. The experimental data are shown in Table 4.21 and Picture 4.11.

The most effective concentration affecting the germination of seeds is $0,001 \%$ (Table 4.21 ). This agrees with the data obtained from processing ща the other vegetable and grain crops. The germination of corn seeds treated by $0,001 \%$ solution of the preparations Alt- 6 , Alt- 7 and Alt-S, respectively, at $T=25^{\circ} \mathrm{C}$ increases by 4,$6 ; 5,6 ; 5,7 \%$ compared to water reference. In experiments with the mustard treated by $0,001 \%$ solution of the preparations Alt-6, Alt-7 and Alt-S the seeds germination at $T=15^{\circ} \mathrm{C}$ increases, respectively, by 6,$4 ; 6,6 ; 7,1 \%$, and at $T=25^{\circ} \mathrm{C}$ by 4,$5 ; 5,3 ; 5,5 \%$ compared to the reference test. 


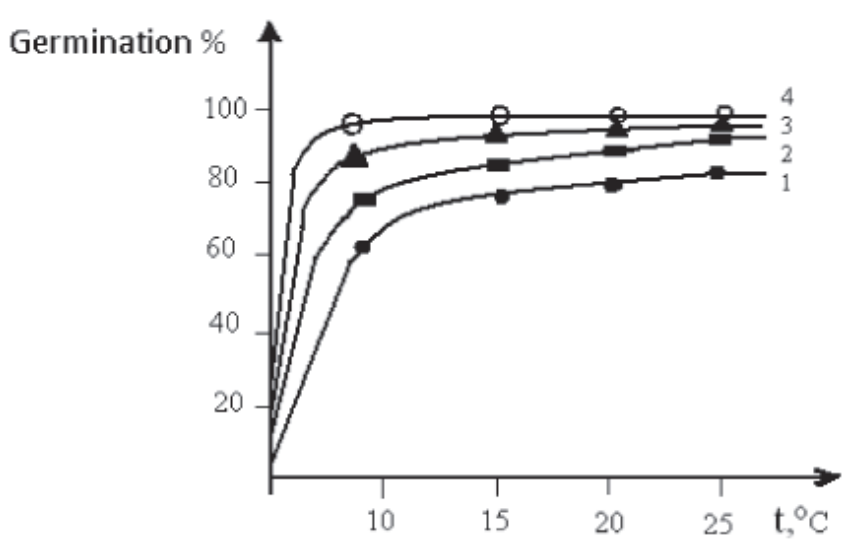

Picture 4.11. Impact of Alt-6, Alt-7 and Alt-S preparations (0,001\%) on germination of corn seeds at different temperatures under germination time of 12 days and nights:

$$
\text { 1-water; } 2 \text {-Alt-6; } 3 \text {-Alt-7; } 4 \text {-Alt-S }
$$

There was a significant increase in seed germination both corn and mustard while treating them by the biologically active preparations at the increasing temperature. At temperatures $\leq 10^{\circ} \mathrm{C}$ the plants seeds germinated much more slowly than at higher temperatures. Difference of the germination, between the temperature of 10 and $25^{\circ} \mathrm{C}$ made not less than $15 \%$. Efficiency of the impact of the preparations on the germination of corn and mustard seeds was mostly pronounced at the low temperatures.

The measurement of the growth parameters of the corn and mustard seedlings confirmed the efficiency of their seeds treatment by the preparations of Alt-6, Alt-7 and Alt-S both at the optimal and lower temperatures. The accelerated growth of axial organs (root and sprouting) was observed both at the low and high temperatures, indicating the potential of piperidine derivatives to increase the stability of the young plants to the low temperatures.

At the temperature of $15^{\circ} \mathrm{C}$ on the 6th day of germination the root length of corn seeds treated by the preparations of Alt- 6 , Alt-7 and Alt-S exceeded, respectively, the reference values by 22,$7 ; 31,4 ; 32,7 \%$, at $25^{\circ} \mathrm{C}$, these values corresponded to 15,$7 ; 11,8 ; 11,4 \%$. At $25^{\circ} \mathrm{C}$ and 12 days and nights of germination period the root and seedling sizes significantly higher compared to the reference. For example, for Alt- 6 for the corn root the growth makes 3,8\%, for sprouting it makes 5,7\% (see Table 4.22). 
Table 4.21

Impact of Alt-6, Alt-7 and Alt-S preparations on germination of corn seeds and mustard at $T=25^{\circ} \mathrm{C}$ and mustard at $T=25^{\circ} \mathrm{C}$ (the numerator) and $T=15^{\circ} \mathrm{C}$ (denominator) $\%$

\begin{tabular}{|c|c|c|c|c|c|}
\hline \multirow{2}{*}{ Object } & \multirow{2}{*}{$\begin{array}{c}\text { Preparation, } \\
\text { mg/L }\end{array}$} & \multicolumn{4}{|c|}{ Germination time, 24 hours } \\
\hline & & 3 & 6 & 9 & 12 \\
\hline \multirow[t]{10}{*}{ Corn } & $\mathrm{H}_{2} \mathrm{O}$ (reference) & $55,2 \pm 1,6$ & $74,1 \pm 1,7$ & $86,0 \pm 1,6$ & $88,1 \pm 1,4$ \\
\hline & Alt-6: 0,0001 & $58,1 \pm 1,3$ & $75,9 \pm 1,8$ & $89,7 \pm 1,8$ & $91,4 \pm 1,7$ \\
\hline & 0,001 & $57,1 \pm 1,5$ & $75,0 \pm 1,4$ & $86,2 \pm 1,3$ & $92,7 \pm 1,5$ \\
\hline & 0,01 & $57,0 \pm 1,7$ & $74,4 \pm 1,9$ & $87,0 \pm 1,5$ & $89,4 \pm 1,3$ \\
\hline & Alt-7: 0,0001 & $59,1 \pm 1,7$ & $76,7 \pm 1,6$ & $90,1 \pm 1,6$ & $92,2 \pm 2,1$ \\
\hline & 0,001 & $57,7 \pm 1,5$ & $76,0 \pm 1,2$ & $87,2 \pm 1,8$ & $93,7 \pm 1,5$ \\
\hline & 0,01 & $57,0 \pm 1,7$ & $75,2 \pm 1,7$ & $87,0 \pm 1,4$ & $90,9 \pm 1,4$ \\
\hline & Alt-S: 0,0001 & $58,9 \pm 1,5$ & $77,4 \pm 1,6$ & $89,9 \pm 1,2$ & $92,4 \pm 1,9$ \\
\hline & 0,001 & $57,3 \pm 1,5$ & $76,3 \pm 1,4$ & $87,7 \pm 1,8$ & $93,8 \pm 2,5$ \\
\hline & 0,01 & $57,8 \pm 1,6$ & $74,8 \pm 1,9$ & $86,9 \pm 1,5$ & $91,4 \pm 1,3$ \\
\hline \multirow[t]{8}{*}{ Mustard } & $\mathrm{H}_{2} \mathrm{O}$ (reference) & $\underline{60,5 \pm 1,5}$ & $\underline{81,1 \pm 1,4}$ & $\underline{88,0 \pm 1,6}$ & $\underline{89,7 \pm 1,4}$ \\
\hline & & $55,5 \pm 2,0$ & $78,3 \pm 1,7$ & $82,0 \pm 1,5$ & $84,2 \pm 1,0$ \\
\hline & Alt-6: 0,001 & $69,1 \pm 1,3$ & $\underline{86,7 \pm 1,6}$ & $91,2 \pm 1,5$ & $94,2 \pm 1,9$ \\
\hline & & $65,6 \pm 0,9$ & $82,0 \pm 1,2$ & $88,3 \pm 1,3$ & $90,6 \pm 1,5$ \\
\hline & Alt-7: 0,001 & $69,5 \pm 1,3$ & $\underline{86,9 \pm 1,5}$ & $92,0 \pm 1,8$ & $95,0 \pm 1,1$ \\
\hline & & $64,9 \pm 1,7$ & $\overline{82,9 \pm 1,3}$ & $89,0 \pm 1,1$ & $90,8 \pm 1,4$ \\
\hline & Alt-S: 0,001 & $69,9 \pm 1,5$ & $\underline{87,7 \pm 1,4}$ & $92,1 \pm 1,6$ & $95,2 \pm 1,3$ \\
\hline & & $\overline{65,5 \pm 1,0}$ & $\overline{83,0 \pm 1,6}$ & $9,0 \pm 1,4$ & $91,3 \pm 1,8$ \\
\hline
\end{tabular}

The most intensive growth of root and sprouting of seedlings at 15 and $25^{\circ} \mathrm{C}$ it is determined also for the mustard (Table 4.22).

Treatment of the corn and mustard seeds by the preparations Alt-6, Alt-7 and Alt-S made activating effect not only on the growth of the root and sprouting of the seedlings, but also on the morphological parameters of the plants. As it is known, high yields depend on the photosynthetic activity of plants. The indicator is the leaf area, photosynthetic potential, the growth and increase of the entire aboveground biomass [92-95], maintenance of optimal ratios of abiotic factors, like, the light, heat, moisture, regime of carbon dioxide, and mineral nutrition, and others. In general, the amount of the output yield depends on the formation of the photosynthetic apparatus, namely, on the leaf area.

The highest output yield of the top of both corn and mustard as compared with the reference was obtained in the experiments with growth stimulating preparations Alt-6, Alt-7 and Alt-S applied for the seeds treatment (Table 4.22 and 4.23). 
Table 4.22

Effect of 0,001\% solution of growth stimulating preparations on the growth of seedlings axial organs of the plants at the different temperatures and time of germination (the numerator 6 days and nights, denominator 12 days and nights) $\mathrm{mm}$

\begin{tabular}{|c|c|c|c|c|}
\hline \multirow{3}{*}{$\begin{array}{l}\text { The plant, } \\
\text { Variant }\end{array}$} & \multicolumn{4}{|c|}{ Temperature } \\
\hline & \multicolumn{2}{|c|}{$15^{\circ} \mathrm{C}$} & \multicolumn{2}{|c|}{$25^{\circ} \mathrm{C}$} \\
\hline & Root, mm & Sprouting, mm & Root, mm & Sprouting, mm \\
\hline \multirow{3}{*}{$\begin{array}{c}\text { Corn: } \\
\mathrm{H}_{2} \mathrm{O} \text { (reference) }\end{array}$} & & & & \\
\hline & $\underline{15,9 \pm 0,9}$ & $\underline{15,0 \pm 1,1}$ & $\underline{50,9 \pm 1,9}$ & $\underline{68,7 \pm 2,9}$ \\
\hline & $24,0 \pm 1,1$ & $53,9 \pm 1,6$ & $92,9 \pm 2,6$ & $81,7 \pm 2,6$ \\
\hline \multirow[t]{2}{*}{ Alt-6: } & $19,5 \pm 1,4$ & $16,9 \pm 1,9$ & $\underline{58,9 \pm 1,6}$ & $\underline{74,9 \pm 1,5}$ \\
\hline & $28,1 \pm 1,8$ & $58,2 \pm 1,1$ & $98,2 \pm 2,6$ & $84,8 \pm 2,0$ \\
\hline \multirow[t]{2}{*}{ Alt-7 } & $\underline{20,9 \pm 2,1}$ & $15,5 \pm 1,8$ & $\underline{56,8 \pm 1,7}$ & $\underline{78,7 \pm 1,6}$ \\
\hline & $29,0 \pm 1,9$ & $59,3 \pm 0,6$ & $97,9 \pm 2,0$ & $85,1 \pm 2,1$ \\
\hline \multirow[t]{2}{*}{ Alt-S } & $\underline{21,1 \pm 0,9}$ & $16,5 \pm 2,1$ & $\underline{57,7 \pm 1,0}$ & $\underline{76,3 \pm 0,9}$ \\
\hline & $29,2 \pm 1,7$ & $57,9 \pm 0,6$ & $98,7 \pm 2,1$ & $85,3 \pm 1,9$ \\
\hline \multirow{3}{*}{$\begin{array}{c}\text { Mustard: } \\
\mathrm{H}_{2} \mathrm{O} \text { (reference) }\end{array}$} & & & & \\
\hline & $\underline{11,9 \pm 0,6}$ & $\underline{15,0 \pm 1,1}$ & $\underline{31,1 \pm 1,1}$ & $\underline{44,8 \pm 2,0}$ \\
\hline & $14,9 \pm 1,0$ & $33,9 \pm 1,1$ & $75,2 \pm 1,6$ & $53,9 \pm 2,1$ \\
\hline \multirow[t]{2}{*}{ Alt-6: } & $\underline{12,5 \pm 1,1}$ & $\underline{16,9 \pm 1,9}$ & $\underline{33,8 \pm 0,6}$ & $\underline{49,1 \pm 1,5}$ \\
\hline & $28,1 \pm 1,8$ & $38,2 \pm 1,0$ & $78,2 \pm 2,1$ & $56,8 \pm 0,9$ \\
\hline \multirow[t]{2}{*}{ Alt-7 } & $\underline{12,7 \pm 1,3}$ & $\underline{15,5 \pm 1,8}$ & $\underline{32,5 \pm 1,7}$ & $\underline{48,7 \pm 1,2}$ \\
\hline & $29,0 \pm 1,9$ & $39,3 \pm 0,7$ & $77,3 \pm 1,8$ & $55,6 \pm 1,1$ \\
\hline \multirow[t]{2}{*}{ Alt-S } & $\underline{11,1 \pm 0,5}$ & $\underline{16,5 \pm 2,1}$ & $\underline{32,9 \pm 0,7}$ & $\underline{46,3 \pm 0,6}$ \\
\hline & $29,2 \pm 1,7$ & $37,9 \pm 0,3$ & $78,1 \pm 1,6$ & $55,3 \pm 1,2$ \\
\hline
\end{tabular}

While using the preparations in the budding phase the mustard plant heights increase by $3,5 \mathrm{~cm}$ in the flowering stage by $7-10 \mathrm{~cm}$ compared with the reference experiment plan. Stimulation of the photosynthetic process is determined based on the calculation of the leaf area.

To determine the resistance of the plants to the cooling the experiments were conducted to define the permeability of the cell membranes as this parameter is a criteria of damaging action. In order to identify the growth stimulating actions of Alt- 6 , Alt-7 and Alt-S preparations on the changes of the electrolytes egress from the cells the treated seeds of the corn and mustard were conditioned at $5^{\circ} \mathrm{C}$ during 24 hours. 
Table 4.23

Dynamics of linear growth of mustard from sowing to flowering, $\mathrm{cm}$

\begin{tabular}{|c|c|c|c|c|}
\hline \multirow{2}{*}{$\begin{array}{c}\text { Variant } \\
\text { of Experiment }\end{array}$} & $\begin{array}{c}\text { Concentration of } \\
\text { the preparation } \\
\text { solution for seeds } \\
\text { treatment, \% }\end{array}$ & \multicolumn{2}{|c|}{$\begin{array}{c}\text { Average height of the } \\
\text { plant in phases of }\end{array}$} & \multirow{2}{*}{$\begin{array}{c}\text { Leaf Area in the } \\
\text { phase budding - } \\
\text { flowering thousand } \\
\text { of } \mathbf{~ M}^{\mathbf{2}} / \mathbf{h a}\end{array}$} \\
\hline Reference & - & $44,2 \pm 1,7$ & $66,1 \pm 2,2$ & $20,8 \pm 2,9$ \\
\hline Alt-6 & 0,001 & $47,4 \pm 2,1$ & $73,2 \pm 2,9$ & $21,9 \pm 2,6$ \\
\hline Alt-7 & 0,001 & $49,0 \pm 1,6$ & $74,5 \pm 1,9$ & $21,0 \pm 3,2$ \\
\hline Alt-S & 0,001 & $47,7 \pm 1,9$ & $76,0 \pm 2,3$ & $22,2 \pm 1,9$ \\
\hline
\end{tabular}

Table 4.24

The impact of treatment of corn and mustard seeds by the preparations Alt-6, Alt-7 and Alt-S on the electrolytes egress after cooling the plants $\left(24\right.$ hours, $\left.5^{\circ} \mathrm{C}\right), \%$ of the complete egress

\begin{tabular}{|c|c|c|c|}
\hline \multirow{2}{*}{ Variants, preparation, \% } & \multicolumn{2}{|c|}{ Electrolytes Egress } & \multirow{2}{*}{ DC } \\
\hline & Before cooling & After cooling & \\
\hline \multicolumn{4}{|c|}{ Corn } \\
\hline \multicolumn{4}{|c|}{ Germination temperature $15^{\circ} \mathrm{C}$} \\
\hline $\mathrm{H}_{2} \mathrm{O}$ (reference) & $6,0 \pm 0,2$ & $29,8 \pm 0,3$ & $25,6 \pm 0,6$ \\
\hline Alt-6 $(0,001 \%)$ & $6,1 \pm 0,3$ & $30,3 \pm 0,7$ & $25,1 \pm 0,3$ \\
\hline Alt-7 $(0,001 \%)$ & $6,2 \pm 0,1$ & $28,8 \pm 1,3$ & $26,1 \pm 0,9$ \\
\hline Alt-S $(0,001 \%)$ & $6,1 \pm 0,4$ & $30,2 \pm 1,1$ & $26,2 \pm 1,3$ \\
\hline \multicolumn{4}{|c|}{ Germination Temperature $25^{\circ} \mathrm{C}$} \\
\hline $\mathrm{H}_{2} \mathrm{O}$ (reference) & $6,6 \pm 0,2$ & $35,0 \pm 1,3$ & $29,9 \pm 0,6$ \\
\hline Alt-6 $(0,001 \%)$ & $6,7 \pm 0,3$ & $35,9 \pm 0,9$ & $30,6 \pm 1,3$ \\
\hline Alt-7 $(0,001 \%)$ & $6,8 \pm 0,7$ & $35,8 \pm 1,3$ & $31,0 \pm 0,9$ \\
\hline Alt-S $(0,001 \%)$ & $6,7 \pm 0,6$ & $36,2 \pm 1,1$ & $30,9 \pm 1,3$ \\
\hline \multicolumn{4}{|c|}{ Mustard } \\
\hline \multicolumn{4}{|c|}{ Germination Temperature $15^{\circ} \mathrm{C}$} \\
\hline $\mathrm{H}_{2} \mathrm{O}$ (reference) & $20,2 \pm 1,2$ & $40,0 \pm 2,3$ & $33,3 \pm 1,6$ \\
\hline Alt-6 $(0,001 \%)$ & $26,7 \pm 1,3$ & $45,9 \pm 1,6$ & $30,6 \pm 1,3$ \\
\hline Alt-7 $(0,001 \%)$ & $26,8 \pm 1,7$ & $45,8 \pm 1,3$ & $33,0 \pm 1,9$ \\
\hline Alt-S $(0,001 \%)$ & $27,0 \pm 0,9$ & $44,9 \pm 1,4$ & $32,9 \pm 1,4$ \\
\hline \multicolumn{4}{|c|}{ Germination Temperature $25^{\circ} \mathrm{C}$} \\
\hline $\mathrm{H}_{2} \mathrm{O}$ (reference) & $22,2 \pm 1,2$ & $43,5 \pm 1,3$ & $39,9 \pm 0,9$ \\
\hline Alt-6 $(0,001 \%)$ & $28,7 \pm 1,3$ & $44,9 \pm 1,8$ & $40,6 \pm 1,3$ \\
\hline Alt-7 $(0,001 \%)$ & $29,8 \pm 1,1$ & $43,8 \pm 1,9$ & $41,1 \pm 0,9$ \\
\hline Alt-S $(0,001 \%)$ & $27,9 \pm 0,8$ & $46,2 \pm 1,3$ & $41,9 \pm 1,3$ \\
\hline
\end{tabular}


The results of experimental tests are shown in Table 4.24. It can be seen that the treatment of seeds of both corn and, mustard by the preparations slightly increase the electrolyte egress before the cooling compared to the reference where the seeds were treated by pure water. After cooling some increase in the electrolyte egress from the seeds treated by Alt-6, Alt- 7 and Alt-S is observed.

On the basis of the experimental data, we calculated the Damage Coefficient (DC) (Table 4.24). In all the variants of the seeds treatment by the preparations we observed a lower value of the $\mathrm{DC}$ after germinating at $15^{\circ} \mathrm{C}$ as compared to the germination at $25^{\circ} \mathrm{C}$ this is confirming the hardening effect of the low temperature for the studied crops.

\section{CHAPTER CONCLUSIONS}

1. Evaluating the effect of the newly synthesized preparations AltS, Alt-6, Alt-7 on the output yields, quality of the crops (potato, beet, carrot, radish, winter wheat, and others.), it can be concluded that these compounds are the factors that impact on the formation of the root system, the growth of assimilation surface, and finally on the improvement of the plants productivity as a result of the formation of a strong plant. These preparations have a complex effect on the plants; they are able not only to accelerate the growth and development stages, but also to protect against diseases, in particular against bacterial rot, scab and other fungal diseases.

2. Out of three piperidine derivatives - Alt-S, Alt-6, Alt-7 on the growth and development of the plants examined, namely on stimulation of the leaf formation process, the formation of the assimilation surface of the leaves, on the improvement of the structure of roots and on the increase of the plants yield at the preplant treatment of seeds the active effect has the sulfur containing preparation Alt-S.

3. It was determined that the most intense evocation of the potato tuber buds is observed while treating the seed materials by the $0,001 \%$ of 1 -methyl-4- (2-thio-picoline-amine) piperidine. At this concentration of the preparation also it was defined that the yield of the studied culture enhances due to strengthening of the tubers formation and increase of their weight.

4. The experimental data suggest that the use of the preparations Alt-6, Alt-7, Alt-S during the preplant seeds treatment prevents the accumulation of nitrates and nitrites in the plants, enhancing their consumption on the synthesis of the complex organic compounds that are useful for human 
nutrition. The application of the new piperidine derivatives opens the possibility of realization of the huge biological potential of the plant body, set by its genotype.

5. Treatment of corn and mustard seeds by the preparations Alt-6, Alt7 and Alt-S significantly enhanced the stability of cell membranes during cooling. This is manifested in a decrease of the electrolytes exosmosis induced by cooling at $5^{\circ} \mathrm{C}$ for 24 hours. These preparations can be recommended for the treatment of the corn and mustard seeds in order to enhance germination and improve growth under conditions of the unfavorable low temperatures. 


\section{CONCLUSION}

A literature review and analysis of the work of many enterprises have served as the basis for the assessment of contemporary critical situation connected with the problem of waste. Experience to date has shown that the use of man-made waste as raw materials is rational ways for their recycle. On one side, this approach can reduce impact on the environment, on other side it ensures more sustainable utilization of scarce and non-renewable natural resources replacing primary raw material to the secondary ones.

In this work we solved an urgent task in the field of environmental protection and rational use of natural resources for example, sulfur-containing waste ferrous metals, coke and petroleum industries.

A series of effective environmental technologies was developed by authors for the synthesis of various inorganic ammonium salts (persulfate, hydrosulfate, sulfate, thiosulfate, etc.) and organic heterocyclic compound $\mathrm{s}$ (piperdine derivatives). It was obtained previously unexplored bioactive compounds from the utilizing products of industrial waste, namely new disinfectants, growth stimulants and development of vegetable and cereal crops and also the ways of their implementation was established.

New fields for ammonium salts application have been found: new disinfectants have been created, namely, "Zhezpen-1" that is made as the mixture of persulfate (30-35\%) and ammonium bisulfate (70-65\%), "Zhezpen-2" including persulfate (30-38\%), hydrogen sulfate (69-61\%), and surfactant penazolin $(0,6-1 \%)$, "bactericide" which is made of persulfate $(27,0-39,0 \%)$ and ammonium bisulfate $(70,1-58,0 \%)$ and cationic surfactant-alkylimdazolin $(1,2-0,7 \%)$. These preparations have a sufficiently high bactericidal activity, they are odorless, soluble in water, transportable, have low toxicity $\left(\mathrm{LD}_{50}=910 \mathrm{mg} / \mathrm{kg}\right)$, decompose in the environment without harmful residues. According to the results of industrial tests of the preparations are recommended as disinfectants for sanitation of the livestock facilities with tuberculosis and brucellosis concern, for the topical treatment and prevention necrobacillosis and other diseases of farm animals.

Thus, the above experimental data testify to the increase in the chlorophyll content in leaves, and as a result, correspondingly the efficiency of photosynthesis is enhanced. The unique properties of Alt-6, Alt-7, Alt-S provide for their functional impacts on plants: stimulation of the induced immunity to the pathogens, enhancement of the resistance to adverse environmental factors, activating of the growth stimulating processes, increase of the output yields. 


\section{REFERENCE LITERATURE}

1. Akbassova A.D., Sainova G.A. Ecology - Almaty: Bastau, 2003. -290p.

2. Akbassova A.D., Mukhanov N.S., Sunakbayeva D.K., Akhmetov N.A. Providing environmental safety based on the use of disinfectants, obtained by recycling of sulfur waste // Measures on saving biodiversity of Turkestan region: the joint action of the IKTU and WWF. Proceedings of the International Conference (22-23 February 2011). - Turkestan: Publishing House of IKTU, 2011. - P. 45-48.

3. Akbassova A.D., Kolushpayeva A.T., Sainova G.A. Innovative patent "1- methyl-4- (2- tiopikolinamino) piperidine as growth stimulant of plant" № 25210 (Kazakhstan).

4. Akbassova A.D., Raimberdiyev T.P., Sainova G.A., Sunakbayeva D.K., Akhmetov N.A. Innovative Patent “Desinfectant” № 25632 (Kazakhstan).

5. Akbassova A.D., Kolushpayeva A.T., Sainova G.A., Sunakbayeva D.K., Akhmetov N.A. Influence of nt "Dibiologically active compounds, piperidine derivatives to clean soil from heavy metals mustard // Bulletin of KazNTU, Almaty, 2011. - N2 (48) Part 2. - P. 61-64.

6. Akbassova A.D., Yunusov N.H., Bisenova L.E. Innovative maintenance of oil waste disposal // Natural resource use and problems of anthroposphere Bulletin of M.Kh.Dulaty Taraz State University. - Taraz, 2010. № 3 - P. 55-60.

7. Akbassova A.D., Uysimbayeva Zh., Kolushpayeva A.T. Assessing the impact of preparation Alt $-6,7, \mathrm{~S}$ for the development and quality of potatoes // Bulletin of Taraz state University 2010, № 3 - P. 77-80.

8. Akbassova A.D., Kolushpayeva A.T., Uysimbayeva Zh, Sainova G.A, Turlybekov U. Synthesis of new biologically active compounds of piperidine series with using coke industry wastes // International Scientific and Practical Conference. "Prospects for the development of industry and the agricultural sector of Kazakhstan: science, innovation, social and economic aspects" Kyzylorda, 2010. - P. 210-213.

9. Akbassova A.D., Kolushpayeva A.T., Sainova G.A., Turlybekov U. Synthesis and study of the properties of new active thio compound piperidine series // Proceedings of the international scientific- practical conference "Youth and Science: Reality and Future". - Nevinnomyssk, Russia, 2009. - P. 112-115. 
10. Akbassova A.D., Sainova G.A., Sunakbayeva D.K., Abdullayev K.Sh. A comparative study of the corrosion activity of the preparation "bactericide" // Proceedings of the international scientific- practical conference. "The new in the safety of life-sustaining activity" - Almaty, KazNTU, 2008. - P. 68-71

11. Sainova G.A. Use of a mixture of bentonite clay and the waste of sugar production for the detoxification of soils along highways. // Third. Int. Scient. Conference "Eurasian Transport of Twenty-first Century", October 15-17, 2008 - Almaty KazATC 2008, t.2 - P. 59-63.

12. Akbassova A.D., Sainova G.A., Sunakbayeva D., Shorayeva N.A. The use of sulfur-containing waste products disposal to disinfect vehicles. // Proceedings of the Int. Scient. Conference "Eurasian Transport Twenty-first Century", October 15-17, 2008. - Almaty KazATC 2008, T. 2 - P. 77-82.

13. Sainova G.A., Sunakbayeva D.K., Akbassova A.D., Duambekov M.S. A technology of obtaining bactericide preparation from sulfur wastes // Bulletin, 2008, № 8. - P. 36-38.

14. Abdullayev K.Sh., Sunakbayeva D.K., Sainova G.A. Production waste is a potential source of secondary raw materials // International scientific-practical conference. "Prospects for the development of industry and the agricultural sector of Kazakhstan: science, innovation, social and economic aspects" Kyzylorda, 2010.- P. 204-208.

15. Sainova G.A., Akbassova A.D., Isakov O.A. Innovative patent "Disinfectant”. № 19673 (Kazahstan)

16. Urazbekov A.K., Bektenov M.B., Akbassova A.D. Physico-chemical properties of the waste in oil materials of railways // Bulletin of the Research Institute of Railway Transport. - Astana, 2007., № 4. - P. 42-46.

17. Sainova G.A., Kozhamberdiev KO., Akbasova A.D., A.S. Shanlayakov. The use of waste sugar plants for sewage treatment of the enterprises of the railway network // Bulletin of KazGASA - Almaty, 2007. № 1 (23). - S. 156-159.

18. Akbassova A.D., Sainova G.A., Bakhmagambetova G.B. Recycling, liquidation and use of production wastes from Zhezkazgan copper-smelting plant // Proceedings of the international scientific-practical conference.100th anniversary of A.Zh.Mashanova - Almaty, 2006. - P. 145-148.

19. Akbassova A.D., Sainova G.A., Akbassov A.Zh. The use of washing sulfuric acid as a secondary raw material // M.H.Dulati Taraz state University Bulletin 2006, № 3 - P. 45-48.

20. Akbassova A.D., Zhaksybayeva G.S. Theoretical Foundations of Environmental Protection // Methodical instruction, KazNTU, 2006. 36p. 
21. Kolushpayeva A.T., Tleubayeva A.A. Plant growth stimulants. Copyright certificate № 52495 20.07.2006.

22. Akbassova A.D., Zhamalbekov E.U., Kabylbekov T.K., Kolushpayeva A., Rysbekova K., Sainova G.A., Sandibekova M.N. Environmental encyclopedia. Almaty: Bastau. $-2007-303$ p.

23. Sainova G.A. Use of a mixture of bentonite clay and the waste of sugar production for the detoxification of soils along highways. // Third. Int. Scient. Conference "Eurasian Transport of Twenty-first Century", October 15-17, 2008 - Almaty KazATC 2008, T 2 - P. 59-63.

24. Akbasova A.D., Duambekov M.S., Sainova G.A. Soil protection. Textbook. Astana Fiolanta, 2008. - 296p.

25. Sainova Gauhar, Ozler Mehmet, Sunakbayeva Dilara. Kuş gübresinden yararlanma-sının rasyonel yöntemi. Turkey, 2012, Congress.

26. Sainova G.A. Obtaining bactericide preparation from oil industry wastes. // Materials of the International scientific-practical conference. 25th anniversary KazGASA "Regional problems of health and safety (5-6 May 2005) - Almaty KazGASA, 2005. - P. 79-81.

27. The ecological state of Environment of Kazakhstan and measures for its improvement: State report, 1995-2000. Almaty, 2000.

28. Ecology and life safety: College textbook/ D.A. Krivoshein, L.A. Muravei, N.N. Roeva and etc.; Edited by L.A. Muravei. - M.: UNITY-DANA, 2000. - $447 \mathrm{p}$.

29. Wastes: The ways of minimization and prevention: book of reports. Edited by A.A. Zharmenov Corresponding member of NAS of RoK. - Almaty, 2002. - 132p.

30. Grinin A.S., Novikov V.N. Industrial and domestic waste: storage, disposal, recycling. - M.: FAIR - PRESS, 2002. - 336p.

31. Maslov N.N., Korobov U.I. Environmental protection in rail transport. - M.: Transport, 1996. - 238p.

32. Umarov A.D., Celikov V.V., Zalcman M.D., Kaspakbayev K.S., Kazhigulov A.K., Cygankov S.G. Ecological safety in transport: college textbook. -Almaty, 1999. - $352 \mathrm{p}$.

33. Mazur I.I., Moldavanov O.I. Environmental Engineering Course: college textbook / edited by I.I.Mazur. - M.: Higher School, 1999. - 447p.

34. Voronsky V.A.Applied Ecology. - Rostov on Don: Phoenix, 1996. - 512p.

35. Belyev E.U., Belyeva L.E. The use of vegetable raw materials in solving environmental problems // Chemistry for Sustainable Development.2000. № 8. - P. 755-772. 
36. Panin M.S. Chemical ecology: College textbook / Edited by Kudaibergenov S.E. - Semipalatinsk: Semei State University named after Shakarim, 2002. $-852 \mathrm{p}$.

37. Benyamoasky D.I. Thermal methods of disposal of solid waste. 1979. $-234 \mathrm{p}$.

38. Madiyev M.R. Sanitary purification of cities from the questions of municipal solid waste: Almaty 2002. -116p.

39. Senin V.N. Energy and Environment. - M., 1987. - 40p.

40. Ilyin S. N. Resource-saving technology for processing pig manure to produce biogas: Author. Dis. cand. tehn. sciences: 05.20.01/ S. N. Ilyin. Ulan-Ude: 2005. -23 p.

41. Dubrovin A.V. Resource- automated technology of processing poultry manure in order to best use the energy of the feed mixture. // Ecology and Agriculture Technology/ Northwestern. Scientific research. Institute of mechanization and electrification of villages. households va. - Saint Petersburg, 2009. - T. 3. - P. 107-113

42. Dabaeva M.D. Ecological and safe disposal of waste: monograph / M. D. Dabaeva, I. Fedorov, A.I. Kulikov; Buryat. State Agricultural Academy. Ulan-Ude: Publishing House of the BSAA, 2001. - 94 p.

43. Tikhomirov A.G., Kirin V.V., Kustov L.Y., Budanitsky I.M. Municipal solid waste and important source of energy and resource // Industrial Energy. - 1990. - № 12. - P.15-19.

44. Egemberdiev M.N. Influence of bacterial contamination of municipal solid waste on the environment of Almaty city: thesis of a Cand.Tech.Sci. Almaty, 1998. - 126p.

45. Ruchnikova O.I. Environmental technology: review of the main uses of oil waste as secondary raw materials // Engineering Ecology, № 1, 2004. - P.2-15

46. Khairov G.B. The environmental problems in the oil industry of the Republic of Kazakhstan // Oil and Gas. - 2001. - № 3. - P.93-98.

47. Kireev M.A., N.K. Nadirov. Environmental problems in the oil industry of Kazakhstan and ways of their solution // Oil and Gas. - 1998. - № 4. - P.130-137.

48. Izteleuova M.B. Modern problems of ecology // Oil Oil and Gas. 2002. -№ 1. - P. 48-51.

49. Menkovsky MA, Yavorsky V.T.Technology sulfur. - M.: Chemistry, 1985. $-328 \mathrm{p}$.

50. Modern approaches to treat scabies. On the site www.dermatolog4 you.ru. 
51. Pilipenko A. T., Pyatnicki I. V. Iodometry // Analytical chemistry. M.: Chemistry, 1990. - P. 417-421. - 848 p.

52. Spiridonov F.M., Zlomanov V.P. 13.1 Thiosulfuric acid and thiosulfates // Chemistry chalcogen. Education guidance. - M.: MGU, 2000. -396 p.

53. Derek Barton, W. David Ollis. Comprehensive Organic Chemistry, vol. 3, Sulphur Compounds. - M.: Chemistry, 1983. - T. 5. -720 p.

54. Arens V. Zh. Geotechnological methods of mining. - M.: Nedra, 1975. - T. 3. $-480 \mathrm{p}$.

55. Zipperian D., Raghavan S., Wifson J. Gold and silver extraction by ammonical thiosulfate leaching // Hydrametalurgy, 1988, V.9, № 3, P. 9-14.

56. Yulushev I.G. Soil and agrochemical bases of adaptive- landscape systems of agriculture organization: Textbook. - M.: Academic Project; Kirov, Constanta, 2005. - 368 p.

57. Akbassova A.D., Raimberdiev T.P., Sainova G.A., Sunakbaeva D.K., Akhmetov N.A. Disinfectant. Patent RoK 25632, Number 73,658 was published in the Bulletin. Number 4, 16.04.2012 (Astana).

58. Akbassova A.D., Umarov M.O., Imangaliev A.K. and others. Disinfectant.

Copyright certificate USSR № 1667871, Cl. 61. A Publ. in the bulletin № 29. on 07/08/92.

59. Akbassova A.Zh., Kolushpaeyeva A.T., Sainova G.A., Sunakbayeva D.K. Obtaining bioactive preparation treating oil and gas production sulfur containing waste// Proceedings of the Third International Scientific and Practical Conference "Problems of innovative development of the oil and gas industry". - Almaty, KBTU, 2010. - P. 88-92.

60. Sunakbayeva D.K. Using disinfectants for veterinary practice. Shymkent: Medicine, 2009. - № 3. - P.123-125.

61. Zinchenko V.A. Chemical protection of plants: tools, technology and environmental safety. - M.: Kolos, 2005.- 436 p.

62. Akbasova A.Zh. Ecological bases of industrial technologies. - Almaty: KazNTU, 2005. - 74p.

63. Tsyganyuk P.L. The physiologically active substances for vegetable crops // The new gardener and farmer. - № 6. - 2000. - P. 43

64. Rosa Margesin, Franz Schinner (Eds.) Manual of soil Analysis Monitoring and assessing soil bioremediation. - Berlin, Heidelberg: Springer-Verlag, 2005. $-366 \mathrm{p}$. 
65. Remediation engineering of contaminated soils / Donald L. Wise, Debra J. Trantolo, Edward J Cichon, Hilary I. Inyang, Ulrich Stottmeister. - New York Basel: Marcel Dekker, Inc., 2000. - 996 p.

66. Gafurov R.G. Effective stress protectors and biobate retardants for food and industrial crops //Science - for production, 1999, № 8. - P. 39-42.

67. Petrenko D.S. Pyridine and quinoline base. - M.: Metallurgy, 1973. $-327 \mathrm{p}$.

68. Murzagulova K.B. Learning the basics of developing technology of pilot production of painkillers pyridine series. Author's abstract. 1999. $-58 \mathrm{p}$.

69. Pozhar B. Practical Application of chemicals stimulators and inhibitors in improving productivity and storage. - Budapest, 1965. $-201 \mathrm{p}$

70. Shevelukha V.S. Plant growth and its regulation in ontogenesis. - M.: Kolos, 1992. - 598 p.

71. Muzichenko G.F., Nenko N.I., Burlaka S.D., M.A. Sibiryakova, Kopan A. Effectiveness of new derivatives of $4-\mathrm{N}-\mathrm{X}$ aminopirrolidon-2 which has growth-regulatory and anti-stress activity // Agrochemistry, 2005, number 5. - P. 71-75.

72. Sosnovskih V.Y., V.R. Katyanova. 2,2.6,6 - tetra -4-piperidone// Chemistry of Heterocyclic Compounds. - 1987.- № 7. - P. 948-958.

73. Alimzhanova S.K., A.S. Sharifkanov. Synthesis and transformations of derivatives piperidin -4. - Almaty: Kazakh University, 2000. - 121 p.

74. Lukatkin A.S., Zhamharyan Y.A., Pugayev S.V. Effect of thidiazuron on the productivity of cold resistance and fruit quality of cucumber // Agrochemistry, 2003, № 7. - P. 52-59.

75. Certificate of authorship № 1289868 USSR. A process for preparing 2,2,6,6 -tetramethyl- 4 -oxo-piperidine / A.I. Medvedev, Romanchenko T.S., T.B. Zvegintseva - BI, N 2, 1987.

76. Mishchenko G.L. Vatsuro K.B. Nominal reaction in organic chemistry. - M.: Chemistry, 1976. $-351 \mathrm{p}$.

77. Thomas C. Mannich Reaction Mechanisms // J. Org. Chem. - 1960. V. 25. - № 3. - P. 419-423.

78. Alimzhanova S.K., A.S. Sharifkanov. Synthesis and transformations of derivatives of piperidine -4. Almaty: Kazakh University, 2000. -121 p.

79. Fabor A.E. Selected works. - M.: Nauka, 1961. - 690 p.

80. A method for producing 2,5 - dimethylpiperidine -4// it Sharifkanov AS, Suerbaev H.A., Mamutova A.A., S.S. Sheraliev - 1983. 
81. AS № 1048720 USSR. 1- [ß- hydroxyethyl] piperidine -4 which has the growth activity // Murzagulova K.B., Lukyanets V.N., Sharifkanov A,S., Tokmurzin K.H., Abdykalykova R.A. - 1990

82. Sharifkanov A.Sh., Akhmedov Sh.S.,Murzagulova K.B., Samarin G.I., Galenko - Yaroshevskii P.A., Rihlokain - new local anesthetics which has both anti-inflammatory,anti-arrhythmic and anticonvulsant activity // Pharm. Bulletin of the Republic of Kazakhstan. - 1998, № 18. - P.18.

83. Patent Kazakhstan № 6249. Antiarrhythmic, and anticonvulsant pharmacological agent// Sharifkanov A.S., S.S. Akhmedov, Murzagulova K.B. (Kazakhstan), Galenko Yaroshevskii P.A. (Russia). - BI № 7. - 1999.

84. Kolushpaeva A.T., Alimzhanova S.K., Sharifkanov A.Sh. Synthesis and some transformations of oximes and 1 -methyl- 1,2,5 - trimethylpiperidinium -4 -ones // Bulletin of Kazakh state University. 1998, № 1 - P. 22-24.

85. Azerbaev E.N., Poplavskaja I.A., Kurmanaliev M.N. Chemistry of natural compounds and biologically active substances in Kazakhstan. -Almaty, Science, 1967. - P. 56-59.

86. Averko-Antonovich A.A., Kirpichnikov P.A., Smyslova R.A. Polysulfide oligomers and sealants on their base. - L.: Chemistry, 1983. - $128 \mathrm{p}$.

87. Kolushpaeva A.T. Piperidine derivatives Alt-7 - a new growth stimulator and stressprotector of wheat // News of Science of Kazakhstan, 2009, № 4. - P. 46-49.

88. Tuterev S.L. Scientific bases of induced disease resistance of plants. St.Peterburg, 2002. - 298 p.

89. Nedelkin V.I., Zachernyuk B.A., Andrianova O.B. Organic polymers based on elemental sulfur and its simplest compounds // Russian Chemical Journal 2005, T. XLIX, № 6. - P. 3-10.

90. Hortling B., Borchers K., Lindberg I. Phosphorus and Sulfur, 1981, v. 11, № 1, P. 111.

91. Vostrikov V.A., Vostrikova N.M. Studying the process of utilization of combined-cycle sulfur compounds to elemental sulfur // Proceedings of Higher Education. Non-ferrous metallurgy, 2006, № 2. - P. 4-8

92. Denisova I.A. Ferritized polyoxide catalyst for the environmental technology of sulfuric acid / N.A. Popov, V.V. Gutenov, I.A. Denisova // Ecology of the urbanized territories. - 2007. - № 3. - P. 13-21.

93. Chan W., Lat-Leung S.Y., Ding J., Ng C. J. Polym. Sci. A, Polym. Chem., 1995, v. 33, N 15. - P.252. 
94. Miyatake K., Jikei M., Katon J. e.a. Polymers Adv. Technol., 1994, v.5. - P. 216.

95. Savin E.D, Nedelkin V.I, Zverev D.V. High-molecular compounds, 1997, v. 39, № 8 - P. 1412-1419.

96. Vardanyan R.S. 4-N-substituted piperidines (review) // Pharmaceutical Chemistry Journal. - 1983. - № 5. - P. 540-541.

97. Yakhontov L.I., Yachenko S.V., Rubtsov M.V. Synthesis of 4-aminopiperidine // ZHOH. - 1958 - V.28, no. 11 - P. 3115-3119.

98. Mobio I.G. Synthesis and transformations of aryl-substituted 4-oxo (hydroxy, hydroxyamino, amino) piperidines. Diss. cand. chemical. Sciences. - M., 1990. - 123 p.

99. Coutts R.T., Casy A.F. Pyridines and reduced pyridines of pharmacologicalinterest in heterocyclic compounds // Suppl To. - 1975. - V. 14, n 4. - P. 446.

100. Nakanishi K. The infrared spectra and structure of organic compounds. - M.: Mir, 1965. -209 p.

101. Guidelines for the definition of toxic properties, used in veterinary medicine and animal husbandry. - Moscow. $-1988-41 \mathrm{p}$.

102. Sokolova M.G., Akimova G.P., Boiko A.V., Nechayev L.V., Glyanko A.K., Vajshlja O.B., Vedernikova A.A. Influence of bacterial biological products on the potato crop and its quality // Agrochemistry, 2008. № 6. - P. 62-67.

103. Putyrsky I.N., Prokhorov V.N., Rodionov P.A. Potatoes. - M.: Makhaon, 2000. - 96 p.

104. Succinic acid in medicine, food industry, agriculture: Collection of scientific works / Edited Kondrashova M.N. - Pushchino: Pushchino Research Center of Russian Academy of Sciences, 1996. - 300 p.

105. The regulation of growth, development and productivity of plants // Proceedings of 3rd Intern. Research. Conf. - Minsk, October 8-10, 2003 Minsk, 2003. - 266 p.

106. Prusakova L.D., Malevannaya N.N., Belopukhov S.L., Vakulenko V.V. Plant growth regulators with anti-stress and immunoprotektornymi properties. // Agrochemistry, 2005, № 11. - P. 76-86.

107. Ahmedova A.I. Influence of growth promoters ASA on yield and quality of potatoes // Bulletin of Agricultural Sciences of Kazakhstan, 1972, № 4. - P.9-14.

108. Peresypkin V.F. Agricultural Phytopathology. - M.: Agropromizdat, 1989. $-480 \mathrm{p}$. 
109. Keldysh M.A., Pomazkov Y.I. Viruses, viroids and mycoplasma plant. Ouch. Allowance. - M.: Publishing House of the Russian Peoples Friendship University, 2003. - 157 p.

110. Kolushpaeva A.T. Using the aldehyde of waste as secondary raw materials // Bulletin KazNTU, 2007, № 2. - P. 99-103

111. Sanin S.S., Cherkashin V.I., Nazarova L.N. Phytosanitary examination of crops (plant disease). - M.: Rosinformagroteh, 2002. -138 p.

112. Shapovalov A.A., Zubkova N.F. Domestic plant growth regulators // Agrochemistry, 2003. № 11. - P. 33-47.

113. Diagnosis of plant resistance to stresses. - L.: WIR, 1988. $-227 \mathrm{p}$.

114. Scandalios J.G. Oxygen stress and superoxide dismutases // Plant Physiol. 1993. V. 101. - P.7-12.

115. Kadyrov S.V., Fedotov V.A. Technology of programming harvests in the CCR. - Voronezh, 2005. - $544 \mathrm{p}$.

116. Astakhova N.V., Suvorova T.A., Deryabin A.N., Trunov T.I. Effect parameter amerol- 2000 on morphological parameters and cold resistance of tomato plants. // Agrochemistry, 2010, № 2 - P. 21-25.

117. Kolushpaeva A.T., Uysimbaeva J.T. Disinfestation of soil muddy zinc // Materials of Int. scientific prakt.konf. "Ensuring environmental safety path to sustainable development of Kazakhstan". - Bulletin of Taraz state University 2010 - P. 57-61.

118. Kolushpaeva A.T., Akbasova A.D., Sunakbaeva D.K., Sultanova G.E. Study the biological activity of a mixture of bentonite clay and 1-methyl-4- (2-tiopikolinamino) piperidine // Int. Scient. Conf. "Modern problems innavatsionnyh technologies in education and science. - Shymkent, 2009. - P. 99-103.

119. Kolushpaeva A.T. The antibacterial activity and toxicity of 1-methyl-4- (2-tiopikolinamino) piperidine // Proceedings of the International scientific-practical conference "Modern problems of innovation technologies in education and science" - Shymkent, 2009. - P. 132-135.

120. Recommendations for use of plant growth regulators in agriculture of Ukraine. - Kiev: Agrobiotech, 2001. - 19 p.

121. Mukhin V.D. Prepare vegetable seeds for sowing. // Moscow Worker. -1979 . - № 3. - P. 5-8.

122. Akbasova A.D., Kolushpaeva A.T., Sainova G.A., Sunakbaeva D.K., Akhmetov N.A. Influence of biologically active compounds, piperidine derivatives to clean soil from heavy metals mustard // Bulletin of KazNU. - Almaty. - 2011. - № 2 (48), part 2. - P. 61-64. 
123. Hamburg K.Z., Kulaeva O.N., Muromtsev G.S., Prusakova L.D., Chkanikov D.I. Plant growth regulators / Edited by Muromtseva G.S. - M.: Kolos, 1979. - 246 p.

124. Krasochkin V.T. Beets. - M.: Selhozizdat, 1960. - P. 5-18.

125. Lukatkin A.S., Ovchinnikova O.V. Tsitodef effect of the drug on the growth and cold resistance of heat-loving plants // Agrochemistry. - 2009. № 12. - P. 32-38.

126. Korovin A.I. Plants and extreme temperatures. - L.: Gidrometeoizdat, 1984. $-271 \mathrm{p}$.

127. Levitt J. Responses of plants to environmental stresses. V.I. Chilling, freezing and high temperatures stresses. N.Y.: Acad. Press, 1980. -426 p. 
Scientific publication

Akbasova Amankul

Sainova Gauhar

\title{
GROWTH STIMULANT AGENTS AND BACTERICIDES
}

\author{
Monograph
}

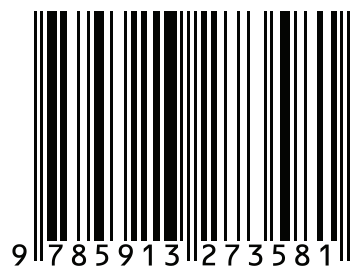

Компьютерный набор, корректура

и форматирование авторов

Технический редактор Кулакова Г.А.

Подписано в печать 23.10.2015

Бумага офсетная.

Гарнитура Times New Roman

Формат $60 \times 841 / 16$

Печать трафаретная. Печ. л. 7,5.

Тираж 500 экз. Заказ № 043-15.

Отпечатано в типографии ИД «Академия Естествознания», 440026, г. Пенза, ул. Лермонтова, 3 